\title{
Nature and timing of Quaternary glaciation in the Himalayan-Tibetan orogen
}

DOI:

10.1016/j.quascirev.2013.11.016

\section{Document Version}

Accepted author manuscript

Link to publication record in Manchester Research Explorer

\section{Citation for published version (APA):}

Owen, L. A., \& Dortch, J. M. (2014). Nature and timing of Quaternary glaciation in the Himalayan-Tibetan orogen. Quaternary Science Reviews, 88, 14-54. https://doi.org/10.1016/j.quascirev.2013.11.016

\section{Published in:}

Quaternary Science Reviews

\section{Citing this paper}

Please note that where the full-text provided on Manchester Research Explorer is the Author Accepted Manuscript or Proof version this may differ from the final Published version. If citing, it is advised that you check and use the publisher's definitive version.

\section{General rights}

Copyright and moral rights for the publications made accessible in the Research Explorer are retained by the authors and/or other copyright owners and it is a condition of accessing publications that users recognise and abide by the legal requirements associated with these rights.

\section{Takedown policy}

If you believe that this document breaches copyright please refer to the University of Manchester's Takedown Procedures [http://man.ac.uk/04Y6Bo] or contact uml.scholarlycommunications@manchester.ac.uk providing relevant details, so we can investigate your claim.

\section{OPEN ACCESS}




\section{Highlights}

- Evidence for Himalayan-Tibetan Quaternary glaciation is reviewed and evaluated

- Numerical dating methods used to define timing of glaciation are evaluated

- Strong regional contrasts in timing and extent of glaciation occur across the orogen

- Glaciation influenced by Asian monsoon, mid-latitude westerlies and topography

- Recommendations made to help advance future Himalayan-Tibetan glacial research 


\section{Nature and timing of Quaternary glaciation in the Himalayan-Tibetan}

2 orogen

4 Lewis A. Owen ${ }^{\mathrm{a}}$ and Jason M. Dortch ${ }^{\mathrm{b}}$

$6{ }^{a}$ Department of Geology, University of Cincinnati, Cincinnati, OH 45221, USA

$7 \quad{ }^{\mathrm{b}}$ School of Environment and Development, The University of Manchester, MO 1QD, UK

9 ABSTRACT

10 Much effort has been made in recent years to define the timing and extent of Quaternary

11 glaciation throughout the Himalayan-Tibetan orogen. These studies are challenging

12 because of the logistical and political inaccessibility of the region, and the inherent

13 problems associated with the application of numerical dating techniques. Nevertheless,

14 the studies are providing abundant evidence for significant glacial advances throughout

15 the last several glacial cycles and are beginning to accurately define the extent and timing

16 of glaciation in selected regions. Studies are showing that Himalayan-Tibetan glaciers in

17 arid regions during the last glacial cycle reached their maximum extent early in the cycle

18 and that global Last Glacial Maximum glacier advances were significantly less extensive.

19 However, along the more monsoonal-influenced Greater Himalaya, there is increasing

20 evidence to suggest that glaciation was more extensive later in the last glacial cycle, but

21 this has yet to be fully assessed. In addition, the new studies are showing that throughout

\footnotetext{
* Corresponding author.

E-mail address: Lewis.Owen@uc.edu (L.A. Owen)
} 
22 most Himalayan-Tibetan regions, significant glacier advances occurred during the Late

23 Glacial and early Holocene, with minor advances in some regions during the mid-

24 Holocene. The still relatively poor chronological control in the Himalayan-Tibetan

25 orogen, however, makes it difficult to construct correlations across the region, and with

26 regions elsewhere in the world. This in turn makes it hard to assess the relative

27 importance of the different climatic mechanisms that force glaciation across the

28 Himalayan-Tibetan orogen, and to quantify paleoclimate change in this high altitude

29 subtropical region. The Late Glacial and Holocene glacial records, however, are

30 particularly well preserved in several Himalayan-Tibetan regions. Glacial successions

31 such as these have the greatest potential to be examined in detail using newly developing

32 numerical dating, and geomorphic and sedimentologic methods to derive high-resolution

33 terrestrial records of glaciation that will help in paleoclimatic reconstruction for high

34 altitude subtropical regions.

35

36 Keywords: Himalaya; Tibet; diamicts; glaciers; radiocarbon dates; cosmogenic dating;

37 OSL dating; Asian monsoon; mid-latitude westerlies

39 1. Introduction

40 The mountains of the Himalayan-Tibetan orogen are the highest on Earth and the orogen

41 is the most glaciated region outside of the polar realms (with $\sim 126200 \mathrm{~km}^{2}$ glacier

42 cover; Haeberli et al., 1989). Glaciers in Himalayan and Tibetan mountains are the source

43 for numerous rivers that flow across the Indo-Gangetic Plain and central and eastern

44 China, which provide freshwater to billions of people. Furthermore, the Himalayan- 
45 Tibetan orogen has a profound influence on regional and global atmospheric circulation

46 and it is therefore important for understanding the dynamics of global environmental

47 change (Ruddiman \& Kutzbach 1989; Molnar \& England 1990; Prell \& Kutzbach 1992;

48 Owen et al. 2002d). The study of glaciation in the Himalayan-Tibetan orogen is also

49 important for providing a framework to examine glacial controls on the development of

50 topography, conditioning landscapes in mountain systems and focusing erosion in them,

51 and governing tectonic feedbacks to the evolution of mountains (Brozović et al., 1997,

52 Zietler et al., 2001; Norton et al., 2010, Willett, 2010). Contention exists over the rate at

53 which glaciers are currently receding to the extent that erroneous estimates have

54 suggested that they are receding faster than in any other part of the world and are likely to

55 disappear by at least the AD 2035 (Intergovernmental Panel on Climate Change, 2007;

56 Bagla, 2009). Impressive glacial landforms and successions of Quaternary glacial

57 sediments are abundant throughout the orogen, recording the nature and style of glacial

58 oscillations.

60 Yet despite the importance of the region and its potentially useful geologic archive, the

61 nature and dynamics of Himalayan-Tibetan glaciers throughout the Quaternary are not

62 well understood. In particular, the timing and extent of past glacier fluctuations are

63 poorly defined. This is partially because the logistical and political inaccessibility of the

64 region has made research there particularly challenging. Nevertheless, the region has had

65 a long history of glacial research, but the older studies were quite restricted in extent

66 because of the logistical and political difficulties. Notably significant historical studies

67 include those of Drew (1873), Dainelli (1922, 1934, 1935), Norin (1925), Klute (1930), 
68 Trinkler (1930) and De Terra and Paterson (1939). In recent years, numerous researchers

69 have undertaken detailed studies of the region's Quaternary glacial geology aided by

70 better accessibility, newly developing remote sensing technologies and numerical dating,

71 and a renewed interest in the region and its glaciers. This has resulted in a plethora of

72 publications that are beginning to allow us to develop a dynamic picture for the

73 Quaternary glaciation of the Himalayan-Tibetan orogen.

74

75 The aim of this manuscript is to present a review of the Quaternary glacial geology of the

76 Himalayan-Tibetan orogen and to speculate on the role of climate and other forcing

77 factors on glaciation in the region. Our manuscript builds on reviews by Shi et al. (1986),

78 Derbyshire et al. (1991), Benn and Owen (1998), Lehmkuhl and Owen (2005), Owen et

79 al. (2008a), Owen (2009, 2013), and regional syntheses in Elhers et al. (2004, 2011),

80 Dortch et al. (2013), Murari et al (2013), and notably, Kamp and Owen (2011), Owen

81 (2011) and Zhou et al. (2011).

82

\section{2. The Physical Environment}

84 The Himalayan-Tibetan orogen is a consequence of the collision of island arcs with the

85 Eurasian continental plate, and the collision of the Indian and Eurasian continental plates

86 at $\sim 50 \mathrm{Ma}$ and the subsequent continued northward movement of the Indian plate at $\sim 50$

$87 \mathrm{~mm} / \mathrm{a}$ (Yin and Harrison, 2000; Searle and Richard, 2007). This has resulted in a

88 mountain mass made up of several approximately east-west trending ranges, with a

89 combined average elevation of $~ 5000 \mathrm{~m}$ asl (Fielding, 1996), composed of a complex

90 assemblage of rocks of different ages. The Himalayan-Tibetan orogen now stretches 
$912000 \mathrm{~km}$ and $\sim 1500 \mathrm{~km}$ in an east-west and north-south direction, respectively, the main

92 ranges comprising, from south to north, the Siwaliks, Lesser Himalaya, Greater

93 Himalaya, Transhimalaya, Nyaingentanglha Shan, Tanggula Shan, Bayan Har Shan,

94 Kunlun Shan, Altun Shan and Qilian Shan. In addition, the active mountains of the

95 Pamir, Tian Shan and Altai Mountains are also part of the orogen (Fig. 1). However, we

96 do not discuss the Altai Mountains in this paper as we do not consider them contiguous

97 with the main mountain mass, and so these regions are beyond the scope of this paper.

99 The mid-latitude westerlies and the south Asian monsoon are the two dominant climatic

100 systems influencing the region (Benn and Owen, 1998; Fig. 2). As Lehmkuhl and Owen

101 (2005), Owen and Benn (2005), Owen et al. (2008a) and Owen (2009) highlight,

102 numerous studies have attempted to link long-term (thousands of years) variations in

103 these climatic systems, influenced by changes in Northern Hemisphere insolation, and

104 shorter-term variations (years to decades), explained by changes within the climate

105 system, to mountain glacier fluctuations throughout the Quaternary.

107 The two climatic systems vary spatially with the majority of the southern and eastern

108 regions experiencing a pronounced summer precipitation maximum, reflecting moisture

109 advected northwards from the Indian Ocean by the southwest monsoon. Summer

110 precipitation declines sharply northward across the main Himalayan chain and is very

111 low over western Tibet (Benn and Owen, 1998; Owen, 2009). The mid-latitude westerlies

112 produce a winter precipitation maximum on the western end of the Himalaya,

113 Transhimalaya and western Tibet as a consequence of moisture being advected from the 
114 Mediterranean, Black, and Caspian Seas (Benn and Owen, 1998; Owen, 2009). These

115 climate systems produce strong north-south and west-east precipitation gradients, as

116 illustrated in Figure 3, ranging, for example, from one of the wettest places on Earth, the

117 East Khasi Hills (with average annual precipitation $>12 \mathrm{~m}$ ) to one of the driest, the

118 hyperarid Takla Makan Desert; these gradients strongly influence the rate of a variety of

119 surface processes including mass movements, fluvial incision, alluvial fan deposition,

120 and glaciation (Bookhagen et al., 2005; Bookhagen and Burbank, 2006; Dortch et al.,

121 2011a). There are also strong microclimatic variations within individual mountain ranges

122 and valleys, potentially exerting strong controls over glaciation (Böhner, 2006; Dortch et

123 al., 2011b). Benn and Owen (1998) hypothesized that the relative role of the two

124 dominant climate systems, the south Asian monsoon and mid-latitude westerlies, varied

125 significantly throughout the Quaternary, resulting in asynchronous glaciation across the

126 orogen. Trying to test this hypothesis has resulted in numerous studies in recent years,

127 which will be discussed in more detail below.

128

129 Vegetation varies as a consequence of climate and altitude from thick subtropical forests

130 in the foothills of the Himalaya and SE Tibet to deciduous forests at higher altitude and

131 eventually alpine meadow and mountain tundra at the highest elevations with xerophytic

132 vegetation in the arid interiors of the orogen. The equilibrium-line altitudes (ELAs) for

133 glaciers across the orogen vary considerably as a consequence of the different roles of the

134 two main climatic systems and the precipitation gradients, for example, ranging from

$1354300 \mathrm{~m}$ asl in southeast Tibet to over $6000 \mathrm{~m}$ asl in western Tibet (Owen and Benn,

136 2005). Benn and Lehmkuhl (2000) and Owen and Benn (2005) describe the controls on 
137 mass balance and variation of present and past ELAs through the Himalaya and Tibet.

138 Owen and Benn (2005) highlight that the present regional ELA varies in altitude across

139 ranges; for example, it is 4600-5700 to 6000-6200 m asl south to north across Mount

140 Everest, 5200-5700 m asl south to north across the Garhwal Himalaya, 4500-4700 m asl

141 around Nanga Parbat, and 4600-5300 to 5200-5700 m asl south to north across the

142 Karakoram Mountains.

143

144 Climate and topography have a strong influence on the nature of glacial systems

145 throughout the Himalayan-Tibetan orogen. In essence, glacial systems are highly

146 variable. Derbyshire (1982) divided the glaciers into three main types: 1) continental

147 interior types in the central and western parts of the Tibet Plateau; 2) maritime monsoonal

148 types in the Himalaya and in southeastern Tibet; and 3) continental monsoonal types in

149 eastern and northeastern Tibet (Fig. 4). As Owen and Benn (2005) point out, most

150 glaciers within the region occupy steep, high relief catchments, and have cold, high

151 altitude (> $5000 \mathrm{~m}$ asl) accumulation areas. Where mass turnover is high, or where debris

152 cover allows glaciers to descend to lower altitudes, ablation zones may be temperate

153 whereas glaciers located in dry high altitude environments are cold throughout. Annual

154 temperature cycles vary with the degree of continentality, altitude and insolation.

155

156 The maritime and continental monsoonal glaciers of the Himalaya and southeastern and

157 eastern Tibet are warm-based and have summer accumulation and ablation; they are also

158 highly diverse, including avalanche- and snowfall-fed cirque and valley glaciers, and

159 very steep hanging glaciers (Derbyshire, 1981; Benn and Lehmkuhl, 2000; Benn and 
160 Owen, 2002). Benn and Owen (2002) emphasized that snow avalanching from

161 precipitous slopes forms an important component of accumulation on many of these

162 glaciers, and glacier ablation areas can be separated from source areas by steep icefalls or

163 avalanche tracks. These are usually high activity glaciers that may have velocities up to

164 several hundred meters per year (e.g. Seong et al., 2009d). Basin topography, therefore,

165 plays an important role in determining the geometry and mass balance of these

166 monsoonal glaciers.

168 Alpine continental glaciers in the western part of the orogen (Transhimalaya, Pamir, and

169 Tian Shan) are significantly smaller than their monsoonal counterparts and are generally

170 low flux due to an annual precipitation typically $<1000 \mathrm{~mm}$ combined with high and

171 cold accumulation areas. In spite of this, they produce landforms (roche moutonnées and

172 large moraines) indicating mixed based if not warm based conditions at times (Koppes et

173 al., 2008; Dortch et al. 2010, 2011b,c; Röhringer et al., 2012). In contrast, the continental

174 ice caps of central and western Tibet have basal ice temperature $\ll 0^{\circ} \mathrm{C}$ and they have an

175 annual precipitation « 1000mm (at altitudes > $5000 \mathrm{~m}$ asl). The Guilya icecap, for

176 example, has an ice temperature of $-18^{\circ} \mathrm{C}$ and has an annual precipitation of $300-400 \mathrm{~mm}$

177 (Shi, 2002). Shi (2002) noted that these continental glaciers are similar to sub-polar types,

178 with low surface velocities, usually between 2 and $10 \mathrm{~m} / \mathrm{a}$, and may extend outside the

179 permafrost zone. In addition, these glaciers are usually less topographically constrained

180 and generally have limited debris cover compared to those in the Himalaya (Owen and

181 Benn, 2005). 
183 Benn and Owen (2002) provided a review of Himalayan glacial sedimentary systems,

184 describing the complexity of associated landform and lithofacies, and the importance of

185 erosional, depositional and deformational processes. They showed that many Himalayan

186 glaciers have extensive mantles of supraglacial debris on their ablation zones, whereas

187 others have little or no supraglacial debris; a spectrum of glacier types exists between

188 these end members. Benn and Owen (2002) reasoned that the amount of debris cover on

189 glacier surfaces is controlled by a number of factors, the most important of which is the

190 distribution of steep slopes in the glacial catchment from which avalanches can deliver

191 rock debris, either from bedrock or pre-existing glacial and paraglacial sediments. Other

192 factors influencing debris cover include: (1) precipitation, which governs the amount of

193 snowfall relative to rock inputs, and hence the debris concentration on the ice; (2) glacier

194 size (long valley glaciers are most likely to have extensive debris mantles); and (3)

195 bedrock erodibility (resistant, massive rocks such as granite will yield much less debris

196 than highly fractured schists and sedimentary rocks). The abundance of supraglacial

197 debris helps produce complex latero-frontal moraines that may record one or more glacial

198 oscillations (Figs. 4D and E). Other important studies of the glacial sedimentary system

199 include those of Derbyshire (1981, 1982, 1984, 1986), Li et al. (1984) and Owen and

200 Derbyshire (1989).

201

202 Supraglacial debris may be so dominant in some glaciated catchments that morainic rock

203 glaciers develop (Owen and England, 1998; Fig. 4F). Protalus rock glaciers may also

204 form in permafrost regions (Owen and England, 1998; Fort, 2003; Iwata et al., 2003).

205 Owen and England (1998) showed that, in the Karakoram and Himalaya of Northern 
206 Pakistan and India, morainic and protalus rock glaciers are restricted altitudinally and

207 climatically to sites above $\sim 4000 \mathrm{~m}$ asl and in regions where annual precipitation is <

$2081000 \mathrm{~mm}$. Generally in these regions, morainic rock glaciers are large, usually $>1 \mathrm{~km}$

209 long, > $100 \mathrm{~m}$ wide and > $15 \mathrm{~m}$ thick. Owen and England (1998) suggested that morainic

210 rock glaciers record the advance of ice-cored moraines following retreat of glaciers,

211 likely since the Little Ice Age.

212

\section{3. Reconstructing past glaciations in the orogen}

214 Many researchers throughout the twentieth century and increasingly over the last few

215 decades have reconstructed the extent of Late Quaternary glaciation throughout the

216 Himalayan-Tibetan orogen. Important compilations and reconstructions of glaciation

217 throughout the orogen include those of Klute (1930), Frenzel (1960), Li et al. (1991) and

218 Shi (1992), which show expanded ice caps and extensive valley glaciers (Fig. 5). The

219 studies of Klute (1930) and Frenzel (1960) are remarkable given the limited studies that

220 were available to these researchers. The most recent reconstructions by Li et al. (1991)

221 and Shi (1992) represent an impressive compilation of studies and are in general

222 agreement with most recent research showing alpine-style glaciation throughout the

223 region during the last few glacial cycles. Numerous field studies provide regional maps of

224 reconstruction (e.g. Porter, 1970; Derbyshire et al., 1984; Cronin et al., 1989; Holmes and

225 Street-Perrott, 1989; Watanabe et al., 1989; Shiraiwa and Watanabe, 1991; Lehmkuhl and

226 Lui, 1994; Osmaston, 1984; Owen et al., 1995, 1996, 1997, 2000; Taylor and Mitchell,

227 2000; Lehmkuhl et al., 2004; Heyman et al., 2010, 2011). Most recently, remote sensing

228 has enabled very impressive glacial geologic maps to be reconstructed, notably by 
229 Duncan et al. (1998), Heyman et al. (2008) and Moren et al. (2011).

231 In contrast to most studies, Kuhle (1985, 1986, 1987, 1988a,b, 1990a,b, 1991, 1993,

232 1995) argued for an extensive ice sheet covering most of the Tibetan Plateau during the

233 Last Glacial. However, much evidence has been presented against the possibility that an

234 extensive ice sheet could have existed across Tibet during the last $500 \mathrm{ka}$ (Derbyshire,

235 1987; Burbank and Kang, 1991; Derbyshire et al., 1991; Shi et al., 1992; Hövermann et

236 al., 1993a,b; Lehmkuhl, 1995, 1997, 1998; Rutter, 1995; Lehmkuhl et al., 1998; Zheng

237 and Rutter, 1998; Schäfer et al., 2002; Owen et al., 2003a, 2008a; Seong et al., 2008;

238 Dortch et al. 2013). In particular, Lehmkuhl et al. (1998), Owen et al. (2008), Seong et

239 al. (2008), and Owen (2010) argue that Kuhle's (1985, 1986, 1987, 1988a,b, 1990a,b,

$2401991,1993,1995)$ reconstructions likely differ from other researchers because of his

241 misinterpretation of landforms and sediments, the misuse of ELAs for defining former ice

242 extent, and poor chronological control. Specifically, numerical dating that has been

243 undertaken in Tibet shows that moraines for the majority of the most extensive glacial

244 advances formed early in the Last Glacial, the penultimate glacial cycle or much earlier,

245 proving that an ice sheet could not have existed during the Last Glacial, otherwise the

246 moraines would have been destroyed. In an attempt to try to reconcile this evidence with

247 his model for an ice sheet over Tibet, in contrast to all the other research being

248 undertaken with radiocarbon, OSL and TCN dating in the Himalayan-Tibetan orogen and

249 other high mountain regions, Kuhle (2011) dismisses numerical dating, arguing that

250 numerical dating cannot be applied at high altitudes as it is at lower elevations. He argues

251 that all radiometric ages need calibrating to make ages $1 / 6^{\text {th }}$ or $83 \%$ younger than 
252 published ages to fit his ice sheet model. However, his conversion factor arguments are

253 spurious, there being no validity to his suggestions. Ironically, this now resolved

254 controversy with Kuhle $(1985,1986,1987,1988 a, b, 1990 a, b, 1991,1993,1995)$ has left

255 the idea for an ice sheet over Tibet firmly out of favor but it may have been possible,

256 although highly unlikely, for an ice sheet to form over Tibet during the early- to mid-

257 Quaternary. Surficial glacial landforms of this period have not been identified, but

258 further insight might come from marine and lake core stratigraphy.

260 Clearly, accurate reconstructions of former glacial extent rely on the sound interpretation

261 of landforms and sediments as well as geochronology. In particular, researchers such as

262 Derbyshire (1983, 1996), Owen and Derbyshire (1988), Fort (1986), Fort and Derbyshire

263 (1988), Derbyshire and Owen (1990, 1997), Hewitt (1998, 1999), Benn and Owen (2002)

264 and Hewitt et al. (2011), have warned of the dangers of misinterpreting glacial and mass

265 movement landforms in the Himalaya and Tibet. Large landslides are common

266 throughout the Himalayan-Tibetan orogen and their forms can often resemble moraines

267 (Fig. 6). In addition, a continuum of landforms including moraines, rock glaciers, talus

268 slopes and landslides exists that exacerbates the problems of distinguishing landform

269 types (Owen, 1991; Fort, 2003). Moreover, intense fluvial and glacial erosion often

270 destroys diagnostic morphologies of glacial and mass movement landforms, making their

271 identification difficult (Owen, 1991; Benn and Owen, 2002). Furthermore, the diamictons

272 that comprise mass movement and glacial landforms look very similar and have similar

273 particle size distributions and particle shapes. All this makes it very challenging to

274 identify landforms and sediments correctly unless sediments are examined with due care. 
276 Hewitt $(1998,1999)$ and Hewitt et al. (2011) provide important examples from the

277 Karakoram of Northern Pakistan where landslides have been misidentified as moraines

278 (Fig. 7). Unfortunately, few papers provide detailed descriptions of the landforms and

279 sediments that are used to reconstruct former glacier extents. This makes it difficult to

280 fully access the validity of many of the reconstructions. Benn and Owen (2002) provide a

281 useful overview to help researchers recognize the problems associated with identifying

282 landforms and sediments in Himalayan environments and suggest approaches to

283 accurately interpret the glacial geomorphic and sedimentological evidence.

285 Most detailed reconstructions of former glacial extents within individual study areas

286 apply standard morphostratigraphic methods similar to those outlined in Rose and

287 Menzies (1995). In essence, glacial and associated landforms are mapped, based on their

288 morphostratigraphic positions and the relative weathering of their forms and surfaces in

289 each detailed study area. Often this is made easy because large relief within a landscape

290 helps to separate moraines of different glacial advances at different altitudinal positions.

291 Relative dating methods have included the use of soil development (Guggenberger et al.,

292 1998; Bäumler et al., 1999; Zech et al., 2000), and weathering characteristics and rock

293 varnish development (Owen et al., 1996, 1997; Waragai, 1998, 2005). Commonly,

294 researchers will assign a glacial stage name to a particular suite of glacial and associated

295 landforms that they recognize to have formed during a distinct glacial advance (e.g.

296 Derbyshire et al., 1984; Burbank and Fort, 1985; Seong et al., 2007; 2009b, Owen et al.,

297 2003, 2012). Some studies provide type locations for a particular glacial stage, which 
298 may be used by future researchers as a basis for comparing and extending the glacial

299 chronologies (e.g. Seong et al., 2009b; Owen et al., 2012). Other studies simply number

300 moraines of different stages (e.g. Zech et al., 2005; Abramowski et al., 2006; Koopes et

301 al. 2008; Hendrick et al., 2011) or provide no number or name at all (e.g. Kong et al.,

302 2009b). Applying glacial stage names or a numbering scheme allows landforms to be

303 tentatively correlated across a study region and between adjacent regions before a

304 quantitative chronostratigraphy has been established; however, correlation based on the

305 number of stages in a sequence without chronology should be undertaken with extreme

306 caution. Most recent studies are applying the approach described by Hughes et al. (2005)

307 to develop formal stratigraphies. Figure 8 shows an example of the morphostratigraphic

308 approach that has been applied to glacial successions within one valley of the Himalayan-

309 Tibetan orogen.

310

311 Once a morphostratigraphy has been developed, it can form the framework for numerical

312 dating to help define the timing of each glacial advance/glacial stage. The application of

313 numerical dating will be discussed in detail in the next section. Detailed mapping is also

314 commonly used to reconstruct the size of former glaciers as a basis for determining

315 former ELAs (Benn and Lehmkuhl, 2000; Benn et al., 2005; Owen and Benn, 2005).

317 4. Dating methods: challenges and advances

318 Much effort has been undertaken in recent years to define the timing of glaciation

319 throughout the Himalaya and Tibet but, until the turn of the millennium, few studies

320 presented numerical ages for glacial successions in the Himalayan-Tibetan orogen. 
321 Gillespie and Molnar's (1995) review of the timing of mountain glaciation throughout the

322 world, and its asynchronousity with continental glaciers, highlighted the paucity of data

323 for the Himalayan-Tibetan region. Similarly, Benn and Owen's (1998) review and

324 speculation on the relative roles of the summer monsoon and mid-latitude westerlies in

325 driving Himalayan-Tibetan glaciation emphasizes the dearth of numerical ages.

326

327 The former lack of numerical ages mainly resulted from a scarcity of organic material

328 needed for radiocarbon dating in most regions. Where organic material was present,

$32995 \%$ (142 of 149) of ages were limited to the Holocene. This is illustrated by the

330 compilation of radiocarbon dating we present in Table 1 and Figure 9.

332 Röthlisberger and Geyh (1985a,b, 1986) undertook an extensive study using radiocarbon

333 dating (including 68 radiocarbon ages). They examined eight different regions throughout

334 the Himalaya and Karakoram of Pakistan, India and Nepal to show that glaciers had

335 undergone at least 11 advances since the global Last Glacial Maximum (LGM) (Fig. 9A).

336 However, only relatively modest studies have been undertaken using radiocarbon dating

337 since the work of Röthlisberger and Geyh (1985a,b, 1986). Most studies have dated

338 charcoal or wood (e.g. Benedict, 1976; Fushimi, 1977, 1978; Derbyshire et al., 1984;

339 Geyh et al., 1985; Röthlisberger and Geyh, 1985a,b; Zheng and Li, 1986; Wang and Fan,

340 1987; Zhang, 1988; Zheng and Ma, 1994; Chinese Academy of Sciences, 1996; Narama,

341 2002; Su et al., 2002; Meyer et al., 2007; Lee et al. 2013), but many have used humic

342 matter (Li and Jiao, 1990; $\mathrm{Li}$ and Li, 1992; Jiao and Iwata, 1993; Zheng et al., 1995;

343 Iwata and Jiao, 1993; Owen et al., 1997; Iwata et al., 2002; Jiao et al., 2005; Zheng, 
344 2006; Jiao and Zheng, 2006). Carbonate precipitates have also been dated but these are

345 subject to large uncertainties because of hardwater effects; also the carbonates may have

346 developed significantly later than the formation of the landform that is being dated

347 yielding very minimum ages (e.g. Mann et al., 1996; Yi et al., 2004).

348

349 Yi et al. (2008) reviewed much of the radiocarbon dating Holocene glacial chronologies

350 for Tibet and the surrounding mountains. They compiled 58 ages, but notably omitted the

351 studies of Röthlisberger and Geyh (1985a,b, 1986). In addition, Yang et al. (2008)

352 reviewed the radiocarbon dating undertaken to establish the Late Holocene monsoon

353 temperate glacier fluctuations on the Tibetan Plateau. Building on these compilations, we

354 compile the radiocarbon ages for studies throughout the Himalayan-Tibetan orogen and

355 present these in Table 1 and Figure 9. We plot minimum radiocarbon ages, i.e., ages that

356 are younger than the age of the moraine that is being dated, which are then used to

357 calculate a probability distribution density graph. This allows us to determine whether

358 these age data define the timing of glacial oscillations throughout the Late Quaternary,

359 since the peaks of the probability distributions likely represent revegetation of the glacial

360 foreland, which is assumed to approximate the time of deglaciation. The frequency of

361 peaks is similar to those of the Holocene rapid climate change as suggested by Mayewski

362 et al. (2004). However, this similarity relies on the assumption that glaciations dated by

363 radiocarbon methods are synchronous throughout the orogen. This assumption needs to

364 be tested in future radiocarbon-based studies by targeting Holocene landforms in several

365 climatic regions of the orogen. 
367 Following the significant developments in OSL and TCN surface exposure dating during

368 the 1990s and early 2000s, numerous researchers began to apply these methods

369 throughout the Himalayan-Tibetan orogen. OSL methods were applied before TCN

370 methods, initially using thermoluminescence (TL; e.g., Derbyshire et al., 1984). The first

371 extensive program of OSL dating in the Himalaya was undertaken by Richards (1999)

372 resulting in detailed studies in the Khumbu Himal, Nepal (Richards et al. 2000b), and the

373 Swat and Nanga Parbat regions in Northern Pakistan (Richards et al. 2000a). Other

374 significant studies using OSL include those of Tsukamoto et al. (2002) in the

375 Kanchenjunga Himalaya, Derbyshire et al. (1984) and Spencer and Owen (2004) in the

376 Hunza valley of northern Pakistan, Narama et al. (2007) in the Terskey Alatoo Range

377 (Kyrgyz Republic), and Narama et al. (2009) and Zhoa et al. (2012) in the Tien Shan.

378 Richards (2000) discusses the problems associated with the application of OSL methods

379 in the Himalaya, which include those associated with inadequate bleaching of sediment

380 and low luminescence signals (see Fuchs and Owen (2008) for more details about OSL

381 dating of glaciogenic sediments). Table 2 summarizes the OSL dating studies that have

382 been undertaken throughout the Himalayan-Tibetan orogen.

383

384 Another potentially important technique, electron spin resonance (ESR) dating has been

385 undertaken in a few areas (e.g. Wu et al., 2001; Zhao et al., 2009, 2012). Researchers

386 using ESR contend that the ESR signal is reset in till by pressure during glacial grinding.

387 However, there is much contention over whether this mechanism can fully reset the ESR

388 signal and, as such, ESR ages should be considered very conservatively. 
390 Arguably, TCN dating has been applied more to the Himalayan-Tibetan glacial

391 successions than any other glaciated mountain region in the world. Currently, for

392 example, there are $>1700{ }^{10} \mathrm{Be}$ ages on moraine boulders in addition to numerous

393 glacially eroded bedrock surfaces, plus boulder ages and depth profiles on associated

394 landforms. Table 3 and Appendix 1 list the ${ }^{10} \mathrm{Be}$ ages for chronologies throughout the

395 Himalayan-Tibetan orogen. Most TCN studies use ${ }^{10} \mathrm{Be}$ for dating, but ${ }^{26} \mathrm{Al}$ has also been

396 applied, usually on the same sample that is being dated with ${ }^{10} \mathrm{Be}$ (e.g. Owen et al., 2001,

397 2002a, 2003b,c; Schäfer et al., 2002; Tschudi et al., 2003). In addition, ${ }^{3} \mathrm{He}$ and ${ }^{21} \mathrm{Ne}$ have

398 been applied in several studies (Tschudi et al., 2003; Gayer et al., 2006; Graf et al., 2008;

399 Schäfer et al., 2008; Strasky et al., 2009).

400

401 Problems associated with the application of TCN methods to date moraines in the

402 Himalaya, Tibet and elsewhere, have been discussed in depth in numerous studies (e.g.

403 Hallet and Putkonen, 1994; Benn and Owen, 2002; Owen et al., 2002a, 2003a,c, 2005,

404 2006a,b, 2008a, 2009, 2010, 2012; Putkonen and Swanson, 2003; Putkonen and O’Neal,

405 2006; Seong et al., 2007, 2008, 2009a; Putkonen et al., 2008; Dortch et al. (2010b);

406 Chevalier et al., 2011; Heyman et al., 2011b). In particular, Owen et al (2008) highlighted

407 the uncertainty introduced when calculating TCN ages for Himalayan and Tibetan glacial

408 successions using different scaling models and that this may result in ages that differ by

409 as much as 30\% using 777 ages (see Figs. 5 and 6 in Owen et al., 2008). Here, updated

410 plots including the now $>1700$ published ages from the orogen show that ages from

411 various researchers differ by up to 40\% from recalculated Lal (1991) - Stone (2002)

412 time independent ages (CRONUS Calculator Version 2.2; Fig. 10A). We highlight this 
413 to illustrate the problems with using published data at face value. Moreover, as Balco et

414 al. (2008) points out, the greatest difference between ages calculated by the different

415 scaling models are those for low latitudes and high altitudes, which encompasses the

416 Himalaya-Tibetan orogen. The resulting differences can be seen in Figure 10B, where

417 percent difference after using Lifton et al. (2005), Desilets et al, (2003, 2006), Dunai

418 (2001), and Lal (1991) - Stone (2000) time dependent scaling schemes have been plotted

419 with respect to Lal (1991) - Stone (2002) time independent ages. These large differences

420 present challenges when comparing TCN ages with radiocarbon, OSL, and other

421 numerical age methods, as well as climatic records. The accuracy of the reference sea

422 level, high-latitude (SLHL) ${ }^{10}$ Be productions rate has been challenged by the regional

423 rates of Balco et al. (2009), Putnam et al. (2010), Fenton et al. (2011), Kaplan et al.

424 (2011), Briner et al. (2012), and Goehring et al. (2012). The new regional ${ }^{10} \mathrm{Be}$

425 production rates range between 5-15\% lower than SLHL and result in older ages. Figure

426 10C shows the difference in percent between Balco et al. (2009) and Putnam et al. (2010)

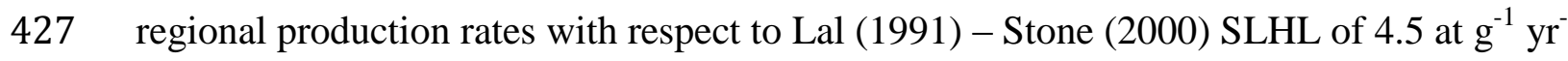

$428{ }^{1}$ time-independent ages. Although these studies show broad agreement, they only cover a

429 limited temporal ( $<15 \mathrm{ka})$ and elevation $(<1500 \mathrm{~m}$ asl) scale and a regional calibration

430 site comparing radiocarbon and TCN methods has not been defined in the Himalayan-

431 Tibetan orogen. Moreover, differences in isostatic rebound, air-pressure, and differing

432 paleomagnetic field effects could create significant offsets when extrapolating to

433 dissimilar regions (e.g. Balco et al. 2009). Thus, extrapolation of production rates from

434 calibration sites to high elevation (>4000 m) and old landforms (50-700 ka) should only

435 be undertaken with extreme caution. Moreover, the TCN data used in calibration papers 
436 do not have perfect gaussian distributions; thus, when using the subsequent productions

437 rates, researchers should use the same statistical methods to examine clustering of ages.

438 Unfortunately, there is no scaling scheme or production rate that has been rigorously

439 proven to be the most accurate, leaving researchers free to choose the scheme that they

440 deem best, or best fits their interpretations. Ironically, if carefully chosen, using the

441 combination of new production rates and scaling scheme, $\sim 78 \%(\mathrm{n}=1331)$ of all ages

442 yield results within $10 \%$ of time-independent Lal (1991) - Stone (2000) ages when

443 between 11-700 ka; whereas only 10\% $(n=169)$ of all ages are within $15 \%$ between 5 -

$44411 \mathrm{ka}$ (Fig. 10D). These correction factors do not appear to be quite as significant when

445 taken in the context of normal individual age errors of 5-10\%.

447 Irrespective of these various correction schemes, the geologic error associated with TCN

448 dating and the statistical treatment of ages to identify outliers has a far more significant

449 effect on dating moraines and other landforms. As Hallet and Putkonen (1994), Owen et

450 al. (2008) and numerous other researchers point out, geological factors present the largest

451 uncertainty in applying TCN surface exposure dating methods. These include early

452 stabilization and denudation of the landform, as well as weathering, exhumation, prior

453 exposure and shielding of the surface that is being dated by snow and/or sediment.

454 Generally these processes reduce the concentration of TCNs, resulting in an

455 underestimate of the true age of the landform, with the exception of prior exposure that

456 results in an overestimation of the landform's age. The net result of these processes can

457 be a large spread in apparent exposure ages of individual boulders on a single landform,

458 such as a moraine, or in different positions on an extensive rock surface such as glacially 
459 eroded bedrock. For example, Dortch et al. (2013) show that $40 \%$ of all ages in the

460 western semi-arid part of the orogen are outliers with age underestimation occurring four

461 times more often than inheritance. They show that inherited outliers are $60 \%$ higher than

462 landform age on average, with numerous samples having up to $300 \%$ inheritance, while

463 underestimation diverges from moraine age by an average of $\sim 55 \%$ younger with

464 numerous samples diverging by up to $90 \%$. Due to possible post-processes, researchers

465 typically interpret TCN ages as representing the timing of deglaciation. Researchers

466 usually collect multiple samples on a surface in an attempt to assess these effects. The

467 combined results of Dortch et al. $(2013 ; n=95)$ and Murari et al. $(2013 ; n=208)$ that

468 included the examination of 303 local glacial stages shows that when $\leq 4$ samples are

469 collected, the probability of obtaining three ages that fit a normal distribution is $\sim 27 \%$,

470 but dramatically shifts to at 5 samples to is $\sim 77 \%$, and increases with $\geq 6$ samples to

$471 \sim 98 \%$ (Fig. 11). The basic rationale is that the presence of multiple boulders or surface

472 samples having similar apparent ages is taken as evidence that the boulders were not

473 derived from a range of older surfaces and/or were not weathered, exhumed or covered.

474 Additionally, sequences of landforms are often dated to assess the relative behavior of

475 clustered TCN ages. Hence the ages are then considered to be representative of the true

476 age of the surface. However, it is not common to have strong clustering of ages,

477 particularly for Pleistocene moraines, and the spread of ages is generally greater with 478 antiquity.

479

480 Figure 12 provides an example of a large, reasonably well-clustered data set for a study 481 area within the Himalayan-Tibetan orogen. Each rectangle encloses individual ${ }^{10} \mathrm{Be}$ ages 
482 for a particular glacial stage. Clearly, the clustering of ${ }^{10} \mathrm{Be}$ ages is tightest for the

483 younger glacial stages. The greatest challenge is interpreting the broad spread of ages.

484 Many researchers, including Hallet and Putkonen (1994), Zreda et al. (1994), Putkonen

485 and Swanson (2003), Briner et al. (2005), Zech et al. (2008), Applegate et al. (2010) and

486 Heyman et al. (2011), favor assigning the glacial age based on the age of the oldest

487 boulder (if not an "obvious" outlier) determined for a surface. The oldest boulder method 488 implies that the boulder has been least weathered, shielded or exhumed. However, the

489 oldest age might be a consequence of inherited TCNs. Moreover, the method of

490 determining if a boulder is an "obvious" outlier varies from a simple judgment call to

491 using a non-stringent statistical test (e.g. beyond $2 \sigma$ of the mean of the population). In

492 contrast, the youngest boulder might be considered most representative since it is least

493 likely to have inherited TCNs from former exposure. Putkonen and Swanson (2003) and

494 Heyman et al. (2011) argue that only a small percent of dated moraine boulders have had

495 prior exposure, which lends favor to the oldest boulder method. To reiterate the point,

496 Dortch et al. (2013) caution that $8 \%$ of all glacial boulders dated in the semi-arid western

497 portion of the orogen show inheritance typically ranging from 5-300\% with rarer

498 examples with up to $1200 \%$ of the landform age (for ages $<1-350 \mathrm{ka}$ ) and that outliers

499 are not always obvious. Similar analysis by Murari et al. (2013) supports this view.

500 They show that $10 \%$ of all glacial boulders dated in the monsoon influenced regions of

501 Himalaya and Tibet show inheritance typically ranging from 6-300\% with rare examples

502 exceeding $1000 \%$. To add complication, both studies show that young outliers occur 3-4

503 times more often than inherited outliers and argue that statistical analysis is required to

504 identify the most correct ages. 
506 Numerous researchers suggest statistical analysis of ages, such as applying the mean

507 square of weighted deviates method (MSWD); iterative reduced chi-squared, is more

508 appropriate because it is a much stricter test and easily identifies outliers (e.g. Gosse et

509 al., 1995; Finkel et al., 2003; Meriaux et al., 2004; Chevalier et al., 2005; Owen et al.,

510 2005; Dortch et al., 2010, 2011; Hedrick et al., 2011). However, Ivy-Ochs et al. (2007)

511 argue that using MSWD and the resulting weighted mean unjustly skews ages because

512 younger ages typically have smaller uncertainties. Dortch et al. (2013) separated

513 gaussians from cumulative probability frequency distributions to obtain best fits on TCN

514 data for semi-arid regions at the western end of the Himalayan-Tibetan orogen, which

515 they then used to delimit local glacial stages. Student's t-test was used to correlate TCN

516 age clusters across the region, the results of which will be discussed in more detail below.

517 Clearly, the issue of understanding age data needs to be resolved and care must be taken

518 when considering the ages of glacial events in the Himalayan-Tibetan orogen.

519 Fortunately, most researchers present all their primary data so that future researchers can

520 manipulate published data and make their own interpretations. However, we suggest that

521 studies focused on the timing of glaciation and the links to climatic records should use

522 the Lal (1991) - Stone (2000) time-independent scaling scheme for comparability until

523 geomagnetic correction and SLHL productions rate uncertainties are better constrained

524 and that significant attention needs to be given to developing a standard for the statistical

525 treatment of ages.

527 A strategy taken by some researchers to try to overcome problems with dating is to apply 
528 both OSL and TCN methods within a study area. This has the advantage of providing

529 depositional ages (OSL dating) and deglaciation ages (minimum ages with TCN dating).

530 Benn and Owen (2002) set out possible sampling strategies that might be applied using

531 both OSL and TCN methods, as illustrated in Figure 13. Unfortunately, one of the main

532 limitations of using this strategy is the availability of good exposures of sediment for

533 OSL dating. This strategy has been successfully applied in several regions, most notably

534 in the Khumbu Himal and Rongbuk valley on the south and north sides of Mount Everest,

535 respectively. Figure 14 shows an example of a laterofrontal moraine complex that was

536 dated using both OSL and TCN methods at the Lhotse Nup glacier terminus at Chhukung

537 in the Khumbu Himal (Richards et al. 2000b; Finkel et al., 2003). ${ }^{10}$ Be surface exposure

538 ages on this moraine are between 2.6-3.5 ka whereas an OSL age on the upper sediment

539 unit is $1.1+/-0.2 \mathrm{ka}$, supporting the view that the moraine represents a Late Holocene

540 glacial advance. In this case, the older TCN ages might reflect a thousand or years of

541 prior exposure. Unlike TCN methods, OSL dating also allowed an earlier advance to be

542 defined to the early Holocene $(\sim 10 \mathrm{ka})$ by dating the lower sediment unit at this site.

543 Figure 15 shows the chronologies for the Rongbuk valley, which are well defined by both

$544{ }^{10} \mathrm{Be}$ TCN and OSL dating methods.

545

\section{5. Evidence of extremely old glaciations}

547 There is abundant geomorphic and sedimentological evidence for glaciation predating the

548 penultimate glacial cycle in the Himalayan-Tibet orogen. In some cases moraines are

549 well preserved, especially in the semi-arid regions of Tibet and the Transhimalaya, but in

550 most regions old moraines are denuded. Amongst the oldest moraines are those of the 
551 Indus glacial stage in Ladakh. Owen et al. (2006a) showed these to have been formed

552 when extensive valley glaciers advanced to an elevation below $3250 \mathrm{~m}$ asl; they are dated

553 to $>430 \mathrm{ka}$ (Fig. 16A). Other extremely old moraines are present on the west side of

554 Gurla Mandata in southernmost central Tibet (Fig. 16B). Based on ${ }^{10} \mathrm{Be}$ dating of

555 boulders, Owen et al. (2010) argued that these moraines are considerably older than 300

556 ka and thus likely formed during MIS 10 or during an earlier glacial cycle when ice caps

557 expanded during the Naimona'nyi glaciation. In addition, in the Rongbuk valley on the

558 northern side of Mt Everest, Owen et al. (2009) dated erratics to > $330 \mathrm{ka}$, which they

559 argued formed by extensive valley glaciers advancing northwards from Mount Everest. In

560 the Central Karakoram, Seong et al. (2007) recognized an extensive valley glacier

561 system, which they dated to MIS 6 or older. Other moraines of great antiquity

562 (penultimate or earlier glacial cycle) have been dated using TCN methods by Owen et al.

563 (2006b), Chevalier et al. (2005, 2011), Schäfer et al. (2008) and Hedrick et al. (2011) in

564 the Kunlun Shan, Ayilari Range, Nyalam, Xainza graben in south central Tibet, and the

565 Zaskar, respectively. On Muztag Ata, in the Chinese Pamir, Seong et al. (2009a) showed

566 that ice caps expanded during the Karasu glacial stage, which they dated to the

567 penultimate glacial cycle or earlier using ${ }^{10}$ Be dating. Just south of Muztag Ata in the

568 Tashkurgan valley, Owen et al. (2012) dated moraines of the Dabudaer glacial stage

569 using ${ }^{10} \mathrm{Be}$ to the penultimate glacial cycle and/or earlier (Fig. 16C).

570

571 Using ESR and TL methods, Wu et al. (2001) dated tills of the Wangkun Glaciation on

572 the Kunlun Pass to between 0.7-0.5 Ma. In addition, using ESR methods, Zhao et al.

573 (2001) dated till of the Gaowangfeng Glacial Stage in the headwaters of the Urumqi 
574 River in the Eastern Tien Shan to 400-470 ka, while Zhao et al. (2009) dated till of the

575 Qingshantou Glacial Stage in the Ateaoyinake River Valley of the central Tien Shan to

$576 \sim 440 \mathrm{ka}$. Till of the Zhonglianggan glaciation in the Qilian Mountains was also dated

577 using ESR methods by Zhou et al. (2001, 2006) yielding an age of $\sim 463 \mathrm{ka}$.

578

579 The large uncertainty associated with dating these old moraines and sediments precludes

580 regional correlation. Moreover, it is difficult to correlate convincingly the old moraines

581 within a region. Owen et al. (2012) for example, stated that moraines assigned to their

582 Dabudaer glacial stage in the Tashkurgan valley might represent several glaciations, since

583 the strong degree of weathering of Dabudaer glacial stage landforms does not allow

584 subtle morphostratigraphic distinctions to be made.

585

586 Old moraines (penultimate glacial cycle or older) and sediments in high-precipitation

587 monsoon-influenced Himalayan regions are not as common as for the semi-arid regions,

588 however. This might simply be because the preservation potential for old moraines is low

589 due to intense denudation, mainly by fluvial and mass movement processes, which

590 characterize these wetter environments. It is also possible that Late Glacial and Holocene

591 glacial advances may have been more extensive than early glaciations and hence may

592 have destroyed any landform or sedimentary evidence of earlier glaciations in the

593 monsoon-influenced Himalayan regions. Due to the great relief in these settings, some

594 evidence of older glaciations is expected because of the large altitudinal separation of

595 landforms. On the other hand, the high relief yields more gravitational potential, which

596 would drive quicker reworking of landforms through various surface processes. 
598 Owen et al. $(2005,2006 a, 2008,2010,2012)$ and Seong et al. (2009) noted, that in

599 regions where there is evidence for very old glaciation there is a progressive change in

600 style of glaciation with a significant reduction in glacial extent over successive glacial

601 cycles. Owen $(2005,2006 a, 2008,2012)$ and Seong et al. (2009) hypothesized that this

602 could reflect a change in regional climatic forcing that might be the result of the

603 progressive surface uplift of adjacent mountain ranges that restricted moist input and

604 hence precipitation in their regions. They cautioned that drawing links between mountain

605 uplift and changes in regional climate is very tentative because it is not possible to define

606 the timing and magnitude of surface uplift for most mountain ranges. However, since this

607 pattern of glaciation occurs in disparate regions across the Transhimalaya and Tibet,

608 Owen et al. $(2005,2006 a, 2008,2010,2012)$ and Seong et al. (2009) argued that it might

609 reflect regional climate change rather than localized tectonics. In contrast, Dortch et al.

610 (2013) argue that most major glacial events are driven by monsoonal precipitation and

611 that change in regional climate is not likely responsible for decreased glacial extent

612 during the late Quaternary. An alternative mechanism is the adjustment of topographic

613 hypsometry to glacial erosion and the lowering of accumulation area driving the

614 reduction of glacial extent during late Quaternary cycles (e.g. Kaplan et al. 2009;

615 Pedersen and Egholm, 2013). The reason for this apparent changing pattern of glaciation

616 through time, however, has yet to be resolved.

617

618 6. The Last Glacial

619 There is abundant evidence in the Himalayan-Tibetan orogen for multiple glacial 
620 advances throughout the last glacial cycle. In some regions up to five distinct glacial

621 advances have been recognized, for example, in the Khumbu Himal (Finkel et al. 2003),

622 Muztag Ata-Kongus Shan (Seong et al. 2009a), and Xainza Range (Chevalier et al.,

623 2011). Care must be taken, however, when interpreting and trying to correlate glacial

624 successions because the preservation of the glacial geologic record may well be biased by

625 likely preservation potential (Gibbons et al., 1984).

626

627 Given the large number of ${ }^{10} \mathrm{Be}$ ages that have been generated in recent years, Owen et al.

628 (2008a) and Chevalier et al. (2011) examined the timing of glaciation by generating

629 probability distribution frequency plots for the ${ }^{10} \mathrm{Be}$ ages for selected time slices and

630 regions. Figure 17 builds on the analysis of Owen et al. (2008) by increasing their data set

631 from 777 to $>1700{ }^{10}$ Be ages. The new plots in Figure 17 use only moraine boulder ages.

632 As in Owen et al. (2008), we recognize that pooling all the ages runs the risk of including

633 ages that may be too old or too young to represent the true age of a glacial advance

634 because of the geological problems highlighted above. Given the great number of ages,

635 however, clear patterns emerge. As in the study by Owen et al. (2008a), the probability

636 plots shown in Figure 17 demonstrate a decrease in sample frequency with increasing

637 age. This is essentially a function of preservation, with younger landforms being better

638 preserved, more common and less difficult to date. Multiple peaks are apparent for most

639 of the probability plots during MIS 3 and the Late Glacial, and several peaks occur within

640 the Holocene. The new plots support the view of Owen et al. (2008a) that there is not a

641 dominant peak for the global LGM centered on $21 \mathrm{ka}$ but, instead, a dominant peak

642 occurs in the Late Glacial and is centered around 12-14 ka. In addition, the multiple 
643 peaks during the Holocene suggest that Himalayan-Tibetan glaciers may be sensitive to

644 climate oscillations, reflecting times of Holocene rapid climate change emphasized by

645 Mayewski et al. (2004).

646

647 The probability distribution frequency plots presented in Figure 17, however, may be

648 spurious since they combine data from climatically different regions where glaciers my

649 be responding differently to different climate forcing. To test for regional patterns, as in

650 Owen et al. (2008a), the ${ }^{10} \mathrm{Be}$ data have been sorted into four climatic-topographic

651 regions (Fig. 18): 1) Pamir and Tien Shan dominated by the mid-latitude westerlies; 2)

652 semi-arid Transhimalaya and western Tibet dominated by the mid-latitude westerlies); 3)

653 monsoon-influenced Himalaya including northern Pakistan, India and Nepal; 4)

654 monsoon-influenced Tibet, including southern central, central, SE and NE Tibet. Three

655 time slices are considered: 1) all ${ }^{10} \mathrm{Be}$ boulder ages back to $200 \mathrm{ka}$; 2) all ${ }^{10} \mathrm{Be}$ boulder

656 ages younger than 74 (MIS 5a); and 3) all ${ }^{10} \mathrm{Be}$ boulder ages younger than $15 \mathrm{ka}$ (to

657 include Late Glacial and Holocene ages). The study areas are listed in Table 3 and

658 Appendix 1.

659

660 The caveats in Figure 17 apply to the plots in Figure 18 when interpreting the data.

661 Clearly the probability plots still reflect bias in occurrence and sampling of younger

662 moraines and the distributions are broadly similar. It is notable that there is no peak

663 centered on 30-50 ka (MIS 3) for the Pamir and Tien Shan data, but rather there is a

664 peak at 60-75 ka (MIS 4); however, there is no peak at this time for the other three

665 regions (Fig. 18A). However, due to significantly fewer samples collected from 
666 landforms $>30 \mathrm{ka}$ in age, erosional processes could easily diminish any $>30$ ka peak into 667 the background so that the sampled regions of Pamir and Tien Shan may only reflect a 668 particular peak due to very dry conditions promoting preservation. The Pamir and Tien

669 Shan data have apparent bimodal peaks between the Late Glacial through to the global 670 LGM, whereas no other data set has a peak at the global LGM (Fig. 18B). As pointed out

671 by Owen et al. (2008a), this suggests that glaciation in the Pamir and Tien Shan has 672 responded differently compared to the other three regions. In contrast, Dortch et al.

673 (2013) shows a strong regional glacial signal at 20 \pm 2 ka in the Pamir and Western

674 Transhimalaya by analyzing individual datasets, highlighting the weakness of combining 675 datasets without first eliminating outliers. It is likely that glaciation in the Pamir and Tien 676 Shan is forced by northern hemisphere climate change and is broadly synchronous with 677 oscillations in the northern hemisphere ice sheets. In contrast, as suggested by numerous 678 researchers, in other areas of the Himalayan-Tibetan orogen, glaciers respond to changes 679 in the south Asian monsoon. In particular, the peak centered around MIS 3 supports the 680 view that glaciers advanced during a time of increased insolation, which helped drive the 681 monsoon influence farther into the orogen resulting in increased precipitation and 682 cloudiness, further resulting in positive glacier mass balances (e.g. Finkel et al., 2003;

683 Owen et al., 2003a, 2005, 2006b, 2009; Rupper et al., 2008). Moreover, the ages and 684 glacial geologic evidence shows that, in many regions of the Himalayan-Tibetan orogen, 685 glaciers advanced to their largest extents earlier in the last glacial cycle than the northern 686 hemisphere ice sheets, thus supporting the views of Gillespie and Molnar (1995) and 687 Thackray et al. (2008). 
689 The probability distribution frequency plots also show a significant Late Glacial advance

690 (Fig. 18C). The peaks are broad and it is not possible to assign the advance to a particular

691 stadial such as the Younger Dryas.

692

693 Figure 19 examines regional variability in more detail. The picture that emerges is

694 complex, it being evident that many of the glacial advances span long durations, in some

695 cases many tens of thousands of years. This largely reflects the uncertainty in the

696 chronological control. As a consequence, it is clear that a lot of age data are dispersed

697 within probability distribution frequency plots but, nevertheless, the plots are useful for

698 examining possible broad trends. The bars representing glacial advances shown in Figure

69919 are color coded to help recognize correlations. Particularly notable is the lack of

700 glacial advances prior to the Late Glacial in many of the monsoon-influenced regions of

701 the Himalaya and Tibet. Possible reasons for this were discussed above. Notable glacial

702 advances occurred during the Late Glacial, early Holocene, mid-Holocene, Neoglacial

703 and during the last millennia in nearly all areas. The data suggest broad patterns with

704 glaciers responding at Milankovitch and sub-Milankovitch frequencies; it is likely that,

705 for most regions both the monsoon and mid-latitude westleries force glaciation, albeit to

706 different extents. This makes it difficult to correlate glacial stages across the orogen. 707

708 When considered in more detail, the patterns are even more complex. Figure 20, for

709 example, highlights the main study areas at the western end of the Himalayan-Tibetan

710 orogen. The timing of the local last glacial maximum is indicated on the left of the figure,

711 with approximate maximum extents of glaciation. ELA data are not presented because of 
712 the complexity of determining them for each region (see Benn and Lehmkuhl, 2000,

713 Benn et al., 2005 and Owen and Benn, 2005 for more discussion). The pattern that

714 emerges is very complex with the local last glacial maximum occurring at very different

715 times across the western end of the orogen. Figure 20 also compares these data with the

716 climate modeling presented in Bishop et al. (2010) that covers the same aerial extent. The

717 variation in snowfall across the region and between time slices is striking. Although the

718 modeling focuses on the global LGM and the Holocene, it illustrates the complex and

719 differing patterns across the region at different times. It is therefore not surprising that the

720 style and timing of glaciation across the orogen is complex.

721

722 Despite this complexity, Dortch et al. (2013) examined the glacial successions and ${ }^{10} \mathrm{Be}$

723 ages across the semi-arid regions at the western end of the Himalayan-Tibetan orogen to

724 develop a regional framework for glaciation across these dryland regions. Using Gaussian

725 separation, Dortch et al. (2013) recognized nineteen regional glacial stages that they

726 named the semi-arid western Himalayan-Tibetan stages (SWHTS). These are illustrated

727 in Figure 21. The data suggest that regional glacial stages older than 21 ka are broadly

728 correlated with a greater monsoonal influence. SWHTS that are 21 ka or younger have

729 smaller uncertainties and broadly correlate with global ice volume as defined by marine

730 oxygen isotope stages and northern hemisphere climatic events (Oldest Dryas, Older

731 Dryas, Younger Dryas, Roman Humid Period, and Little Ice Age). The pattern of

732 glaciation that emerges shows no significant spatial clustering within the study area even

733 though several correlative advances throughout the region were identified. The lack of

734 spatial grouping and correlation between glacial chronologies and climatic records led 
735 Dortch et al. (2013) to speculate that the arid regions respond to small fluctuations in

736 precipitation brought via the mid-latitude westerlies, sediments being subsequently wiped

737 out by larger, less frequent monsoon driven advances. This view is in agreement with

738 Seong et al. (2009) regarding westerly control of post-LGM advances outlined below. 739

740 Using the methods of Dortch et al. (2013), Murari et al. (2013), together with new ${ }^{10} \mathrm{Be}-$

741 ages to define the timing of glaciation in SW Garhwal, examined the glacial chronologies

742 throughout the monsoon-influenced regions of the Himalaya. They recognized 29

743 regional glacial stages, which they called monsoon-influenced Himalayan-Tibet stages

744 (MOHITS). Murari et al. (2013) suggest that there are strong correlations with both

745 periods of strong monsoons and northern hemisphere events throughout the entire

746 chronologic range. They identify 16 stages linked to the monsoon and 11 stages linked to

747 the mid-latitude westerlies (two unassigned) with a complex pattern of glaciation

748 influenced by two climatic systems since the mid/late Quaternary. The larger number of

749 regional glacial stages compared to the semi-arid regions suggests more frequent moraine

750 deposition during the last glacial cycle and the Holocene. However, this may be an

751 artifact of the larger number of dated glacial sediments and landforms in the monsoon

752 influenced regions.

753

754 Comparison between the semi-arid and monsoon influenced regions are shown in Figure

75521 and visually compared with the SWHITS, and statically compared using the student t-

756 test in Table 4. We recognize that much care must be taken when making such

757 correlations within between regions as large as the Himalayan-Tibetan orogen because 
758 some detailed complexity may be lost with grouping of data statistically. However, the

759 correlations provide a framework for future studies. Moreover, it is very striking the large

760 dataset is now developing to define the timing of glacier oscillations throughout the

761 region over the last half million years, and the high frequency of those oscillations.

762

763 7. Holocene Glaciation

764 Zhou et al. (1991), Yi et al. (2008) and Owen (2011) provide useful summaries of the

765 nature of Holocene glacier fluctuations in the Himalaya and Tibet. In particular, Owen

766 (2011) drew attention to the paucity of comprehensive studies of Holocene glaciation in

767 the region, but emphasized the potential to derive a high-resolution (sub-millennial scale)

768 record of glaciation for paleoclimatic change using the Holocene glacial record. This is

769 because the Holocene glacial record is better preserved than older moraine successions

770 and numerical dating can be more readily and successfully applied to younger moraines.

771 The Yi et al. (2008) review included a compilation of 53 radiocarbon ages for Holocene

772 glacial advances in Tibet, which they argued that glaciers advanced at 9.4-8.8 ka, 3.5-1.4

$773 \mathrm{ka}$, and 1.0-0.13 ka, suggesting that glaciation in Tibet is synchronous with cooling

774 periods identified in the $\delta^{18} \mathrm{O}$ record of ice core. Zhou et al. (1991) showed that Holocene

775 continental glaciers in northwest China advanced at $\sim 9.3 \mathrm{ka}, 6.4 \mathrm{ka}, 4.5 \mathrm{ka}$, and $0.5 \mathrm{ka}(\sim$

$7768300,5700,4000$ and $400{ }^{14} \mathrm{C}$ years BP), while maritime-influenced glaciers in

777 southeastern Tibet advanced at $3.1 \mathrm{ka}, 1.9 \mathrm{ka}, 0.9 \mathrm{ka}$, and $0.3 \mathrm{ka}(\sim 3000,2000,1000$, and

$778200{ }^{14} \mathrm{C}$ years BP), arguing for a 2500-year climate cycle at $~ 9.3 \mathrm{ka}, 6.4 \mathrm{ka}, 3.2 \mathrm{ka}$ and

$7790.3 \mathrm{ka}\left(8300,5700,3000\right.$ and $200{ }^{14} \mathrm{C}$ years BP $)$, and a 1000-year climate cycle at 3.2

$780 \mathrm{ka}, 1.9 \mathrm{ka}, 0.9 \mathrm{ka}$, and $0.3 \mathrm{ka}\left(\sim 3000,2000,1000\right.$, and $200{ }^{14} \mathrm{C}$ years BP). 
782 Röthlisberger and Geyh (1985a,b) and Seong et al. (2009a) are arguably the two most

783 significant quantitative studies of Holocene moraines in the Himalayan-Tibetan orogen

784 that present primary data. Both studies also included an examination of global LGM and

785 Late Glacial moraines. Röthlisberger and Geyh (1985a,b), presented 68 radiocarbon ages

786 from around 16 different glaciers in Pakistan, India and Nepal to show that glaciers

787 advanced at $\sim 8.3 \mathrm{ka}, 5.4-5.1 \mathrm{ka}, 4.2-3.3 \mathrm{ka}$, and 2.7-2.2 ka (7400, 4900-4600, 3700-

$7883100,2700-2100{ }^{14} \mathrm{C}$ years BP) with relatively small extensions at 2.6-2.4 ka (2500-

$7892300{ }^{14} \mathrm{C}$ years BP), 1.7-1.4 ka, 1.3-0.9 ka, 0.8-0.55 ka and 0.5-0.1 ka (1700-1500,

$790 \quad 1200-950,800,550$ and $400-100{ }^{14}$ C years BP; Fig. 9).

791

792 The study of Seong et al. (2009a) utilized ${ }^{10}$ Be TCN dating of moraines around Mustah

793 Ata and Kongur Shan in the Chinese Pamir to show that glaciers advanced at $\sim 11.2 \mathrm{ka}$,

$794 \quad 10.2 \mathrm{ka}, 8.4 \mathrm{ka}, 6.7 \mathrm{ka}, 4.2 \mathrm{ka}, 3.3 \mathrm{ka}, 1.4 \mathrm{ka}$, and at a few hundred years before the

795 present (Fig. 22). They argued that, since the global LGM, glaciers in western Tibet

796 likely responded to Northern Hemisphere climate oscillations, with minor influences

797 from the south Asian monsoon, responding on millennial timescales to Holocene rapid

798 climate changes that were highlighted by Bond et al. $(1997,2001)$ and Mayewski et al.

799 (2004) (Fig. 22).

800

801 The probability distribution plots in Figure 18C, and introduced in the previous section,

802 show significant early Holocene peaks. The early Holocene advance likely reflects

803 similar monsoonal forcing to the MIS 3 advance, since this was a time of increased 
804 insolation and enhanced monsoonal influence. Climate modeling supports the view that

805 increased precipitation and snowfall throughout much of the Himalayan-Tibetan region

806 took place during the early Holocene (Bush, 2004, Rupper et al., 2008; Li and Harrison,

807 2008; Bishop et al., 2010). Rupper et al. (2008) argued that an increase in cloudiness

808 reduces incoming shortwave radiation that results in greater cooling at the surface of the

809 glacier and accounts for more of the ELA lowering than an increase in monsoon

810 precipitation. Multiple peaks are evident for the mid- and late Holocene, representing

811 millennial-scale glacier oscillations. These glacial advances may reflect periods of rapid

812 climate change influenced by teleconnections to Northern Hemisphere climate systems as

813 suggested by Seong et al. (2009a) and Owen (2009).

814

815 As Owen (2009) underscored, these studies support the view that Himalayan and Tibetan

816 glaciers oscillated at a comparable frequency to that recognized in ice cores from the

817 Greenland Ice Sheet and in deep-sea sediment cores from the North Atlantic, where a

818 quasi-periodicity of $\sim 1470$ years is apparent throughout the Late Glacial and Holocene

819 (Bond et al., 1997, 2001). Seong et al. (2009a) and Owen (2009) pointed out that the

820 duration of quasi-periodicity of glacial oscillations throughout the Holocene is similar to

821 climatic oscillations recognized in the North Atlantic by Mayewski et al. (2004), and

822 suggested that regional climate change in Tibet may well be forced by teleconnections

823 via mid-latitude westerlies and Atlantic climate change. Moreover, Owen (2009)

824 suggested that it is likely that as many as eight significant glacial advances would be

825 expected to have occurred throughout the Holocene in Himalayan-Tibetan regions. He

826 also stressed that rapid climate change and accompanied glacial oscillations is also 
827 supported by the ice core data from Tibetan ice sheets, which show short (millennial-

828 centennial) abrupt oscillations in climate throughout the Late Quaternary (Thompson et

829 al., 1989, 1997; Thompson, 2000; Yao et al., 1996, 1997). In addition, Dortch et al.

830 (2013) recognized late-Pleistocene and early Holocene glacial advances that correlate

831 with Heinrich events. They documented three regional glacial advances during the latter

832 part of the Holocene in the semi-arid western end of the Himalayan-Tibetan orogen at

$8333.7 \pm 0.6 \mathrm{ka}$ (SWHT 1C), 1.6 $\pm 0.3 \mathrm{ka}$ (SWHTS 1B) and 0.4 $\pm 0.1 \mathrm{ka}$ (SWHTS 1A) that they

834 argue broadly correlate with Northern Hemisphere climatic events (Fig. 21).

835

836 Unlike many other mountain regions throughout the world, the most extensive glacial

837 advance during the Holocene in the Himalayan-Tibetan orogen occurred during the early

838 Holocene (cf. Grove, 2004; Clapperton, 1993; Porter, 2000). This advance is represented

839 by impressive suites of sharp-crested moraines which have been dated by numerous

840 researchers using radiocarbon, OSL and TCN methods to between $\sim 11.5$ and $8.0 \mathrm{ka}$

841 (Shiraiwa, 1993; Sharma and Owen, 1996; Phillips et al., 2000; Richards et al., 2000a;

842 Owen et al., 2001, 2002b, 2003a,c, 2005, 2006a,b; Finkel et al., 2003; Zech et al., 2003,

843 2005; Barnard et al., 2004a,b, 2006a,b; Spencer and Owen, 2004; Abramowski et al.,

844 2006; Jiao and Shen, 2006; Seong et al., 2007, 2009a; Meyer et al., 2009; Chevalier et al.,

845 2011). The extent of glacial advances and ELA depressions during the early Holocene

846 varies considerably between regions; for example, glaciers only advanced a few

847 kilometers in the Muztag Ata-Konga Shan and Hunza regions with an ELA depression of

$848<200 \mathrm{~m}$ (Benn and Owen, 2005; Seong et al., 2009c) as compared to the Central

849 Karakoram where glaciers advanced several tens of kilometers with an ELA depression 
850 of $>500 \mathrm{~m}$ (Seong et al., 2009b). The disparity of ELA depression may be due to relief

851 control of precipitation as outlined by Bookhagen and Burbank (2006), with the high-

852 relief Karakoram receiving more precipitation due to orographic effects.

853

854 Figure 19 highlights this early Holocene regional signal, but the resolution of the dating

855 in most of the studies, which generally utilize TCN methods, is too coarse to determine

856 whether this apparent correlation is synchronous on a millennial scale. Moreover, most of

857 the dating does not allow us to distinguish whether the early Holocene advance was

858 synchronous with the early Holocene isolation maximum, and hence is a monsoon signal,

859 or the 8.5 ka cold event, or both. Reducing the dating uncertainty on early Holocene

860 moraines is clearly an area that needs attention in order to advanve understanding of the

861 nature of early Holocene glaciation and climate change.

862

863 Owen (2011) pointed out that mid-Holocene ( 8.0-3.0 ka, Hypsithermal) moraines have

864 been dated in several regions of the Himalaya and Tibet. These moraines are generally

865 well preserved and often comprise latero-frontal moraine complexes. As Owen (2011)

866 points out, the Hypsithermal has yet to be adequately defined by glacial geologic proxies

867 for the Himalaya and Tibet and the use of the term in this region should therefore be used

868 very conservatively. Moreover, it may be diachronous in monsoonal Asia (An et al.,

869 2000). Significant glacial advances (a few kilometers beyond present ice margins) have

870 been recognized, however, for selected glaciers in Tibet (Zhou et al., 1991), in the

871 Khumbu Himal (Finkel et al., 2003), the Diancang Mountain in the Hengduan Range

872 (Yang et al., 2006), Qilian Shan (Wu, 1984a), and in Muztag Ata and Konga Shan (Seong 
873 et al., 2009a). Climatic simulations support the view that increased monsoon precipitation

874 and cloudiness, and summer cooling over the Himalaya and Tibet would have helped

875 force glaciation during the mid- Holocene, albeit not as great as during the early

876 Holocene (Bush, 2002, 2004; Li and Harrison, 2008; Rupper et al., 2008).

877

878 Many studies have attributed sharp-crested, well-preserved moraines within a kilometer

879 of the present glacier margin to the Neoglaciation, which is younger than 3-2.7 ka (e.g.

880 Benedict, 1976; Fushimi, 1978; Derbyshire et al., 1984; Wu, 1984a; Zheng, 1997;

881 Richards et al., 2000a; Finkel et al., 2003; Zheng, 1997; Owen et al., 2005; Jiao and Shen,

882 2006; Seong et al., 2009a, Meyer et al., 2009). Yet many of these studies do not have

883 adequate numerical dating to show moraines are, indeed, Neoglacial and the extensive

884 early Holocene advance can be easily misinterpreted as Neoglacial. Moreover, as Owen

885 (2011) points out, the onset of the Neoglaciation in the Himalayan-Tibetan orogen may

886 be asynchronous.

887

$888 \mathrm{Pu}$ (1991), for example, defines four Neoglacial advances (Neoglaciation I-IV) in

889 western China, including Tibet, which date to 9.2-7.8 ka, 6.7-5.6 ka, 3.6-2.4 ka, and

$890 \quad 0.5-0.03 \mathrm{ka}\left(\sim 7000-8200,4900-5800,2400-3320\right.$ and $450-30{ }^{14} \mathrm{C}$ years BP). Clearly,

891 by the definition of Neoglaciation (see Denton and Karlén, 1973, Porter, 2000; Porter and

892 Denton, 1967), the first two of these advances did not occur in the Neoglacial. Therefore,

893 as Owen (2011) emphasizes, confused nomenclature as well as the challenges of dating

894 moraines adds to the complexity of understanding Holocene glaciation in the Himalayan-

895 Tibetan orogen. Yang et al. (2008) showed three main periods of glacial advance at 
896 around 1.8-1.4 ka, 1.2-1.15 ka, and 0.6-0.08 ka in the Hengduan Mountains, the central

897 and eastern parts of the Himalaya and the eastern Nyainquentanghlha Range of SE Tibet.

898 This complex array of ages suggests that glaciers likely would have been responding to

899 climate change throughout the Himalayan-Tibetan orogen in a very complicated fashion.

900

901 Glacial advances during the Little Ice Age (LIA) in the Himalayan-Tibetan orogen are

902 not well defined. There are few definitive studies providing ages on moraines that can be

903 attributed to the LIA. The most notable ones include studies in the Khumbu Himal that

904 have been dated by both radiocarbon and TCN methods (Benedict, 1976; Fushimi, 1978;

905 Finkel et al., 2003). Yi et al. (2008) collates all the published radiocarbon ages for LIA

906 moraines from Nyainqentanglha, Karakoram, Langtang, the western slopes of

907 Namjagbarwa Peak in the eastern Himalaya and Gonga in SE Tibet to show that the LIA

908 in Tibet had three substages between 1.0 to $0.13 \mathrm{ka}$. Dortch et al. (2013) showed that a

909 significant regional glacial stage is recognized across the semi-arid western end of the

910 Himalayan-Tibetan orogen at $0.4 \pm 0.1 \mathrm{ka}$ (Fig. 21).

911

\section{8. Historical and predicted future changes}

913 In most areas of the Himalayan-Tibetan orogen, glaciers began to retreat after the LIA at

914 the beginning of the $20^{\text {th }}$ Century and have continued to retreat since (Mayewski and

915 Jeschke, 1979; Mayewski et al., 1980; Ono, 1984, 1985, 1986; Ono et al., 1997; Shi and

916 Lui, 2000; Su and Shi, 2002; Fujita et al., 1997; Ren et al., 2004; Bolch et al., 2008).

917 Cogley (2011) provides a comprehensive glacier inventory for the Himalaya and

918 Karakoram containing 20,812 glaciers covering an area of 43,178 $\mathrm{km}^{2}$. Undertaking a 
919 glacier-by-glacier analysis, Cogley (2011) suggests that up to about one-fifth of the

920 glaciers present in 1985 may have disappeared. Furthermore, Cogley (2011) argues that,

921 if mass loss were to remain constant at the average rate for 1975-2008, from 3000 to

92213,000 more glaciers might disappear by 2035. Moreover, he suggests that if mass loss

923 were to continue to accelerate as inferred for 1985-2008, only a few thousand to a few

924 hundred glaciers might remain in 2035. Cogley (2011) acknowledges that these

925 projections are uncertain and neglect some possibly important mitigating controls, but

926 they demonstrate the need for more complete analyses to help define the reduction and

927 assess its potential effects.

928

929 Su and Shi (2002) argue that, since the height of the LIA during 17th century, the mean 930 temperature of temperate monsoonal glaciers in China has increased by $0.8^{\circ} \mathrm{C}$ and their

931 area has decreased by $\sim 3900 \mathrm{~km}^{2}$, an amount equivalent to $30 \%$ of the area of modern

932 glaciers. Moreover, Su and Shi (2002) argue that if temperature rises by $2.1^{\circ} \mathrm{C}$ as may be

933 likely by the year 2100 , then temperate monsoonal glaciers in China are likely to

934 decrease by $75 \%$, an $~ 9900 \mathrm{~km}^{2}$ loss of area. Furthermore, if precipitation decreases as

935 well, then the retreat of the glaciers will be even faster. However, Su and Shi (2002)

936 argue that the area reduction percentage of the glaciers is unlikely to exceed $80 \%$. Some

937 regions have experienced accelerated glacier retreat in recent decades often resulting in

938 the formation of impressive supraglacial lakes (Benn et al., 2001).

939

940 The rate of retreat over the past 30 years in some regions, however, has been less than

941 during the earlier part of the $20^{\text {th }}$ century (Copland et al., 2011). In some regions, certain 
942 glaciers have begun to stabilize and/or advance during the past few years. Some glaciers

943 have even been remarkably stable, such as Baltoro Glacier in northern Pakistan that has

944 varied by no more than $\pm 200 \mathrm{~m}$ since the 1850 s (Mayer et al., 2006). In some regions,

945 such as the Karakoram, individual glaciers have advanced and retreated during the last

946 century, sometimes surging (Hewitt, 1969, 2005; Barrand and Murray, 2006; Copland et

947 al., 2011).

948

949 Predicting increasing mean annual temperatures due to human activity will cause glaciers

950 to melt, retreat and eventually disappear is challenging. Other factors including, for

951 example, increased deposition of black carbon on glaciers, will enhance melting.

952 However, the large altitudinal range, and the complex topographic setting, and

953 microclimatic variations make it difficult to quantify future temperature change and its

954 net effect on glacier melting. In monsoon-influenced regions, predicted increased

955 snowfall and increased cloudiness may lead to positive glacier mass balances.

956 Consequently, some glaciers may thicken and advance. These glaciers may eventually

957 retreat as the increase of mean annual temperature out-competes the increased glacier

958 growth due to enhanced snowfall and cloudiness; this change may be rapid if summer

959 snows become summer rain.

960

961 9. Future progress

962 Understanding of the nature, timing, and extent of Late Quaternary glaciation in the

963 Himalayan-Tibetan orogen has advanced rapidly and significantly in the past decade or

964 so, specifically aided by improvements in remote sensing and dating methods, but the 
965 vastness and the political and logistical inaccessibility of much of the region still present

966 significant challenges. Numerical dating studies suggest that, on millennial timescales,

967 glaciation is broadly synchronous throughout the orogen, but the exact timing and extent

968 of glaciation varies considerably within and between different mountain ranges within

969 Highland Asia. The complex patterns of glaciation that are emerging imply that

970 glaciation throughout the Himalayan-Tibetan orogen reflects temporal and spatial

971 variability of forcing by the different climatic systems that dominate the region. As Owen

$972(2009 ; 2013)$ indicated the style and timing of glaciation appears to be strongly controlled

973 by climatic gradients, but topography may also have an important control. Correlation

974 between regions is hindered because of large uncertainties related to the dating methods,

975 mainly TCN and OSL methods. Reducing these uncertainties and developing stronger

976 correlations can be achieved by improving the dating methods, and by using two or more

977 dating techniques (for example Owen et al. 2009, 2001). A productive area of research

978 might include numerical modeling of landform degradation to help explain the

979 distribution of TCN ages on landforms since a post-depositional modification of

980 landforms results can result in significant underestimates of TCN ages. In spite of these

981 challenges, geologic error outweighs uncertainties in current dating methodologies. In

982 addition, the lack of a standard way in which to interpret TCN results can lead to

983 erroneous correlations or the missing of valid correlations. Thorough numerical analysis

984 of dating results using methods such as those described by Dortch et al. (2013) is

985 beginning to allow regional glacial stages to be recognized, forming a stronger

986 foundation for the study of Quaternary glaciation in the Himalayan-Tibetan realm. 
988 Owen et al. $(2005,2009,2010,2012)$ and Owen (2013) pointed out that the extent of

989 glaciation has become increasingly restricted throughout the Late Quaternary in the more

990 arid regions of Highland Asia, which has helped preserve very old (pre-last glacial cycle)

991 glacial landforms. In regions very strongly influenced by the monsoon, the preservation

992 potential of pre-Late Glacial moraines is poor. Owen et al. (2005) suggest that this may

993 be because Late Glacial and Holocene glacial advances were the most extensive,

994 destroying the geomorphic or sedimentary evidence of earlier glaciations, together with

995 the intense fluvial and mass movement denudation that is characteristic of the wetter

996 regions.

997

998 Mid-Holocene Neoglaciation, LIA, and historical glacial records testify to a progressive

999 retreat of glaciers during the twentieth century and warn of a continued retreat during the

1000 coming century, but the pattern is complex and the glaciers may be asynchronous during

1001 these climatostratigraphic times, issues that need to be considered in more detail.

1002 Fortunately, because of the better preservation of the Holocene glacial record and

1003 because numerical dating can more readily be applied to Holocene landforms and

1004 sediment, we should target interesting times of climatic instability: the early Holocene,

1005 Neoglaciation, and specifically, the LIA. The use of other geologic proxies such as lake,

1006 aeolian and ice core records should be further utilized. Climatic and glacial modeling also

1007 has great potential to provide valuable information regarding the patterns and possible

1008 complexity of change.

1009

1010 In sum, the Himalayan-Tibetan orogen provides an exciting natural laboratory for the 
1011 examination of the links between climatic and glacial systems which, in turn has

1012 important implications for the geomorphology and hydrology of the high mountains and

1013 their forelands in Asia. The numerous studies that have been undertaken in this region

1014 have established a broad framework, which can be also be used to develop and identify

1015 intriguing, more specific questions about climatic-glacial-erosional linkages.

1016

1017 Acknowledgements

1018 Sincere thanks to Neil Glasser and Tim Horscroff for encouraging us to write this paper

1019 and being patient with our submission time. Many thanks to three anonymous referees

1020 who provided very constructive and useful comments to help us improve our paper and to

1021 Craig Dietsch for his advice of our manuscript. This paper was presented in an early form

1022 by LAO as an invited lecture at the American Geophysical Union Annual Meeting in San

1023 Francisco in December 2012.

1024

1025 References

1026 Abramowski, U., 2004. The use of ${ }^{10}$ Be surface exposure dating of erratic boulders in the reconstruction of

1027 the late Pleistocene glaciation history of mountainous regions, with examples from Nepal and Central Asia.

1028 Unpublished PhD., Universität Bayreuth, Germany, 167p.

1029

1030 Abramowski, U., Bergau, A., Seebach, D., Zech, R., Glaser, B., Sosin, P., Kubik, P.W., Zech, W., 1031 2006. Pleistocene glaciations of Central Asia: results from ${ }^{10} \mathrm{Be}$ surface exposure ages of erratic

1032 boulders from the Pamir (Tajikistan) and the Alay-Turkestan range (Kyrgyzstan). Quaternary

1033 Science Reviews 25, 1080-1096.

1034 
1035 Ali, S.N., Biswas, R.H., Shukla, A.D., Juyal, N., 2013. Chronology and climatic implications of Late

1036 Quaternary glaciations in the Goriganga valley, central Himalaya, India. Quaternary Science Reviews

$1037 \quad 73,59-76$.

1038

1039 An, Z., Porter, S.C., Kutzbach, J.E., Wu, X., Wang, S., Liu, X., Li, X., Zhou, W., 2000.

1040 Asynchronous Holocene optimum of the East Asian monsoon. Quaternary Science Reviews, 19, $1041743-762$.

1042

1043 Aoki, T., Imamura, M., 1999. Reconstructing the glacial chronology based on the 10Be exposure

1044 age in the Khumbu Glacier, Eastern Nepal Himalaya. Proceedings of the Korea-Japan/Japan-

1045 Korea Geomorphological Conference, 134-135.

1046

1047 Applegate, P.J., Urban, N.M., Laabs, B.J.C., Keller, K., Alley, R.B., 2010. Modeling the

1048 statistical distributions of cosmogenic exposure dates from moraines. Geoscientific Model

1049 Development 3, 293-307.

1050

1051 Bagla, P., 2009. No sign yet of Himalayan meltdown, Indian report finds. Science 326, 924-925.

1052

1053 Balco, G., Stone, J.O., Lifton, N.A., Dunai T.J., 2008. A complete and easily accessible means of

1054 calculating surface exposure ages or erosion rates from $10 \mathrm{Be}$ and $26 \mathrm{Al}$ measurements.

1055 Quaternary Geochronology 8, 174-195.

1056

1057 Balco, G., Briner, J., Finkel, R.C., Rayburn, J.A., Ridge, J.C., Schaefer, J.M., 2009, Regional

1058 beryllium-10 production rate calibration for northeastern North America. Quaternary

1059 Geochronology 4,. 93-107.

1060 
1061 Barnard, P.L., Owen, L.A., Finkel, R.C., 2004a. Style and timing of glacial and paraglacial 1062 sedimentation in a monsoonal influenced high Himalayan environment, the upper Bhagirathi

1063 Valley, Garhwal Himalaya. Sedimentary Geology 165, 199-221.

1064

1065 Barnard, P.L., Owen, L.A., Finkel, R.C., Asahi, K., 2006. Landscape response to deglaciation in a

1066 high relief, monsoon-influenced alpine environment, Langtang Himal, Nepal. Quaternary Science

1067 Reviews 25, 2162-2176.

1068

1069 Barnard, P.L., Owen, L.A., Sharma, M.C., Finkel, R.C., 2004b. Late Quaternary (Holocene)

1070 landscape evolution of a monsoon-influenced high Himalayan valley, Gori Ganga, Nanda Devi,

1071 NE Garhwal. Geomorphology 61, 91-110.

1072

1073 Barrand, N. E., Murray, T., 2006. Multivariate controls on the incidence of glacier surging in the

1074 Karakoram Himalaya. Arctic, Antarctic, and Alpine Research 38, 489-498.

1075

1076 Bäumler R, Zech, W., Ni, A.A., Savoskul, O., 1999. Soil geographical and pedogeochemical

1077 studies on Pleistocene and Holocen glaciation in the Northwestern Tien Shan (Uzbekistan)

1078 Zeitschrift fur Gletscherkunde und Glazialgeologie 35, 147-173.

1079

1080 Benedict, J.B., 1976. Khumbu glacier series, Nepal. In: Buckley, J., Isotopes’ radiocarbon

1081 measurements XI Radiocarbon 18, 177-178.

1082

1083 Benn DI, Lehmkuhl F., 2000. Mass balance and equilibrium-line altitudes of glaciers in high

1084 mountain environments. Quaternary International 65/66, 15-29.

1085 
1086 Benn, D.I., Owen, L.A., Osmaston, H.A., Seltzer G.O., Porter C.S., Mark B., 2005.

1087 Reconstruction of equilibrium-line altitudes for tropical and sub-tropical glaciers. Quaternary

1088 International 138/139, 8-21.

1089

1090 Benn, D.I., Owen L.A., 1998. The role of the Indian summer monsoon and the mid-latitude

1091 westerlies in Himalayan glaciation: review and speculative discussion. Journal of the Geological

1092 Society $155,353-363$.

1093

1094 Benn, D.I., Owen, L.A., 2002. Himalayan glacial sedimentary environments: a framework for

1095 reconstructing and dating former glacial extents in high mountain regions. Quaternary

1096 International 97/98, 3-26.

1097

1098 Benn, D.I., Wiseman, S., Hands, K.A., 2001. Growth and drainage of supraglacial lakes on

1099 debris-mantled Ngozumpa Glacier, Khumbu Himal, Neapl. Journal of Glaciology 47, 626-638.

1100

1101 Bishop, M.P., Bush, A., Copland, L., Kamp, U., Owen, L.A., Seong, Y.B., Shroder, J.F., 2010.

1102 Climate Change and Mountain Topographic Evolution in the Central Karakoram, Pakistan.

1103 Annals of Geography 100, 1-22.

1104

1105 Böhner, J. 2006. General climatic controls and topoclimatic variations in Central and High Asia.

1106 Boreas 35, 279-295.

1107

1108 Bolch, T., Buchroithner, M. F., Pieczonka, T., Kunert, A., 2008. Planimetric and Volumetric

1109 Glacier Changes in the Khumbu Himalaya since 1962 Using Corona, Landsat TM and ASTER

1110 Data. Journal of Glaciology, 54, 592-600.

1111 
1112 Bond, G., Showers, W., Cheseby, M., Lotti, R., Almasi, P., deMenocal, P., Priore, P., Cullen, H.,

1113 Hajdas I., Bonani, G., 1997. A pervasive millennial-scale cycle in North Atlantic Holocene and

1114 glacial climates. Science 278, 1257-1266.

1115

1116 Bond, G., Kromer, B., Beer, J., Muscheler, R., Evans, M., Showers, W., Hoffmann, S., Lotti-

1117 Bond, R., Hajdas, I., Bonani, G., 2001. Persistent solar influence on North Atlantic climate during

1118 the Holocene. Science 294, 2130-2136.

1119

1120 Bookhagen, B. \& Burbank, D.W. 2006. Topography, relief, and TRMM-derived rainfall

1121 variations along the Himalaya. Geophysical Research Letters, 33, L08405.

1122

1123 Bookhagen, B., Thiede, R.C. \& Strecker, M.R. 2005. Late Quaternary intensified monsoon

1124 phases control landscape evolution in the northwest Himalaya. Geology, 33, 149-152.

1125

1126 Bookhagen, B. (in review): High resolution spatiotemporal distribution of rainfall

1127 seasonality and extreme events based on a 12-year TRMM time series, in review.

1128

1129 Briner, J.P., Young, N.E., Goehring, B.M., Schaefer,J.M., 2012. Constraining Holocene ${ }^{10}$ Be

1130 production rates in Greenland. Journal of Quaternary Science 27, 2-6.

1131

1132 Brown, E.T., Bendick, R., Bourles, D.L., Gaur, V., Molnar, P., Raisbeck, G.M., Yiou, F., 2002.

1133 Slip rates of the Karakoram fault, Ladakh, India, determined determined using cosmic ray

1134 exposure dating of debris flows and moraines. Journal of Geophysical Research 107, B9, 2192, 7 -

1135 1-7-8.

1136 
1137 Brozović, N., Burbank, D.W., Meigs, A.J., 1997. Climatic limits on landscape development in the 1138 northwestern Himalaya. Science 276. 571-574.

1139

1140 Burbank, D.W., Fort, M.B., 1985. Bedrock control on glacial limits: Examples from the Ladakh

1141 and Zanskar Ranges, north-western Himalaya, India. Journal of Glaciology 31, 143-149.

1142

1143 Burbank, D.W., Kang, J.C., 1991. Relative dating of Quaternary moraines, Rongbuk Valley,

1144 Mount Everest, Tibet: Implications for an Ice Sheet on the Tibetan Plateau. Quaternary Research

$1145 \quad 36,1-18$.

1146

1147 Bush, A.B.G., 2000. A positive climatic feedback mechanism for Himalayan glaciation.

1148 Quaternary International 65/66, 3-13.

1149

1150 Bush, A.B.G. 2002. A comparison of simulated monsoon circulations and snow accumulation in

1151 Asia during the mid-Holocene and at the Last Glacial Maximum. Global and Planetary Change

$115232,331-347$.

1153

1154 Bush, A.B.G., 2001. Pacific sea surface temperature forcing dominates orbital forcing of the

1155 Early Holocene monsoon. Quaternary Research 55, 25-32.

1156

1157 Bush, A.B.G., 2004. Modeling of late Quaternary climate over Asia; a synthesis. Boreas 33, 155 -

1158163.

1159

1160 Chevalier, M.-L., Ryerson, F.J., Tapponnier, P., Finkel, R.C., Van Der Woerd, J., Haibing, L.,

1161 Qing, L., 2005. Slip-rate measurements on the Karakoram Fault may imply secular variations in 1162 fault motion. Science 307, 411-414. 
1164 Chevalier, M.-L., Hilley, G., Tapponnier, P., Van DerWoerd, J., Liu-Zeng, J., Finkel, R.C.,

1165 Ryerson, F.J., Li Haibing, L., Liu, X., 2011. Constraints on the late Quaternary glaciations in

1166 Tibet from cosmogenic exposure ages of moraine surfaces. Quaternary Science Reviews 30, 528-

1167554.

1168

1169 Chinese Academy of Sciences, 1996. Physical Geography and Natural Resources in the Mount

1170 Nanjiabawa Region. Science Press, Beijing, pp. 1-210 (in Chinese).

1171

1172 Cogley, J.G. 2011. Present and future states of Himalaya and Karakoram glaciers. Annals of

1173 Glaciology 52, 69-73.

1174

1175 Clapperton, C., 1993. Quaternary Geology and Geomorphology of South America. Elsevier, 1176 Amsterdam.

1177

1178 Colgan, P.M., Munroe, J.S., Zhou, S., 2006. Cosmogenic radionuclide evidence for the limited

1179 extent of last glacial maximum glaciers in the Tanggula Shan of the central Tibetan Plateau.

1180 Quaternary Research 65, 336-339

1181

1182 Copland, L., Sylvestre, T., Bishop, M.P., Shroder, J.F., Seong, Y.B., Owen, L.A., Bush, A., Kamp,

1183 U., 2011. Expanded and recently increased glacier surging the Karakoram. Arctic, Alpine and

1184 Antarctic Research 43, 503-516.

1185

1186 Cronin, V.S., Johnson, W.P., Johnson, N.M., Johnson, G.D., 1989. Chronostratigraphy of the 1187 upper Cenozoic Bunthang sequence and possible mechanisms controlling base level in Skardu 
1188 intermontane basin, Karakoram Himalaya, Pakistan. Geological Society of America Special

1189 Paper 232, 295-309.

1190

1191 Dainelli, G., 1922. Studi sul glaciale Spedizone Italian de Filippi nell' Himalaia, Caracorume

1192 Turchestan/Cinese (1913-1914). Ser II, 3: Zanichelli, Bologna, 658 pp.

1193

1194 Dainelli, G. 1934. Studi sul Glaciale: Spedizone Italian de Filippi nel'Himalaia, Caracorum e

1195 Turchestan Cinese (1913-1914). Ser. II., 3: Zanichelli, Bologna, 658 pp.

1196

1197 Dainelli, G., 1935. La Series dei Terreni: Spedizione Ilaliana De Fillippi nell’Himalaia,

1198 Caracorum e Turchestan Cinese (1913-1914). Ser. II, 2: Zanichelli, Bologna, 230 pp.

1199

1200 De Terra, H., Paterson, T.T., 1939. Studies on the Ice Age in India and associated human

1201 cultures. Carnegie Institute of Washington Publications 493, 354 pp.

1202

1203 Denton, G.H., Karlén, 1973. Holocene climatic variations - their pattern and possible cause.

1204 Quaternary Research 3, 155-205.

1205

1206 Derbyshire, E., Li, J., Perrott, F.A., Xu, S., Waters, R.S., 1984. Quaternary glacial history of the

1207 Hunza valley Karakoram Mountains, Pakistan. In International Karakoram Project, Miller K.

1208 (ed), CambridgeUniversity Press: Cambridge; 456-495.

1209

1210 Derbyshire, E., 1981. Glacier regime and glacial sediment facies: a hypothetical framework for

1211 the Qinghai-Xizang Plateau. In: Proceedings of Symposium on Qinghai-Xizang (Tibet) Plateau,

1212 Beijing, China. Geological and Ecological studies of Qinghai-Xizang Plateau. Vol. 2, Science

1213 Press, Beijing, 1981, pp. 1649-1656. 
1215 Derbyshire, E., 1983. The Lushan Dilemma: Pleistocene glaciation south of the ChangJiang

1216 (Yangste River). Zeitschrift für Geomorphologie 27, 445-471.

1217

1218 Derbyshire, E., 1984. Sedimentological analysis of glacial and proglacial debris: a framework for 1219 the study of Karakoram glaciers. In: Miller, K.J. (Ed.), The International Karakoram Project, 1.

1220 Cambridge University Press, Cambridge, pp. 347-364.

1221

1222 Derbyshire, E., 1987. A history of the glacial stratigraphy in China. Quaternary Science Reviews $12236,301-314$

1224

1225 Derbyshire, E., 1996. Quaternary glacial sediments, glaciation style, climate and uplift in the

1226 Karakoram and northwest Himalaya: review and speculations. Palaeogeography,

1227 Palaeoclimatology, Palaeoecology 120, 147-157.

1228

1229 Derbyshire, E., Owen, L.A., 1990. Quaternary Alluvial Fans in the Karakoram Mountains. In:

1230 Rachocki, A.H., Church, M. (Eds.), Alluvial Fans: A field approach. John Wiley \& Sons Ltd., 1231 pp. 27-53.

1232

1233 Derbyshire, E., Owen, L.A., 1997. Quaternary glacial history of the Karakoram Mountains and 1234 Northwest Himalayas: a review. Quaternary International 38/39, 85-102.

1235

1236 Derbyshire, E., Shi, Y., Li, J., Zheng, B., Li, S., Wang, J., 1991. Quaternary glaciation of Tibet: 1237 the geological evidence. Quaternary Science Reviews 10, 485-510. 
1239 Desilets, D., Zreda, M., 2003. Spatial and temporal distribution of secondary cosmic-ray nucleon

1240 intensities and applications to in situ cosmogenic dating. Earth and Planetary Science Letters 206, $1241 \quad 21-42$.

1242

1243 Desilets, D., Zreda, M., 2006. Elevation dependence of $\operatorname{cosmogenic}{ }^{36} \mathrm{Cl}$ production in Hawaiian 1244 lava flows. Earth and Planetary Science Letters 246, 277-287.

1245

1246 Dortch, J.M., Owen, L.A., Haneberg, W.C., Caffee, M.W., Dietsch, C., Kamp, U., 2009. Nature

1247 and timing of mega-landslides in northern India. Quaternary Science Reviews 28, 1037-1056.

1248

1249 Dortch, J.M., Owen, L.A., Caffee, M.W., 2010a. Quaternary glaciation in the Nubra and Shyok

1250 valley confluence, northernmost Ladakh, India. Quaternary Research 74, 132-144.

1251

1252 Dortch, J. M., Owen, L. A., Caffee, M. W. \& Brease, P. 2010b. Late Quaternary glaciation and 1253 equilibrium line altitude variations of the McKinley River region, central Alaska Range.

1254 Boreas39, 233-246.

1255

1256 Dortch, J.M., Owen, L.A., Dietsch, C., Caffee, M.W., Bovard, K., 2011a. Episodic fluvial

1257 incision of rivers and rock uplift in the Himalaya and Transhimalaya. Journal of the Geological

1258 Society, London 168, 783-804.

1259

1260 Dortch, J.M., Owen, L.A., Schoenbohm, L.M., Caffee, M.W., 2011b. Asymmetrical erosion and 1261 morphological development of the central Ladakh Range, northern India. Geomorphology 135, 1262 167-180.

1263 
1264 Dortch, J.M.*, Owen, L.A., Caffee, M.W., Kamp, U., 2011. Catastrophic partial drainage of

1265 Pangong Tso, northern India and Tibet. Geomorphology 125, 109-121.

1266 Dortch, J.M., Owen, L.A., Caffee, M.W., 2013. Timing and climatic drivers for glaciation across

1267 semi-arid western Himalayan-Tibetan orogen. Quaternary Science Reviews, in revision.

1268

1269 Drew, F., 1873. Alluvial and lacustrine deposits and glacial records of the upper Indus basin; Part

1270 1, Alluvial deposits. Geological Society of London Quarterly Journal 29, 449-471.

1271

1272 Dunai, T.J., 2000. Scaling factors for production rates of in situ produced cosmogenic nuclides: a 1273 critical reevaluation. Earth and Planetary Science Letters 176, 157-169.

1274

1275 Duncan, C.C., Klein, A.J., Masek, J.G, Isacks, B.L., 1998. Late Pleistocene and modern

1276 glaciations in Central Nepal from digital elevation data and satellite imagery. Quaternary

1277 Research 49, 241-254.

1278

1279 Ehlers, J., Gibbard, P., (eds.) 2004. Quaternary glaciations - extent and chronologies. Part III:

1280 South America, Asia, Africa, Australia, Antarctica. Developments in Quaternary Science 2, 380

1281 pp.

1282

1283 Elhers, J., Gibbard, P., Hughes, P.D., (eds.) 2011, Quaternary Glaciations - Extent and

1284 Chronology: a closer look. Developments in Quaternary Science, volume 15, Elsevier,

1285 Amsterdam, $2^{\text {nd }}$ Edition, 929-942.

1286

1287 Eyles, N., Eyles, C.H., Miall, A.D., 1983. Lithofacies types and vertical profile models, An

1288 alternative approach to the description and environmental interpretation of glacial diamict and 
1289 diamictite sequences. Sedimentology 30, 393-410.

1290

1291 Fenton, C.R., Hermanns, R.L., Blikra, L.H., Kubik, P.W., Bryant, C., Niedermann, S., Meixner,

1292 Anette, Goethals, M.M., 2011. Regional ${ }^{10}$ Be production rate calibration for the past $12 \mathrm{ka}$

1293 deduced from the radiocarbon-dated GrǾtlandsura and Russenes rock avalanches at $69^{\circ} \mathrm{N}$,

1294 Norway. Quaternary Geochronology 6, 437-452.

1295

1296 Fielding, E., Isacks, B., Barazangi, M., Duncan, C., 1994. How flat is Tibet? Geology 22, 163-

$1297 \quad 167$.

1298

1299 Finkel, R.C., Owen, L.A., Barnard, P.L., Caffee, M.W., 2003. Beryllium-10 dating of Mount

1300 Everest moraines indicates a strong monsoonal influence and glacial synchroniety throughout the

1301 Himalaya. Geology 31, 561-564.

1302

1303 Finkel, R.C., Owen, L.A., Barnard, P.L., Caffee, M.W., 2003. Beryllium-10 dating of Mount

1304 Everest moraines indicates a strong monsoonal influence and glacial synchroneity throughout the

1305 Himalaya. Geology 31, 561-564.

1306

1307 Fort, M., 1986. Glacial extension and catastrophic dynamics along the Annapurna front, Nepal

1308 Himalaya. In: Kuhle, M. (Ed.) Internationales über Tibet und Hochasien vom 8.-11. Oktober

13091985 im Geographischen Institut der Universität Göttingen, Verlag Erich Goltze GmbH \& Co.

1310 KG, Göttingen, 105-125.

1311

1312 Fort, M., Derbyshire, E., 1988. Some characteristics of tills in the Annapurna Range, Nepal. In:

1313 Chen, E. (Ed.), Proceedings of the Second Conference on the palaeoenvironment of East Asia 
1314 from the Mid-Tertiary. Vol. 1 Geology, Sea level changes, palaeoclimatology and palaeobotany.

1315 University of Hong Kong, Hong Kong, 195-214.

1316

1317 Fort, M., 2003. Are high altitude, lava stream-like, debris mixtures all rock glaciers? A

1318 perspective from the Western Himalaya. Zeitschrift für Geomorphology 130, 11-29.

1319

1320 Frenzel, B., 1960. Die Vegetations- und Landschaftszonen Nordeurasiens während der letzten

1321 Eiszeit und während der Postglazialen Warmezeit. Akademie der Wissenschaften und der

1322 Literatur in Mainz, Abhandlungen der Mathematisch-Naturwissenschaftlichen Klasse 13, 937-

13231099.

1324

1325 Fu, P, Stroeven, A.P., Harbor, J.M., Hättestrand, C., Heyman, J., Caffee, M.W., Zhou, L. 2013.

1326 Paleoglaciation of Shaluli Shan, southeastern Tibetan Plateau. Quaternary Science Reviews 64, 121-

$1327 \quad 135$.

1328

1329 Fuchs, M., Owen, L.A., 2008. Luminescence dating of glacial and associated sediments: review, 1330 recommendations and future directions. Boreas 37, 636-659.

1331

1332 Fujita, K., Nakawo, M., Fujii, Y., Paudyal, P., 1997. Changes in glaciers in Hidden Valley,

1333 Mukut Himal, Nepal Himalayas, from 1974 to 1994. Journal of Glaciology 43, 583-588.

1334

1335 Fushimi, H., 1977. Glaciations in the Khumbu Himal (1). Seppyo 39, 60-67.

1336

1337 Fushimi, H., 1978. Glaciations in the Khumbu Himal (2). Seppyo 40, 71-77. 1338 
1339 Gayer, E., Lavé, J., Pik, R., France-Lanord, C., 2006. Monsoonal forcing of Holocene glacier

1340 fluctuations in Ganesh Himal (central Nepal) constrained by cosmogenic ${ }^{3} \mathrm{He}$ exposure ages of 1341 garnets. Earth Planetary Science Letters 252, 275-288.

1342

1343 Geyh, M.A., Rothlisberger, F. and Gellantly, A.F., 1985. Reliability tests of C14 dates from 1344 paleosol in glacier enviornments. Zeitschrift für Gletscherkunde und Glazialgeologie, 21, 275$1345 \quad 281$

1346

1347 Gibbons, A.B., Megeath, J.D., Pierce, K.L., 1984. Probability of moraine survival in a succession 1348 of glacial advances. Geology 12, 327-330.

1350 Gillespie, A., Molnar, P., 1995. Asynchronous maximum advances of mountain and continental 1351 glaciers. Reviews of Geophysics 33, 311-364.

1352 Goehring, B.M., Lohne, Ǿ.S., Mangerud, J., Svendsen, J.I., Gyllencreutz, R., Schaefer, J., Finkel,

1353 R., 2012. Late glacial and Holocene ${ }^{10} \mathrm{Be}$ production rates for western Norway. Journal of

1354 Quaternary Science 27, 89-96.

1355

1356 Gosse, J., Klein, J., Evenson, E.B., Lawn, B., Middleton, R., 1995. Beryllium-10 dating of the 1357 duration and retreat of the last Pinedale glacial Sequence. Science 228, 1329-1333.

1358

1359 Graf, A.A., Strasky, S., Zhao, Z.Z., Akçar,N., Ivy-Ochs, S., Kubik, P.W., Christl, M., Kasper,

1360 H.U., Wieler, R., Schlu $\square$ chter, C., 2008. Glacier extension on the eastern Tibetan Plateau in

1361 response to MIS 2 cooling, with a contribution to ${ }^{10} \mathrm{Be}$ and ${ }^{21} \mathrm{Ne}$ methodology. In: Strasky,

1362 S., Glacial response to global climate changes: cosmogenic nuclide chronologies from high and

1363 low latitudes. PhD Thesis, ETH Zu $\square$ rich. 
1365 Grove, J.M., 2004. The Little Ice Age: ancient and modern. Volume 1, 2nd edition. Routledge, 1366 London, $432 \mathrm{p}$.

1367

1368 Guggenberger, G., Bäumler, R., Zech, W., 1998. Weathering of soils developed in eolian material 1369 overlying glacial deposits in Eastern Nepal. Soil Science 163, 325-337.

1370

1371 Haeberli, W., Bosch, H., Scherler, K., Ostrem, G., Wallen, C.C., 1989. World Glacier Inventory:

1372 Status 1988. Compiled by the World Glacier Monitoring Service, IAHS-UNEP-UNESCO:

1373 Wallingford, UK.

1374

1375 Hallet, B., Putkonen, J., 1994. Surface dating of dynamic landforms: young boulders on aging 1376 moraines. Science 265, 937-940.

1377

1378 Hedrick, K.A., Seong, Y.B., Owen, L.A., Caffee, M.C., Dietsch, C., 2011. Towards defining the 1379 transition in style and timing of Quaternary glaciation between the monsoon-influenced Greater 1380 Himalaya and the semi-arid Transhimalaya of Northern India. Quaternary International 236, 21138133.

1382

1383 Heimsath, A.M., McGlynn, R., 2008. Quantifying periglacial erosion in the Nepal high Himalaya. 1384 Geomorphology 97, 5-23.

1385

1386 Hewitt, K., 1969. Glacier surges in the Karakoram Himalaya (Central Asia). Canadian Journal of 1387 Earth Sciences 6, 1009-1018.

1388 
1389 Hewitt, K., 1998. Catastrophic landslides and their effects on the Upper Indus streams,

1390 Karakoram Himalaya, northern Pakistan. Geomorphology 26, 47-80.

1391

1392 Hewitt, K., 1999. Quaternary moraines vs catastrophic avalanches in the Karakoram Himalaya, 1393 northern Pakistan. Quaternary Research 51, 220-237.

1395 Hewitt, K., 2005. The Karakoram anomaly? Glacier Expansion and the 'Elevation Effect,'

1396 Karakoram Himalaya. Mountain Research and Development 25, 332-340.

1397

1398 Hewitt, K., Gosse, J., Clague, J.J., 2011. Rock avalanches and the pace of late Quaternary

1399 development of river valleys in the Karakoram Himalaya. Geological Society of America Bulletin $1400 \quad 123,1836-1850$.

1401

1402 Heyman, J., Hattestrand, C., Stroeven, A.P., 2008. Glacial geomorphology of the Bayan Har 1403 sector of the NE Tibetan plateau. Journal of Maps, 2008, 42-62.

1404

1405 Heyman, J., Stroeven, A.P., Alexanderson, H., Hättestrand, C., Harbor, J., Li, Y.K., Caffee, 1406 M.W., Zhou, L.P., Veres, D., Liu, F., Machiedo, M., 2009. Palaeoglaciation of Bayan Har Shan, 1407 northeastern Tibetan Plateau: Glacial geology indicates maximum extents limited to ice cap and 1408 ice-field scales. Journal of Quaternary Science 24, 710-727.

1409

1410 Heyman, J., Stroeven, A.P., Caffee, M.W.,Hättestrand, C., Harbor, J., Li, Y.K., Alexanderson, H., 1411 Zhou, L.P., Hubbard, A., 2010. Palaeoglaciology of Bayan Har Shan, NE Tibetan Plateau:the 1412 case of a missing LGM expansion, In: Heyman, J., Palaeoglaciology of the northeastern Tibetan 1413 Plateau. PhD thesis, Stockholm University. 
1415 Heyman, J., Stroeven, A.P., Caffee, M.W., Hättestrand, C., Harbor, J.M., Li, Y.K., Alexanderson, 1416 H., Zhou, L.P., Hubbard, A., 2011a. Palaeoglaciology of Bayan Har Shan, NE Tibetan Plateau:

1417 exposure ages reveal a missing LGM expansion. Quaternary Science Reviews 30, 1988-2001. 1418

1419 Heyman, J., Stroeven, A., Harbor, J., Caffee, M.W. 2011b. Too young or too old: evaluating 884 1420 cosmogenic exposure dating based on an analysis of compiled boulder exposure 885 ages. Earth 1421 and Planetary Science Letters 302, 71-80.

1422

1423 Holmes, J.A., Street-Perrott, F.A. 1989: The Quaternary Glacial History of Kashmir, North-West

1424 Himalaya: A Revision of de Terra and Paterson's Sequence. Zeitscrift für Geomorphologie 76,

$1425 \quad 195-212$.

1426

1427 Hövermann J, Lehmkuhl F, Pörtge K-H., 1993a. Pleistocene glaciations in Eastern and Central

1428 Tibet- Preliminary results of the Chinese-German joint expeditions. Zeitscrift für

1429 Geomorphologie 92, 85-96.

1430

1431 Hövermann, J., Lehmkuhl, F., Süssenberger, H., 1993b. Neue Befunde zur Paläoklimatologie

1432 Nordafrikas und Zentralasiens. Abhandlungen der Braunschweigischen Wissenschaftlichen

1433 Gesellschaft 43, 127-150.

1434

1435 Hughes, P.D., Gibbard, P.L., Woodward, J.C., 2005. Quaternary glacial records in mountain 1436 regions: a formal stratigraphical approach. Episodes 28, 85-92.

1437

1438 Intergovernmental Panel on Climate Change, 2007. Climate Change 2007: Impacts, Adaptations

1439 and Vulnerability. Parry, M., Canziani, O., Palutikof, J., Van der Linden, P., Hanson, C. (Eds.), 
1440 Contribution of Working Group II to the Fourth Assessment Report of the Intergovernmental

1441 Panel on Climate Change. Cambridge University Press, Cambridge, UK, 976 pp.

1442 Ivy-Ochs, S., Kerschner, H., Schlüchter, C. 2007. Cosmogenic nuclides and the dating of

1443 lateglacial and EarlyHolocene glacier variations: The Alpine perspective. Quaternary

1444 international 164-165, 53-63.

1445

1446 Iwata, S.J., Jiao, K.Q.. 1993. Fluctuations of the Zepu Glacier in late Holocene Epoch, the eastern

1447 Nyainqentanglha Mountains. In: Yao T.D., Ageda, Y. (Eds.) Glaciation Climate and Environment

1448 in Qinghai-Tibet Plateau, Science Press, Beijing, 130-138.

1449

1450 Iwata S.J., Naramaa, C.K., Karma, 2002. Three Holocene and late Pleistocene glacial stages

1451 inferred from moraines in the Lingshi and Thanza village areas, Bhutan. Quaternary International $145297 / 98,69-78$.

1453

1454 Iwata, S., Naito, N., Narama, C., 2003. Rock glaciers and the lower limit of permafrost in the

1455 Bhutan Himalayas. Zeitschrift für Geomorphologie 130, 129-143.

1456

1457 Jiao, K.Q., Iwata, S.J., 1993. The glacier variation in Kunlun pass area and southeast Tibet area

1458 since last glaciation. In: Yao, T.D., Ageda, Y. (Eds.), Glaciation Climate and Environment in

1459 Qinghai-Tibet Plateau, Science Press, Beijing, 120-129.

1460

1461 Jiao, K.Q., Shen, Y.P., 2006. Quaternary glaciations in Tanggulha Mountains. In: Shi, Y.F., Su,

1462 Z., Cui, Z.J. (Eds.) The Quaternary glaciations and environmental variations in China. Science

1463 and Technology Press of Hebei Province, Shijiazhuang, 326-356.

1464 
1465 Jiao, K.Q., Zheng, B.X., 2006. Quaternary glaciations in Kunlun Mountains. In: Shi, Y.F., Su, Z.,

1466 Cui, Z.J., (Eds.), The Quaternary Glaciations and Environmental variations in China, Science and

1467 Technology Press

1468 of Hebei Province, Shijiazhuang, 326-356.

1469

1470 Jiao, K., Iwata, S., Yao, T., Jing, Z., Li, Z., 2005. Variation of Zepu Glacier and environmental

1471 change in the eastern Nyainqentanglha Range since $3.2 \mathrm{ka}$ BP. Journal of Glaciology and

1472 Geocryology 27, 74-79.

1473

1474 Kamp, U., Owen, L.A., 2011. Late Quaternary Glaciation of Northern Pakistan. . In: Elhers, J.,

1475 Gibbard, P. and Hughes, P.D. (Eds.), Quaternary Glaciations - Extent and Chronology: a closer

1476 look. Developments in Quaternary Science, volume 15, Elsevier, Amsterdam, 909-927.

1477 Kaplan, M.R., Hein, A.S., Hubbard, A., Lax, S.M., 2009. Can glacial erosion limit he extent of 1478 glaciation? Geomorphology 103, 172-179.

1479

1480 Kaplan, M.R.,Strelin, J.A., Schaefer, J.M., Denton, G.H., finkel, R.C., Schwartz, R., Putnam,

1481 A.E., Vandergoes, M.J., Goehring, B.M., Travis,S.G., 2011. In-Situ cosmogenic 10Be

1482 production rate at Lago Argentino, Patagonia: Implications for late-glacial climate chronology.

1483 Earth and planetary Science Letters 309, 21-32.

1484

1485 Klute, F., 1930. Verschiebung der Klimagebiete der letzten Eiszeit. Petermanns Mitteilungen

1486 Ergänzungsheft 209, 166-182.

1487

1488 Kong, P., Fink, D., Na, C.G., Huang, F.X., 2009a. Late Quaternary glaciation of the Tianshan,

1489 central Asia, using cosmogenic ${ }^{10}$ Be surface exposure dating. Quaternary Research 72, 229-233. 
1491 Kong, P., Na, C.G., Fink, D., Zhao, X.T., Xiao, W., 2009b. Moraine dam related to late

1492 Quaternary glaciation in the Yulong Mountains, southwest China, and impacts on the Jinsha

1493 River. Quaternary Science Reviews 28, 3224-3235

1494

1495 Koppes, M., Gillespie, A.R., Burke, R.M., Thompson, S.C., Stone, J., 2008. Late Quaternary

1496 glaciation in the Kyrgyz Tien Shan. Quaternary Science Reviews 27, 846-866.

1497

1498 Kuhle, M., 1985. Ein subtropisches Inlandeis als Eiszeitauslöser, Südtibet un Mt. Everest

1499 expedition 1984. Georgia Augusta, Nachrichten aus der Universität Gottingen, May, 1-17.

1500

1501 Kuhle, M., 1986. The upper limit of glaciation in the Himalayas. GeoJournal 13, 331-346.

1502

1503 Kuhle, M., 1987. The Problem of a Pleistocene Inland Glaciation of the Northeastern Qinghai-

1504 Xizang Plateau. In Reports of the Qinghai- Xizang (Tibet) Plateau, Hövermann J, Wang W. (eds).

1505 Beijing; 250-315.

1506

1507 Kuhle, M., 1988a. Geomorphological findings on the built-up of Pleistocene glaciation in

1508 Southern Tibet and on the problem of inland ice. GeoJournal 17, 457-512.

1509

1510 Kuhle, M., 1988b. Topography as a fundamental element of glacial systems. GeoJournal 17, 545-

1511568.

1512

1513 Kuhle, M., 1990a. The cold deserts of high Asia (Tibet and contiguous mountains). GeoJournal $1514 \quad 20,319-323$. 
1516 Kuhle, M., 1990b. Ice marginal ramps and alluvial fans in semiarid mountains: convergence and

1517 difference. In: Rachocki AH, Church M. (Eds.), Alluvial Fans: a field approach, John Wiley and

1518 Sons: Chichester; 55-68.

1519

1520 Kuhle, M., 1991. Observations supporting the Pleistocene inland glaciation of High Asia.

1521 GeoJournal 25, 131-231.

1522

1523 Kuhle, M., 1993. A short report of the Tibet excursion 14-A, Part of the XIII INQUA Congress

15241991 in Beijing. GeoJournal 29, 426-427.

1525

1526 Kuhle, M., 1995. Glacial isostatic uplift of Tibet as a consequence of a former ice sheet.

1527 GeoJournal 37, 431-449.

1528

1529 Kuhle, M., 2011. The High Glacial (Last Ice Age and Last Glacial Maximum) ice cover of high

1530 and Central Asia, with critical review of some recent OSL and TCN dates. In: Elhers, J., Gibbard,

1531 P. and Hughes, P.D. (Eds.), Quaternary Glaciations - Extent and Chronology: a closer look.

1532 Developments in Quaternary Science, volume 15, Elsevier, Amsterdam, $2^{\text {nd }}$ Edition, 943-965.

1533

1534 Lal, D., 1991. Cosmic ray labeling of erosion surfaces: in situ nuclide production rates and

1535 erosion models. Earth and Planetary Science Letters 104, 429-439.

1536

1537 Lasserre, C., Gaudemer, Y., Tapponnier, P., Mériaux, A.-S., Van der Woerd, J., Yuan, D.,

1538 Ryerson, F.J., Finkel, R.C., Caffee, M.W., 2002. Fast late Pleistocene slip rate on the Leng Long

1539 Ling segment of the Haiyuan fault, Qinghai, China. Journal of Geophysical Research 107, B11,

15402276. 
1542 Lee, S.Y., Seong, Y.B., Owen, L.A., Murari, M.K., Lim, H.S., Yoon, H.I., You, K.-C, 2013. Late

1543 Quaternary glaciation in the Nun-Kun massif, northwestern India. Boreas, in press.

1544

1545 Lehmkuhl, F., 1995. Geomorphologische Untersuchungen zum Klima des Holoza“ns und

1546 Jungpleistoza“ns Osttibets. Göttinger Geographische Abhandlungen 102, 1-184.

1547

1548 Lehmkuhl, F., 1997. Late Pleistocene, Late-glacial and Holocene glacier advances on the Tibetan

1549 Plateau. Quaternary International 38/39, 77-83.

1550

1551 Lehmkuhl, F., 1998. Extent and spatial distribution of Pleistocene glaciations in Eastern Tibet.

1552 Quaternary International 45/46, 123-134.

1553

1554 Lehmkuhl, F., Lui S., 1994. An outline of physical geography including Pleistocene glacial

1555 landforms of Eastern Tibet (Provinces Sichuan and Qinghai). GeoJournal 34, 7-30.

1556

1557 Lehmkuhl, F., Owen L.A., 2005. Late Quaternary glaciation of Tibet and the bordering

1558 mountains: a review. Boreas 34, 87-100.

1559

1560 Lehmkuhl, F., Owen, L.A., Derbyshire, E., 1998. Late Quaternary glacial history of northeastern

1561 Tibet. Quaternary Proceedings 6, 121-142.

1562

1563 Lehmkuhl, F., Klinge, M., Stauch, G. 2004. The extent of Late Pleistocene Glaciations in the

1564 Altai and Khangai Mountains. - In: Ehlers, J. \& P.L. Gibbard (Eds.): Quaternary glaciations -

1565 extent and chronologies, Part III: South America, Asia, Africa, Australia, Antarctica, p.243-254.

1566 Elsevier, Oxford .

1567 
1568 Leuschner, D.C., Sirocko, F., 2003. Orbital insolation forcing of the Indian monsoon - A motor

1569 for global climate change. Paleogeography, Paleoclimatology and Paleoecology 197, 83-95.

1570

1571 Li, Y., Harrison, S.P., 2008. Simulations of the impact of orbital forcing and ocean on the Asian

1572 summer monsoon during the Holocene. Global and Planetary Change 60, 505-522.

1573

1574 Li, S.J., Jiao, K.Q., 1990. Glacier variation on the south slope of west Kunlun Mountains since

$157530000{ }^{14} \mathrm{C}$ yr BP. (Chinese with English summary). Journal of Glaciology and Geocryology 12, 1576 311-318.

1577

1578 Li, S.J., Li, S.D., 1992. Quaternary glacial and environmental changes in the region of Hoh Xil,

1579 Qinghai Province. (Chinese with English summary). Journal of Glaciology and Geocryology 14, 1580 316-324.

1581

1582 Li, J.J., Derbyshire, E., Street-Perrott, F.A., Xu, S.Y., Waters, R.S., 1984. Glacial and paraglacial 1583 sediments of the Hunza valley, north-west Pakistan: a preliminary analysis. In: Miller, K. (Ed.), 1584 The International Karakoram Project, Cambridge University Press: Cambridge, 496-535.

1585

1586 Li, J.J., Zheng, B.X., Yang, X.J., 1986. Glacier in Tibet. Science Press, Beijing, 1-275.

1587

1588 Li, B., Li, J., Cui, Z., (eds.) 1991. Quaternary glacial distribution map of Qinghai-Xizang (Tibet)

1589 Plateau 1:3,000,000. Shi Y. (Scientific Advisor), Quaternary Glacier, and Environment Research 1590 Center, Lanzhou University.

1592 Lifton, N.A., Bieber, J.W., Clem, J.M., Duldig, M.L., Evenson, P., Humble, J.E., Pyle, R., 2005.

1593 Addressing solar modulation and long-term uncertainties in scaling secondary cosmic rays for in 
1594 situ cosmogenic nuclide applications. Earth and Planetary Science Letters 239, 140-161.

1595

1596 Lisiecki, L.E., Raymo, M.E., 2005. A Pliocene-Pleistocene stack of 57 globally distributed

1597 benthic $\delta^{18} \mathrm{O}$ records. Paleoceanography 20, PA1003, DOI: 10.1029/2004PA001071

1598

1599 Mann, D.H, Sletten, R.S, Reanier, R.E. 1996. Quaternary glaciation of the Rongbuk Valley,

1600 Tibet. Journal of Quaternary Science 11, 267-280.

1601

1602 Martinson, D.G., Pisias, N.G., Hays, J.D., Imbrie, J., Moore, T.C., Shackleton, N.J., 1987. Age

1603 dating and the orbital theory of ice ages: Development of a high resolution 0 to 300,000-year

1604 chronology. Quaternary Research 27, 1-29.

1605

1606 Mayer, C., Lambrecht, A., Belò, M., Smiraglia, C., and Diolaiuti, G., 2006: Glaciological

1607 characteristics of the ablation zone of Baltoro glacier, Karakoram, Pakistan. Annals of Glaciology

1608 43: 123-131.

1609

1610 Mayewski, P.A., Jeschke, P.A., 1979. Himalayan and Trans-Himalayan glacier fluctuations since

1611 AD 1812. Arctic and Alpine Research 11, 267-287.

1612

1613 Mayewski, P.A., Pregent, G.P., Jeschke, P.A., Ahmad, N., 1980. Himalayan and Trans

1614 Himalayan glacier fluctuations and the South Asian Monsoon record. Arctic and Alpine Research $1615 \quad 12,171-182$.

1616

1617 Mayewski, P.A., Rohling, E.E., Stager, C.J., Karlén, W., Maasch, A., Meeker, L.D., Meyerson,

1618 E.A., Gasse, F., Van Kreveld, S., Holmgren, K., Lee-Thorp, J., Rosqvist, G., Rack, F., 
1619 Staubwasser, M., Schneider, R.R., Steig, E.J., 2004. Holocene climate variability. Quaternary

1620 Research 62, 243-255.

1621

1622 Mériaux, A.-S., Ryerson, F.J., Tapponnier, P., Van der Woerd, J., Finkel, R.C., Xu, X., Xu, Z.,

1623 Caffee, M.W. 2004. Rapid slip along the central Altyn Tagh Fault: morphochronologic evidence

1624 from Cherchen He and Sulamu Tagh. Journal of Geophysical Research 109, B06401.

1625

1626 Meyer, M.C., Hofmann, Ch.-Ch., Gemmell, A.M.D., Haslinger, E., Häusler, H., Wangda, D.,

1627 2009. Holocene glacier fluctuations and migration of Neolithic yak pastoralists into the high

1628 valleys of northwest Bhutan. Quaternary Science Reviews 28, 1217-1237.

1629

1630 Morén, B., Heyman, J., Stroeven, A.P., 2011. Glacial geomorphology of the central Tibetan

1631 Plateau. Journal of Maps 2011, 115-125.

1632

1633 Muller, F., 1980. Present and late Pleistocene equilibrium line altitudes in the Mt. Everest

1634 region-An application of the glacier inventory. World Glacier Inventory 126, 75-94.

1635

1636 Murari, M.K., Owen, L.A., Dortch, J.M., Caffee, M.W., Dietsch, C., Fuchs, M., Haneberg, W.,

1637 Sharma, M.C., Townsend-Small, A. 2013. Timing and climatic drivers for glaciation across

1638 monsoon-influenced regions of the Himalayan-Tibetan orogen. Quaternary Science Reviews,

1639 in review.

1640

1641 Narama, C., 2002. Late Holocene variation of the Raigorodskogo Glacier and climate change in

1642 the Pamir-Alai, central Asia. Catena 48, 21-37.

1643 
1644 Narama, C., Kondo, R., Tsukamoto, S., Kajiura, T., Ormukov, C., Abdrakhmatov, K., 2007. OSL

1645 dating of glacial deposits during the Last Glacial in the Terskey-Alatoo Range, Kyrgyz Republic.

1646 Quaternary Geochronology 2, 249-254.

1647

1648 Narama, C., Kondo, R., Tsukamoto, S., Kajiura, T., Duishonakunov, M., Abdrakhmatov, K.,

1649 2009. Timing of glacier expansion during the Last Glacial in the inner Tien Shan, Yrgyz Republic

1650 by OSL dating. Quaternary International 199, 147-156.

1651

1652 NGRIP members, 2004. High-resolution record of Northern Hemisphere climate extending into

1653 the last interglacial period. Nature 431, 147-151.

1654

1655 Norin, E., 1925. Preliminary notes on the Late Quaternary glaciation of the North Western

1656 Himalaya. Geografiska Annaler 7, 165-194.

1657

1658 Norton, K.P., Abbühl, L.M., Schlunegger, F., 2010. Glacial conditioning as an erosional driving

1659 force in the Central Alps. Geology 38, 655-658.

1660

1661 Ono, Y., 1984. Annual moraine ridges and recent fluctuation of Yala (Dakpatsen) Glacier,

1662 Langtang Himal. In: Higuchi, K. (Ed.) Glacier studies in Langtang Valley. Data Center for

1663 Glacier Research, Japan Society for Snow and Ice 2, 73-83.

1664

1665 Ono, Y., 1985. Recent fluctuations of the Yala (Dakpatsen) Glacier, Langtang Himal,

1666 reconstructed from Annual moraine ridges. Zeitschrift für Gletscherkunde und Glaziaklgeologie

$166721,251-258$.

1668 
1669 Ono, Y., 1986. Glacial fluctuations in the Langtang valley Nepal Himalaya. In: Kuhle, M. (Ed.)

1670 Internationales über Tibet und Hochasien vom 8.-11. Oktober 1985 im Geographischen Institut

1671 der Universität Göttingen, Verlag Erich Goltze GmbH \& Co. KG, Göttingen, 31-38.

1672

1673 Ono, Y., Liu, D., Zhao, Y., 1997. Paleoenvironments of Tibetan Plateau from glacial fluctuations

1674 in the northern foot of the West Kunlun Mountains. Journal of Geography 106, 184-198 (In

1675 Japanese).

1676 Osmaston, H., 1994. The geology, geomorphology and Quaternary history of Zangskar. In:

1677 Crook, J., Osmaston, H. (Eds.) Himalayan Buddhist Villages. University of Bristol Press, UK, 1-

167836.

1679

1680 Owen, L.A., 1988. Wet-sediment deformation of Quaternary and Recent sediments in the Skardu

1681 Basin, Karakoram Mountains, Pakistan. In: Croots, D. (Ed.) Glaciotectonics, A. A. Balkema,

1682 Rotterdam, pp. 123-147.

1683

1684 Owen, L.A., 1991. Mass movement deposits in the Karakoram Mountains: their sedimentary

1685 characteristics, recognition and role in Karakoram landform evolution. Zeitschrift für

1686 Geomorphologie 35, 4, 401-424.

1687

1688 Owen, L.A., 2009. Latest Pleistocene and Holocene glacier fluctuations in the Himalaya and

1689 Tibet. Quaternary Science Reviews 28, 2150-2164.

1690

1691 Owen, L.A., 2010. Landscape development of the Himalayan-Tibetan orogen: a review. Special

1692 Publication of the Geological Society of London 338, 389-407.

1693 
1694 Owen, L.A., 2011. Quaternary glaciation of Northern India. In: Elhers, J., Gibbard, P. and

1695 Hughes, P.D. (Eds.), Quaternary Glaciations - Extent and Chronology: a closer look.

1696 Developments in Quaternary Science, volume 15, Elsevier, Amsterdam, $2^{\text {nd }}$ Edition, 929-942.

1697

1698 Owen, L.A., 2013. Late Quaternary glaciations in Highland Asia. In: Scott E.A (Ed.)

1699 Encyclopedia of Quaternary Science, Vol. 2, pp. 236-244. Elsevier, Amsterdam.

1700

1701 Owen, L.A., Benn, D.I., 2005. Equilibrium-line altitudes of the Last Glacial Maximum for the

1702 Himalaya and Tibet: an assessment and evaluation of results. Quaternary International 138/139, 1703 55-78.

1704

1705 Owen, L.A., Derbyshire, E., 1988. Glacially deformed diamictons in the Karakoram Mountains,

1706 Northern Pakistan. In: Croots, D. (Ed.) Glaciotectonics, A. A. Balkema, Rotterdam, pp. 149-176.

1707

1708 Owen, L.A., Derbyshire, E., 1989. The Karakoram glacial depositional system. Zeitschrift für

1709 Geomorphologie 76, 33-74.

1710

1711 Owen, L.A., England, J., 1998. Observations on rock glaciers in the Himalayas and Karakoram

1712 Mountains of northern Pakistan and India. Geomorphology, 26, 199-213.

1713

1714 Owen, L.A., Benn, D.I., Derbyshire, E., Evans, D.J.A., Mitchell, W.A., Thompson, D.,

1715 Richardson, S., Lloyd, M., Holden, C., 1995. The geomorphology and landscape evolution of the 1716 Lahul Himalaya, Northern India. Zeitschrift für Geomorphologie 39, 145-174.

1717 
1718 Owen, L.A., Derbyshire, E., Richardson, S., Benn, D.I., Evans, D.J.A., Mitchell, W.A., 1996. The

1719 Quaternary glacial history of the Lahul Himalaya, Northern India. Journal of Quaternary Science

$1720 \quad 11,25-42$.

1721

1722 Owen, L.A., Mitchell, W., Bailey, R.M., Coxon, P., Rhodes, E., 1997. Style and timing of

1723 Glaciation in the Lahul Himalaya, northern India: a framework for reconstructing late Quaternary

1724 palaeoclimatic change in the western Himalayas. Journal of Quaternary Science 12, 83-109.

1725

1726 Owen, L.A., Scott, C.H., Derbyshire, E., 2000. The Quaternary glacial history of Nanga Parbat.

1727 Quaternary International 65/66, 63-79.

1728

1729 Owen, L.A., White, B., Rendell, H., Derbyshire, E., 1992. Loessic silts in the western Himalayas:

1730 their sedimentology, genesis and age. Catena 19, 493-509.

1731

1732 Owen, L.A. Gualtieri, L., Finkel, R.C., Caffee, M.W., Benn, D.I., Sharma, M.C., 2001.

1733 Cosmogenic radionuclide dating of glacial landforms in the Lahul Himalaya, Northern India:

1734 defining the timing of Late Quaternary glaciation. Journal of Quaternary Science 16, 555-563.

1735

1736 Owen, L.A., Finkel, R.C., Caffee, M.W., Gualtieri, L., 2002a. Timing of multiple glaciations

1737 during the Late Quaternary in the Hunza Valley, Karakoram Mountains, Northern Pakistan:

1738 defined by cosmogenic radionuclide dating of moraines. Geological Society of America Bulletin $1739114,593-604$.

1740

1741 Owen, L.A., Kamp, U., Spencer, J.Q., Haserodt, K., 2002b. Timing and style of Late Quaternary

1742 glaciation in the eastern Hindu Kush, Chitral, northern Pakistan: a review and revision of the 
1743 glacial chronology based on new optically stimulated luminescence dating. Quaternary

1744 International 97-98, 41-56.

1745

1746 Owen, L.A., Finkel, R.C., Caffee, M.W., 2002d. A note on the extent of glaciation throughout the 1747 Himalaya during the global Last Glacial Maximum. Quaternary Science Reviews 21, 147-157. 1748

1749 Owen, L.A., Finkel, R.C., Ma, H., Spencer, J.Q., Derbyshire, E., Barnard, P.L., Caffee, M.W., 1750 2003a. Timing and style of Late Quaternary glaciations in NE Tibet. Geological Society of 1751 America Bulletin, 11, 1356-1364.

1752

1753 Owen, L.A., Ma Haizhou, Derbyshire, E., Spencer, J.Q., Barnard, P.L., Zeng Yong Nian, Finkel, 1754 R.C., Caffee, M.W., 2003b. The timing and style of Late Quaternary glaciation in the La Ji 1755 Mountains, NE Tibet: evidence for restricted glaciation during the latter part of the Last Glacial. 1756 Zeitschrift für Geomorphologie, 130, 263-276.

1757

1758 Owen, L.A., Spencer, J.Q., Ma, H., Barnard, P.L., Derbyshire, E., Finkel, R.C., Caffee, M.W., 1759 Zeng Yong Nian, 2003c. Timing of Late Quaternary glaciation along the southwestern slopes of 1760 the Qilian Shan. Boreas 32, 281-291.

1761

1762 Owen, L.A., Finkel, R.C., Barnard, P.L., Ma, H., Asahi, K., Caffee, M.W., Derbyshire, E., 2005.

1763 Climatic and topographic controls on the style and timing of Late Quaternary glaciation

1764 throughout Tibet and the Himalaya defined by ${ }^{10} \mathrm{Be}$ cosmogenic radionuclide surface exposure 1765 dating. Quaternary Science Reviews 24, 1391-1411.

1766 
1767 Owen, L.A., Caffee, M., Bovard, K., Finkel, R.C., Sharma, M., 2006a. Terrestrial cosmogenic 1768 surface exposure dating of the oldest glacial successions in the Himalayan orogen. Geological 1769 Society of America Bulletin 118, 383-392.

1770

1771 Owen, L.A.. Finkel, R. C., Ma Haizhou, Barnard, P.L., 2006b. Late Quaternary landscape

1772 evolution in the Kunlun Mountains and Qaidam Basin, Northern Tibet: a framework for

1773 examining the links between glaciation, lake level changes and alluvial fan formation. Quaternary

1774 International 154-155, 73-86.

1775

1776 Owen, L.A., Caffee, M.W., Finkel, R.C., Seong, B.S., 2008a. Quaternary glaciation of the

1777 Himalayan-Tibetan orogen. Journal of Quaternary Science 23, 513-532.

1778

1779 Owen, L.A., Kamp, U., Khattak, G.A., Harp, E.L., Keefer, D.K., Bauer, M.A., 2008b. Landslides

1780 triggered by the October 8, 2005, Kashmir Earthquake. Geomorphology 94, 1-9.

1781

1782 Owen, L.A., Robinson, R., Benn, D.I., Finkel, R.C., Davis, N.K., Yi, C., Putkonen, J., Li, D., 1783 Murray, A.S., 2009. Quaternary glaciation of Mount Everest. Quaternary Science Reviews 28, $1784 \quad 1412-1433$.

1785

1786 Owen, L.A., Yi, C., Finkel, R.C., Davis, N., 2010. Quaternary glaciation of Gurla Mandata 1787 (Naimon'anyi). Quaternary Science Reviews 29, 1817-1830.

1788

1789 Owen, L.A., Chen, J., Hedrick, K.A., Caffee, M.W., Robinson, A., Schoenbohm, L.M., Zhaode, 1790 Y., Li, W., Imrecke, D., Liu, J., 2012. Quaternary glaciation of the Tashkurgan Valley, Southeast 1791 Pamir. Quaternary Science Reviews 47, 56-72.

1792 
1793 Pendersen, V.K., Egholm, D.L., 2013. Glaciations in response to climate variations

1794 preconditioned by evolving topography. Nature 493, 206-210.

1795

1796 Phillips, W.M., Sloan, V.F., Shroder, J.F. Jr, Sharma, P., Clarke, M.L., Rendell, H.M., 2000.

1797 Asynchronous glaciation at Nanga Parbat, northwestern Himalaya Mountains, Pakistan. Geology $1798 \quad 28,431-434$.

1799

1800 Porter, S.C., 1970. Quaternary glacial record in the Swat Kohistan, West Pakistan. Geological 1801 Society of America Bulletin 81, 1421-1446.

1802

1803 Porter, S.C., 2000. Onset of neoglaciation in the Southern Hemisphere. Journal of Quaternary

1804 Science 15, 395-408.

1805

1806 Porter, S.C., Denton, G.H., 1967. Chronology of neoglaciation in the North American cordillera. 1807 American Journal of Science 265, 177-210.

1808

1809 Pratt-Sitaula, B., 2005. Glaciers, climate, and topography in the Nepalese Himalaya. PhD Thesis, 1810 University of California, Santa Barbara.

1811

1812 Pratt-Sitaula, B., Burbank, D.W., Heimsath, A.M., Humphrey, N.F., Oskin, M., Putkonen, J., 1813 2011. Topographic control of asynchronous glacial advances: a case study from Annapurna, 1814 Nepal. Geophysical Research Letters, 38, L245092, doi:10.1029/2011GL049940.

1815

1816 Prell, W. L. Kutzbach, J. F. 1992. Sensitivity of the Indian monsoon to forcing parameters and 1817 implications for its evolution. Nature 360, 647-652.

1818 
1819 Pu, Q., 1991. Quaternary glaciers in China. In: Zhang, Z., Shao, S., Tong, G., Cao, J. (Eds.), The 1820 Quaternary of China. China Ocean Press, Beijing, 240-273 pp.

1821

1822 Putkonen, J., Swanson, T., 2003. Accuracy of cosmogenic ages for moraines. Quaternary

1823 Research 59, 255-261.

1824

1825 Putkonen, J., O’Neal, M.A., 2006. Degradation of unconsolidated Quaternary landforms in the 1826 western North America. Geomorphology 75, 408-419.

1827

1828 Putkonen, J., Connolly, J., Orloff, T., 2008. Landscape evolution degrades the geologic signature 1829 of past glaciations. Geomorphology 97, 208-217.

1830

1831 Putnam, A., Schaefer, J.M., Barrell, D.J.A., vandergoes, M., denton, G.H., Kaplan, M.R., Finkel,

1832 R.C., Schwartz, R., Goehring, B.M., Kelley, S.E., 2010. In situ cosmogenic 10Beproduction-rate

1833 calibration from the Southern Alps, New Zealand. Quaternary Geochronology 5, 392-409.

1834

1835 Reimer, P.J., Baillie, M.G.L., Bard, E., Bayliss, A., Beck, J.W., Bertrand, C.J.H., Blackwell, P.G., 1836 Buck, C.E., Burr, G.S., Cutler, K.B., Damon, P.E., Edwards, R.L., Fairbanks, R.G., Friedrich, M., 1837 Guilderson, T.P., Hogg, A.G., Hughen, K.A., Kromer, B., McCormac, G., Manning, S., Ramsey, 1838 C.B. Reimer, R.W., Remmele, S., Southon, J.R. Stuiver, M., Talamo, S., Taylor, F.W., van der

1839 Plicht, J., Weyhenmeyer, C.E. 2004. INTCAL04 terrestrial radiocarbon age calibration, 0-26 Cal 1840 Kyr BP. Radiocarbon 46, 1029-1058.

1841

1842 Ren, J., Qin, D., Kang, S., Hou, S., Pu, J., Jing, Z., 2004. Glacier variations and climate warming 1843 and drying in the central Himalayas. Chinese Science Bulletin, 49, 65-69. 
1845 Richards, B.W.M., 1999. Paleoclimate of South Asia over the last 80 ka: luminescence ages of 1846 sediment from former glaciations in Nepal and Pakistan. Unpublished PhD thesis, Royal

1847 Holloway, University of London, UK.

1848

1849 Richards, B.W.M., 2000. Luminescence dating of Quaternary sediments in the Himalaya and

1850 High Asia: a practical guide to its use and limitations for constraining the timing of glaciation.

1851 Quaternary International 65/66, 49-61.

1852

1853 Richards, B.W.M., Owen, L.A., Rhodes, E.J., 2000a. Timing of Late Quaternary glaciations in 1854 the Himalayas of northern Pakistan. Journal of Quaternary Science 15, 283-297.

1855

1856 Richards, B.W.M., Benn, D., Owen, L.A., Rhodes, E.J., Spencer, J.Q., 2000b. Timing of Late

1857 Quaternary glaciations south of Mount Everest in the Khumbu Himal, Nepal. Geological Society 1858 of America Bulletin 112, 1621-1632.

1859

1860 Röhringer, I., Zech, R., Abramowski, U., Sosin, P., Aldahan, A., Kubik, P.W., Zoller, L., Zech, 1861 W., 2012. The late Pleistocene glaciation in the Bogchigir Valleys (Pamir, Tajikistan) based on

$1862{ }^{10}$ Be surface exposure dating. Quaternary Research 78, 590-597.

1863

1864 Röthlisberger, F., Geyh, M.A., 1985a. Gletscherschwankungen der letzten 10.000 Jahre - Ein

1865 Verleich zwischen Nord- und Südhemisphare (Alpen, Himalaya, Alaska, Südamerika,

1866 Neuseeland). Verlag Sauerländer, Aarau.

1867

1868 Röthlisberger, F., Geyh, M., 1985b. Glacier Variations in Himalayas and Karakoram. Zeitschrift 1869 für Gletscherkunde und Glazialgeologie 21, 237-249.

1870 
1871 Rose, J., Menzies, J., 1995. Glacial stratigraphy, in Menzies, J., ed., Past glacial environments:

1872 Sediments, forms and techniques: Oxford, Butterworth Heinemann, p. 253-284.

1873

1874 Ruddiman, W. F., Kutzbach, J. E., 1991. Plateau uplift and climate change. Scientific American 1875 264, 42-51.

1876

1877 Rupper, S., Roe, G., Gillespie, A., 2008. Spatial patterns of Holocene glacier advance and retreat 1878 in central Asia. Quaternary Research, in press.

1879

1880 Rutter, N.W., 1995. Problematic Ice Sheets. Quaternary International 28, 19-37.

1881

1882 Schäfer, J.M., Tschudi, S., Zhao, Z.,Wu, X., Ivy-Ochs, S., Wieler, R., Baur, H., Kubik, P.W.,

1883 Schluchter, C., 2002. The limited influence of glaciations in Tibet on global climate over the past

1884170000 yr. Earth and Planetary Science Letters 194, 287-297.

1885

1886 Schäfer, J.M., 2000. Reconstruction of landscape evolution and continental paleoglaciations using

1887 in-situ cosmogenic nuclides: Examples from Antarctica and the Tibetan Plateau. Diss. ETH

1888 Zürich, Der Andere Verlag, Osnabrück.

1889

1890 Schaefer, J.M., Oberholzer, P., Zhao, Z.Z., Ivy-Ochs, S., Wieler, R., Baur, H., Kubik, P.W.,

1891 Schluchter, C., 2008. Cosmogenic beryllium-10 and neon-21 dating of late Pleistocene

1892 glaciations in Nyalam, monsoonal Himalayas. Quaternary Science Reviews 27, 295-311.

1893

1894 Scherler, D., Bookhagen, B., Strecker, M.R., von Blanckenburg, F., Rood, D., 2010. Timing and

1895 extent of late Quaternary glaciation in the western Himalaya constrained by ${ }^{10} \mathrm{Be}$ moraine dating

1896 in Garhwal, India. Quaternary Science Reviews 29, 815-831. 
1898 Searle, M.P., Richard, J.P., 2007. Relationships between right-lateral shear along the Karakoram

1899 fault and metamorphism, magmatism, exhumation and uplift: Evidence from the K2-

1900 Gasherbrum, Pangong Ranges, north Pakistan and Ladakh. Journal of the Geological Society, 1901 London, 164, 439-450.

1902

1903 Seong, Y.B., Owen, L.A., Bishop, M.P., Bush, A., Clendon, P., Copland, P., Finkel, R.C., Kamp, 1904 U., Shroder, J.F., 2007. Quaternary glacial history of the Central Karakoram. Quaternary Science 1905 Reviews 26, 3384-3405.

1906

1907 Seong, Y.B., Owen, L.A., Bishop, M.P., Bush, A., Clendon, P., Copland, P., Finkel, R.C., Kamp, 1908 U., Shroder, J.F., 2008. Reply to comments by Matthias Kuhle on Seong, Y.B., Owen, L.A., 1909 Bishop, M.P., Bush, A., Clendon, P., Copland, P., Finkel, R.C., Kamp, U., Shroder, J.F., 2007.

1910 Quaternary Glacial History of the Central Karakoram. Quaternary Science Reviews 27, 165619111658.

1912

1913 Seong, Y.B., Owen, L.A., Yi, C., Finkel, R.C., 2009a. Quaternary glaciation of Muztag Ata and 1914 Kongur Shan: evidence for glacier response to rapid climate changes throughout the Late Glacial 1915 and Holocene in westernmost Tibet. Geological Society of America, Bulletin 121, 348-365.

1916

1917 Seong, Y.B., Bishop, M.P., Bush, A., Clendon, P., Copland, P., Finkel,. R., Kamp, U., Owen, 1918 L.A., Shroder, J.F., 2009b. Landforms and landscape evolution in the Skardu, Shigar and Braldu 1919 Valleys, Central Karakoram. Geomorphology 103, 251-267.

1920 
1921 Seong, Y.B., Owen, L.A., Yi, C., Finkel. R.C., Schoenbohm, L., 2009c. Geomorphology of 1922 anomalously high glaciated mountains at the northwestern end of Tibet: Muztag Ata and Kongur 1923 Shan. Geomorphology 103, 227-250.

1924

1925 Seong, Y.B., Owen, L.A., Caffee, M.W., Kamp, U., Bishop, M.P., Bush, A., Copland, L. Shroder, 1926 J.F. 2009d Rates of basin-wide rockwall retreat in the K2 region of the Central Karakoram 1927 defined by terrestrial cosmogenic nuclide ${ }^{10} \mathrm{Be}$. Geomorphology 107, 254-262.

1928

1929 Sharma, M.C., Owen, L.A., 1996. Quaternary glacial history of NW Garhwal Himalayas.

1930 Quaternary Science Reviews 15, 335-365.

1931

1932 Shi, Y., Ren, B., Wang, J., Derbyshire, E., 1986. Quaternary Glaciation in China. Quaternary 1933 Science Reviews 5, 503-510.

1934

1935 Shi, Y., Zheng, B., Li, S., 1992. Last glaciation and maximum glaciation in the Qinghai-Xizang 1936 (Tibet) Plateau: A controversy to M.Kuhle's ice sheet hypothesis. Zeitschrift für Geomorphologie $193784,19-35$.

1938

1939 Shi, Y. Lui, S., 2000. Estimation on the response of glaciers in China to global warming in the $194021^{\text {st }}$ century. Chinese Science Bulletin, 45, 668-672.

1941

1942 Shi, Y., 1992. Glaciers and glacial geomorphology in China. Zeitschrift für Geomorphologie 86, 1943 19-35.

1944 
1945 Shiraiwa, T., Watanabe, T., 1991. Late Quaternary glacial fluctuations in the Langtang Valley, 1946 Nepal Himalaya, reconstructed by relative dating methods. Arctic and Alpine Research 23, 4041947416.

1948

1949 Shroder, J., Owen, L.A., Seong, Y.B.*, Bishop, M.P., Bush, B., Caffee, M.W., Finkel, R.C.,

1950 Kamp, U., 2011. The role of mass movement on landscape evolution in the Central Karakoram:

1951 Discussion and speculation. Quaternary International 236, 34-47.

1952

1953 Spencer, J.Q., Owen, LA., 2004. Optically stimulated luminescence dating of Late Quaternary

1954 glaciogenic sediments in the upper Hunza valley: validating the timing of glaciation and assessing

1955 dating methods. Quaternary Sciences Reviews 23, 175-191.

1956

1957 Strasky, S., Graf, A.A., Zhao, Z.Z., Kubik, P.W., Baur, H., Schluchter, C., Wieler, R., 2009. Late

1958 glacial ice advances in southeast Tibet. Journal of Asian Earth Science 34, 458-465.

1959

1960 Stone, J.O., 2000. Air pressure and cosmogenic isotope production. Journal of Geophysical

1961 Research 105, 23753-23759.

1962

1963 Su, Z., Shi, Y., 2002. Response of monsoonal temperate glaciers to global warming since the

1964 Little Ice Age. Quaternary International 97-98, 123-132.

1965

1966 Su, Z., Shi, Y., Zheng, B., 2002. Quaternary glacial remains on the Gongga Mountain and the 1967 division of glacial period. Advance in Earth Sciences 17, 647-2002.

1968

1969 Taylor, P.J., Mitchell, W.A., 2000. Late Quaternary glacial history of the Zanskar Range, North1970 west Indian Himalaya. Quaternary International 65/66, 81-100. 
1972 Thompson, L.G., 2000. Ice core evidence for climate change in the Tropics: Implications for our 1973 future. Quaternary Science Reviews 19, 19-35.

1974

1975 Thompson, L.G., Mosley-Thompson, E., Davis, M.E., Bolzan, J.F., Dai, J., Yao, T., Gundestrup, 1976 N., Wu, X., Klein, L., Xie, Z., 1989. Holocene-Late Pleistocene climatic ice core records from 1977 Qinghai-Tibetan Plateau. Science 246, 474-477.

1978

1979 Thompson, L.G., Yao, T., Davis, M.E., Henderson, K.A., Mosley-Thompson, E., Lin, P.-N., 1980 Beer, J., Synal, H.A., Cole-Dai, J., Bolzan, J.F., 1997. Tropical climate instability: the Last 1981 Glacial Cycle from a Qinghai-Tibetan ice core. Science 276, 1821-1825.

1982

1983 Thompson, L.G., Yao, T., Mosley-Thompson, E., Davis, M.E., Henderson, K.A., Lin, P-N., 2000.

1984 A high-resolution millennial record of the South Asian monsoon from Himalayan ice cores.

1985 Science 289, 1916-1919.

1986

1987 Trinkler, E., 1930. The Ice-Age on the Tibetan Plateau and in the adjacent region. Geography 1988 Journal 75, 225-232.

1989

1990 Tschudi, S., Schäfer, J.M., Zhao, Z.Z., Wu, X.H., Ivy-Ochs, S., Kubik, P.W., Schlu $\square$ chter, C., 1991 2003. Glacial advances in Tibet during the Younger Dryas? Evidence from cosmogenic ${ }^{10} \mathrm{Be}$, $1992{ }^{26} \mathrm{Al}$, and ${ }^{21} \mathrm{Ne}$. Journal of Asian Earth Science 22, 301-306.

1993

1994 Tsukamoto, S., Asahi, K., Watanabe, T., Kondo, R., Rink, W.J., 2002. Timing of past glaciation 1995 in Kanchenjunga Himal, Nepal by optically stimulated luminescence dating of tills. Quaternary 1996 International 97/98, 57-68. 
1998 Wang, F., Fan, C.Y., 1987. Climatic changes in the Qinghai-Xizang (Tibetan) region of China 1999 during the Holocene. Quaternary Research 28, 50-60.

2000

2001 Wang, J., Raisbeck, G., Xu, X.B., Yiou, F., Bai, S.B., 2006. In situ cosmogenic ${ }^{10}$ Be dating of the 2002 Quaternary glaciations in the southern Shaluli Mountain on the southeastern Tibetan Plateau.

2003 Science in China Series D: Earth Sciences 49, 1291-1298.

2004

2005 Wang, J., Kassab, C., Harbor, J.M., Caffee, M.W., Cui, H., Zhang, G., 2013. Cosmogenic nuclide constraints 2006 on late Quaternary glacial chronology on the Dalijia Shan, northeastern Tibetan Plateau. Quaternary 2007 Research 79, 439-451.

2008

2009 Waragai, T. 2005. Holocene calcrete crust deposits on the moraine of Batura Glacier, northern 2010 Pakistan. The Island Arc 14, 368-377.

2011

2012 Waragai, T., 1998. Effects of rock surface temperature on exfoliation, rock varnish, and lichens 2013 on a boulder in the Hunza Valley, Karakoram Mountains, Pakistan. Arctic and Alpine Research $2014 \quad 30,184-192$.

2015

2016 Watanabe, T., Shiraiwa, T., Ono, Y. 1989. Distribution of periglacial landforms in the Langtang 2017 Valley, Nepal Himalaya. Bulletin of Glacier Research 7, 209-220.

2018

2019 Willett, S.D., 2010. Erosion on a line. Tectonophysics 484, 168-180.

2020

2021 Williams, Van S., 1983, Present and former equilibrium-line altitudes near Mount Everest, Nepal 
2022 and Tibet: Arctic and Alpine Research, v. 15, p. 201-211.

2023

2024 Wu, G.H., 1984a. The preliminary observation of Neoglacial in the Qilian Mountains. (In

2025 Chinese with English summary). Journal of Glaciology and Geocryology 6, 53-60.

2026

2027 Wu, G.H., 1984b. The Quaternary glaciation questions in Qilian mountains. In: Memoirs of 2028 Lanzhou Institute of Glaciology and Geocryology, Chinese Academy of Science (No. 5): Glacier

2029 Changes and Utilizations in Qilian Mountains. Lanzhou Institute of Glaciology and Geocryology, 2030 Chinese Academy of Science. Science Press, Beijing, 116-123.

2031

2032 Wu, Y., Cui, Z., Liu, G., Ge, D., Yin, J., Xu, Q., Pang, Q. 2001. Quaternary geomorphological 2033 evolution of the Kunlun Pass area and uplift of the Qinghai-Xizang (Tibet) Plateau.

2034 Geomorphology 36, 203-216.

2035

2036 Von Wissmann H., 1959. Die heutige Vergletscherung und Schneegrenze in Hochasien mit 2037 Hinweisen auf die Vergletscherung der letzten Eiszeit. Akademie der Wissenschaften und der 2038 Literatur in Mainz, Abhandlungen der Mathematisch-Naturwissenschaftlichen Klasse 14, 1212039123.

2040

2041 Yao, T., Shi, Y., Thompson, L.G., 1997. High resolution record of paleoclimate since the Little 2042 Ice Age from the Tibetan ice cores. Quaternary International 37, 19-23.

2043

2044 Yao, T., Thompson, L.G., Mosley-Thompson, E., Yang, Z., Zhang, X., Lin, P., 1996.

2045 Climatological significance of $\delta^{18} \mathrm{O}$ in north Tibetan ice cores. Journal of Geophysical Research 2046 101, D23, 29,531-29,537. 
2048 Yang, B., Brauning, A., Dong, Z., Zhang, Z., Keqing, J. 2008. Late Holocene monsoonal

2049 temperate glacier fluctuations on the Tibetan Plateau. Global and Planetary Change, 60, 126-140.

2050

2051 Yang, J.Q., Zhang, W., Cui, Z.J., Yi, C.L., Liu, K.X., Ju, Y.J., 2006. Late Pleistocene glaciation

2052 of Diancang Mountains and Gongwang Mountains, southeastern margin of the Tibetan Plateau.

2053 Quaternary International 154-155, 52-62.

2054

2055 Yi, C., Owen, L.A., 2006. Quaternary palaeoenvironmental change in Tibet and the bordering

2056 mountains. Quaternary International 154/155, 157 pp.

2057

2058 Yi, C., Li, X., Qu, J., 2002. Quaternary glaciation of Puruogangri-the largest modern ice field in 2059 Tibet. Quaternary International 97/98, 111-123.

2060

2061 Yi, C., Liu, K.X., Cui, Z.J., Jiao, K.Q., Yao, T.D., He, Y.Q., 2004. AMS radiocarbon dating of

2062 late Quaternary glacial landforms, the source area of the Urumqi River, Tien Shan: a pilot study

2063 of ${ }^{14} \mathrm{C}$ dating on inorganic carbon. Quaternary International 121, 99-107.

2064

2065 Yi, C., Chen, H., Yang, J., Liu, B., Fu, P., Liu, K., Li, S., 2008. Review of Holocene glacial

2066 chronologies based on radiocarbon dating in Tibet and its surrounding mountains. Journal of

2067 Quaternary Science 23, 533-558.

2068

2069 Yin, A, Harrison, T.M., 2000. Geologic evolution of the Himalayan-Tibetan orogen. Annual

2070 Reviews of Earth and Planetary Sciences 28, 211-80.

2071

2072 Zech, R., 2012a. A Late Pleistocene glacial chronology from the Kitschi-Kurumdu Valley, Tien

2073 Shan (Kyrgyzstan), based on 10Be surface exposure dating. Quaternary Research 77, 281-288. 
2075 Zech, R., Abramowski, U., Glaser, B., Sosin, P., Kubik, P.W., Zech, W., 2005. Late Quaternary

2076 glacier and climate history of the Pamir Mountains derived from cosmogenic ${ }^{10} \mathrm{Be}$ exposure ages.

2077 Quaternary Research 64, 212-220.

2078

2079 Zech, W., Glaser, B., Abramowski, U., Dittmar, C., Kubik, P.W., 2003. Reconstruction of the

2080 Late Quaternary Glaciation of the Macha Khola valley (Gorkha Himal, Nepal) using relative and

2081 absolute $\left({ }^{14} \mathrm{C},{ }^{10} \mathrm{Be}\right.$, dendrochronology) dating techniques. Quaternary Science Reviews 22, 2253-

20822265.

2083

2084 Zech, W., Glaser, B., Ni, A., Petrov, M., Lemzin, I., 2000. Soil as indicators of the Pleistocene

2085 and Holocene landscape history: Alay Range (Khyrgstan). Quaternary International 65/66: 161-

2086170.

2087

2088 Zech, W., Glaser, B., Sosin, P., Kubik, P.W., Zech, W., 2003. Evidence for long-lasting landform

2089 surface instability on hummocky moraines in the Pamir Mountains (Tajikistan) from ${ }^{10} \mathrm{Be}$ surface 2090 exposure dating. Earth and Planetary Science Letters 237, 453-461.

2091

2092 Zech, R., Zech, M., Kubik, P.W., Kharki, K., Zech, W., 2009. Deglaciation and landscape history 2093 around Annapurna, Nepal, based on ${ }^{10} \mathrm{Be}$ surface exposure dating. Quaternary Science Reviews $2094 \quad 28,1106-1118$.

2095

2096 Zech, R., Abramowski, U., Glaser, B., Sosin, P., Kubik, P.W., Zech, W., 2005a. Late Quaternary 2097 glacial and climate history of the Pamir Mountains derived from cosmogenic ${ }^{10}$ Be exposure ages. 2098 Quat. Res. 64, 212-220. 
2100 Zech R., Röhringer, I., Sosin, P., Kabgov, H., Merchel, S., Akhmadaliev, S., Zech, W., 2013.

2101 Late Pleistocene glaciations in the Gissar Range, Tajikistan, based on ${ }^{10} \mathrm{Be}$ surface exposure

2102 dating. Palaeogeography, Palaeoclimatology, Palaeoecology 369, 253-261.

2103

2104 Zeitler, P.K., Meltzer, A.S., Koons, P.O., Craw, D., Hallet, B., Chamberlain, C.P., Kidd, W.S.F.,

2105 Park, S.K., Seeber, L., Bishop, M., Shroder, J.F., 2001. Erosion, Himalayan geodynamics and the 2106 geomorphology of metamorphism. GSA Today 11, 4-8.

2107

2108 Zhang, Z.S., 1988. Fluctuation of glaciers on the northwest slope of Mt. Nanjagbarwa since the

2109 last glaciation. (Chinese with English summary). Journal of Glaciology and Geocryology 10,

$2110 \quad 180-188$.

2111

2112 Zheng, B., 1997. Glacier variation in the monsoon maritime glacial region since the last

2113 glaciation on the Qinghai-Xizang (Tibetan) plateau. In: The Changing Face of East Asia During

2114 the Tertiary and Quaternary. Center of Asian Studies, The University of Hong Kong, 103-112.

2115

2116 Zheng, B.X., 2006. Quaternary glaciations in Nyainqentanglha Mountains. In: Shi, Y.F., Su, Z.,

2117 Cui, Z.J. (Eds.), The Quaternary Glaciations and Environmental Variations in China. Science and

2118 Technology Press of Hebei Province, Shijiazhuang, 374-400.

2119

2120 Zheng, B.X., Ma, Q.H., 1994. The glacier variation, climatic change and the river valley

2121 development in the Holocene on the Gongga Mountains. (Chinese with English summary). Acta

2122 Geographica Sinica 49, 500-508.

2123

2124 Zheng, B.X., Li, J.J., 1986. Regional divisions of existing glaciers in Xizang region. In: Li, J.J.,

2125 Zheng, B.X., Yang, X.J. (Eds.), Glaciers of Xizang (Tibet). Science Press, Beijing, 130-148. 
2127 Zheng, B., Rutter, N., 1998. On the problem of Quaternary glaciations, and the extent and

2128 patterns of Pleistocene ice cover in the Qinghai-Xizang (Tibet) plateau. Quaternary International $212945 / 46,109-122$.

2130

2131 Zheng, B.X., Li, S.J., Wang, S.M., 1995. The Quaternary glacier evolution history in the

2132 surrounding high mountains, Zoige Basin. In: Expert Committee on Qingzang Program (Eds.),

2133 The Formation Evolution, Environmental Variance, and Ecosystem Research in Qinghai-Tibet

2134 Plateau, Science Press, Beijing, 218-226.

2135

2136 Zhao, J., Liu, S., He, Y., Song, Y., 2009. Quaternary glacial chronology of the Ateaoyinake River

2137 Valley, Tianshan Mountains, China. Geomorphology 103, 276-284.

2138

2139 Zhao, J., Lai, Z., Liu, S., Song, Y., Li, Z., Yin, X., 2012. OSL and ESR dating of glacial deposits

2140 and its implications for glacial landform evolution in the Bogeda Peak area, Tianshan range,

2141 China. Quaternary Geochronology, 10, 237-243.

2142 Zhou, S., Li, J., Zhao, J., Wang, J., Zheng, J. 2011. Quaternary glaciations: extent and chronology

2143 in China. In: Elhers, J., Gibbard, P. and Hughes, P.D. (Eds.), Quaternary Glaciations - Extent and

2144 Chronology: a closer look. Developments in Quaternary Science, volume 15, Elsevier,

2145 Amsterdam, $2^{\text {nd }}$ Edition, 981-1002.

2146

2147 Zhou, S.Z., Chen, F.H., Pan, B.T., Cao, J.J. Li, J., Derbyshire, E., 1991. Environmental change

2148 during the Holocene in western China on a millennial timescale. Holocene 1, 151-156.

2149

2150 Zhou, S.Z., Xu, L.B., Colgan, P.M., Mickelson, D.M., Wang, X.L., Wang, J., Zhong, W., 2007. 
2151 Cosmogenic ${ }^{10} \mathrm{Be}$ dating of Guxiang andBaiyu glaciations. Chinese Science Bulletin 52, 138721521393.

2153

2154 Zhou, S.Z., Yi, C.L., Shi, Y.F., Ye, Y.G., 2001. Study on the ice age MIS 12 in Western China. 2155 Journal of Geomechanics 7 (4), 321-327 (in Chinese with English Abstract).

2156

2157 Zhou, S.Z., Wang, X.L., Wang, J., Xu, L.B., 2006. A preliminary study on timing of the oldest

2158 Pleistocene glaciation in Qinghai-Tibetan Plateau. Quaternary International 154/155, 44-51

2159

2160 Zhou, S.Z., Wang, J., Xu, L.B., Wang, X.L., Colgan, P.M., Mickelson, D.M., 2010. Glacial

2161 advances in southeastern Tibet during late Quaternary and their implications for climatic changes.

2162 Quaternary International 218, 58-66.

2163 


\section{FIGURES}

2165 Fig. 1. Digital elevation model produced using GeoMapApp

2166 (http://www.geomapapp.org) showing the area discussed in this paper.

2168 Fig. 2. Simplified views of characteristic summer (A) and winter (B) air circulation over 2169 southern and central Asia. The Tibetan Plateau and bordering mountains above $5000 \mathrm{~m}$ 2170 asl are shown within the areas shaded brown. The blue solid lines in (A) and (B) indicate

2171 airflow at about 6000 and $3000 \mathrm{~m}$ asl, respectively, and the dark blue dashed lines airflow 2172 at about $600 \mathrm{~m}$ asl (adapted from Owen et al. 1998 and Benn \& Owen 1998).

2174 Fig. 3. Precipitation maps with the TRMM data draped over the DEM with 36\% opacity. 2175 Units are in mm/a and are averaged over 12 years (1998-2009). From data product 2B31, 2176 a combined Precipitation Radar (PR) / TRMM Microwave Imager (TMI) rain-rate 2177 product with path-integrated attenuation at $4 \mathrm{~km}$ horizontal and $250 \mathrm{~m}$ vertical resolutions 2178 (http://www.geog.ucsb.edu/ bodo/TRMM/\#ascii). The inset map (from Owen et al., 21792005 ) shows a larger area to compensate for the regions not covered by TRMM data. 2180

2181 Fig. 4. Glaciers of the Himalayan-Tibetan orogen. A and B) Small valley polar-type 2182 continental glaciers in the Zanskar Range of northern Inida. C) Rongbuk glacier in Tibet 2183 and its end moraine on the northern slopes of Mt. Everest. D) Ghulkin glacier in the 2184 Karakoram Mountains of Northern Pakistan showing an impressive laterofrontal moraine 2185 complex in the fore and middle ground and the accumulation area in the top right of the 2186 photograph. E) Maritime-type monsoonal influenced unnamed glacier in the Bhagarathi 
2187 valley in the Garhwal Himalaya of Northern India. The contemporary laterofrontal

2188 moraines and outlet glaciofluvial stream is inset into an older lateronfrontal moraine

2189 complex. F) Morainic rock glacier in the Milang Valley in Lahul Himalaya of Northern

2190 India. The very last remnants of glacial ice can be seen in the top left part of the

2191 photograph.

2192

2193 Fig. 5. Selected reconstructions for the maximum extent of glaciation during the Last

2194 Glacial across Tibet and the bordering mountains (from Owen et al. 2008a, and Owen,

2195 2010). Light grey, relief over $4000 \mathrm{~m}$ above sea level; dark grey, areas considered

2196 glaciated. A) Klute's (1930) reconstruction based on a temperature depression of $\sim 4^{\circ} \mathrm{C}$,

2197 with a shift of climatic zones to the south and an intensification of atmospheric

2198 circulation such that precipitation increased towards the dry areas of central Asia. B)

2199 Frenzel's (1960) reconstruction based on the detailed work of von Wissmann (1959),

2200 who evaluated the observations of the earliest explorers. C) Kuhle's (1985)

2201 reconstruction based on field observations and extrapolation of large equilibrium-line

2202 altitude depressions (>1000 $\mathrm{m}$ ) from the margins of Tibet into the interior regions. D)

2203 Reconstruction of Shi (1992) and Li et al. (1991) based on detailed field mapping of

2204 glacial and associated landforms and sediments.

2205

2206 Fig. 6. Examples of large runout landslides in the Himalaya and Karakoram. A) The

2207 Ghoro Cho rock avalanche in the Shigar valley, Karakoram, Northern Pakistan, dated by

2208 radiocarbon to $\sim 7.1$ ka by Hewitt (1999) and by ${ }^{36} \mathrm{Cl}$ to Late Glacial through early

2209 Holocene by Shroder et al. (2011). B) Katzarah landslides in the Indus valley of the 
2210 Karakoram, Northern Pakistan mapped and studied by Hewitt (1999) and dated by Hewitt 2211 et al. (2011) to 7.8 ka using ${ }^{10} \mathrm{Be}$. C) The Kelang Serai landslide in the Lahul Himalaya

2212 dated by ${ }^{10} \mathrm{Be}$ to $6.6 \pm 0.4$ ka by Dortch et al. (2009). D) The Hattian Bala landslide

2213 triggered by the 2005 Kashmir earthquake. The landslide buried four villages resulting in

$2214 \sim 450$ fatalities (described in Dunning et al., 2007 and Owen et al., 2008b).

2215

2216 Fig. 7. Geomorphology of the Skardu Basin, Karakoram Mountains, Northern Pakistan

2217 (after Owen et al., 1988). Hewitt $(1998,1999,2011)$ argues that some of the mapped

2218 moraines are long runout landslides; these are highlighted by the golden ellipses

2219 numbered I-VIII (adapted from Kamp and Owen, 2011).

2220

2221 Fig. 8. Examples of geomorphic maps produced by Owen et al. (2012) for developing a

2222 morphostratigraphy in the Tashkurgan valley of the Chinese Pamir. A) through D) are

2223 individual study areas within the valley. The legends are separated into feature types in

2224 different panels, but refer to all panels. The large white text on each moraine is the

2225 relative assignment of glacial ages to the landforms. The letters K, J, HD and T refer to

2226 the study areas (e.g. $\mathrm{K}=$ Kuzigun study area) and the numbers refer to the relative ages (1

2227 being the oldest age glacial landform in the particular study area). Sampling points for

$2228{ }^{10} \mathrm{Be}$ TCN dating are shown to help illustrate a typical strategy for dating. The ${ }^{10} \mathrm{Be}$ ages

2229 for these samples are shown in Figure 10.

2230

2231 Fig. 9. A) Röthlisberger and Geyh's (1985b) summary of glacier fluctuations in the

2232 Himalaya and Karakoram defined by radiocarbon dating. The original curves of 
2233 Röthlisberger and Geyh (1985b) were plotted on a radiocarbon timescale, but this figure

2234 redrafted by Owen (2009) has the broad advances and retreats plotted for calibrated years

2235 using Reimer et al.'s timescale (2004). B) Probability distribution frequency plot and

2236 scatter graph for radiocarbon ages from the Himalaya-Tibetan orogen. Only minimum

2237 radiocarbon ages, that is, ones that are younger than the moraines they are dating are

2238 plotted on the probability distribution graph (see Table 2 for data and sources). Light

2239 gray bands indicate times of rapid climate changes after Mayewski et al. (2004).

2240

2241 Fig. 10. Log-normal plots of > $1700 \mathrm{TCN}$ ages from the Tibetan-Himalayan orogen

2242 expressed as percentage difference from the Lal (1991) - Stone (2000) time-independent

2243 scaling scheme. A) Published ages, light gray shading shows ages with differences that

2244 would fit within geomagnetic corrections schemes. Dark gray area delineates ages that fit

2245 in the Lal (1991) - Stone (2000) time dependent scheme specifically, which covers the

2246 majority of geomagnetic corrected ages. B) scaling schemes including geomagnetic

2247 correction, C) time-independent ages using new regional production rates, and D) Balco

2248 et al. (2009) regional production rate combined with scaling schemes including

2249 geomagnetic corrections. Thick horizontal dashed lines enclose $10 \%$ deviation from time-

2250 independent ages. All primary data are presented in Appendix 1.

2251

2252 Fig. 11. Log-normal plot of 267 gaussians that represent regional glacial stages

2253 (combined local glacial stages) for the semi-arid western end and the monsoon-

2254 influenced areas of the Himalayan-Tibetan orogen of Dortch et al. (2013) and Murari et

2255 al. (2013), respectively. Y-axis position is determined by the total number of samples 
2256 from a landform(s). Black dots indicate gaussians that enclose 3 or more ages. Green

2257 dots represent gaussians that enclose two ages and are considered tentative. Red dots

2258 represent either the oldest gaussian from a dataset that was too scattered to fit a normal

2259 distribution or landforms with a single age. The 31 gaussians from landforms that do not

2260 follow morphostratigraphic order are excluded from this plot.

2261

2262 Fig. 12. An example of the spread of ${ }^{10} \mathrm{Be}$ ages for glacial boulders dated to define glacial 2263 stages from Owen et al. (2012) for the Tashkurgan valley in the Pamir. The glacial stages 2264 are plotted by relative age (oldest to the left). The horizontal black lines and the dark grey 2265 bands show the mean and 1s for each glacial stage, respectively. The light blue bands 2266 highlight interstadials and interglacials based on the Marine Oxygen Isotope Stages 2267 (MIS) of Martinson et al. (1987). Note how the spread of ages for each glacial stage 2268 becomes progressively larger with relative age, likely reflecting geologic effects such as 2269 weathering, exhumation and toppling of boulders resulting in anomalously young ages. 2270

2271 Fig. 13. Sampling strategies for OSL and TCN dating of moraines and associated 2272 deposits and landforms proposed by Benn and Owen (2002) showing the significance of 2273 each dating site.

2275 Fig. 14. View of section through a composite latero-frontal moraine at Lhotse-Nup in the 2276 Khumbu Himal, Nepal. Measured drawing after Richards et al. (2000b). UC1, UC2, and 2277 UC3 represent three unconformities. OSL dating undertaken by Richards et al. (2000b) is 2278 shown to illustrate the long and complex history of this landform. The lithofacies codes 
2279 of Eyles et al. (1983) are used to describe the sedimentology (Dmm - massive matrix-

2280 supported diamict; Dms — stratified, matrix-supported diamict; Dcs—stratified, clast-

2281 supported diamict; Sh—low-angle, cross-stratified, very fine to very coarse sands; Gh-

2282 horizontally bedded gravels).

2283

2284 Fig. 15. Glacial chronology for Mount Everest after Finkel et al. (2003) and Owen et al.

2285 (2009). A) Schematic diagram showing the stratigraphic context and locations, and

2286 graphic sedimentary logs for samples for OSL (in red samples OSL-1 to OSL-22) and

$2287{ }^{10} \mathrm{Be}$ (in black Ron 1 to 78 ) for the Rongbuk valley on the northern side of Mount Everest

2288 (after Owen et al., 2009). The ages for these samples are shown in part B. B) ${ }^{10} \mathrm{Be}$ and

2289 OSL ages for moraines for the Rongbuk valley. Ages for each dated moraine are enclosed

2290 by a different color rectangle. The proximal outwash terrace is also dated (after Owen et

2291 al., 2009). C) Probability distribution plots for ${ }^{10} \mathrm{Be}$ ages for glacial stages on either side

2292 of Mount Everest (upper plots = Rongbuk valley and lower plots $=$ Khumbu Himal on the

2293 south side of Mt. Everest) are compared (after Owen et al., 2009).

2294

2295 Fig. 16. Examples of evidence for very old glaciation in the Himalayan-Tibetan orogen.

2296 A) View looking east along the Indus Valley from a Leh glacial stage moraine

2297 (penultimate or older glacial cycle) towards Indus glacial stage moraines in the middle

2298 distance that date to more 430 ka (Owen et al., 2006a). B) Naimona'nyi glacial stage

2299 moraine dating to MIS 10 or older in the foreland of the Ronggua Gorger on the west side

2300 of Gurla Mandata. This particular boulder was dated using ${ }^{10} \mathrm{Be} \mathrm{TCN}$ to $\sim 482 \pm 48 \mathrm{ka}$

2301 (Owen et al., 2010). C) Dabudaer glacial stage moraine near the mouth of the 
2302 Jialongquiete valley in the Tashkurgan valley, which dates to penultimate or an earlier 2303 glacial cycle. This particular boulder was dated to $291 \pm 20 \mathrm{ka}$ using ${ }^{10} \mathrm{Be}$ TCNs (Owen et 2304 al., 2012).

2305

2306 Fig. 17. Probability distribution plots for ${ }^{10} \mathrm{Be}$ TCN moraine boulder ages for the 2307 Himalayan-Tibetan orogen presented for different time slices. All ages were recalculated 2308 using the Lal (1991)-Stone (2000) time dependent model (see Appendix 1 for the data). 2309

2310 Fig. 18. Probability distribution frequency plots for ${ }^{10} \mathrm{Be} \mathrm{TCN}$ moraine boulder ages for 2311 different time slices for four regional subdivisions of the Himalayan-Tibetan orogen 2312 building on the methods of Owen et al. (2008a). Compared to Owen et al. (2008a), the 2313 data set has increased from 777 to $>1700$ ages (see Appendix 1 for data). All ages were 2314 recalculated using the Lal (1991)-Stone (2000) time dependent model. 2315

2316 Fig. 19. Simplified glacial chronologies for each region in the Himalayan-Tibetan orogen 2317 back to $100 \mathrm{ka}$ (adapted from Owen et al., 2012). The color bars represent times of 2318 glacial advances and their duration includes the likely uncertainty in the ages. The color 2319 scheme is used to suggest tentative regional correlations. Marine Oxygen Isotope Stages 2320 are shown to the far right.

2322 Fig. 20. Glacial geologic study areas at the western end of the Himalayan-Tibetan orogen 2323 showing the ages of local last glacial maxima and approximate extent of valley 2324 glaciation. Data from Owen et al. (1992, 2001, 2010, 2002b, 2007, 2002a, 2006a), 
2325 Sharma and Owen (1996), Phillips et al. (2000), Richards et al. (2000a), Taylor and

2326 Mitchell (2000), Barnard et al. (2004a, b), Zech et al. (2005a), Chevalier et al. (2005,

2327 20011), Abramowski et al. (2006), Seong et al. (2009a), Dortch et al. (2010a,2011b,c),

2328 Hedrick et al. (2011), Rohringer et al. (2012) and Lee et al. (in press). The area shown in

2329 the right panel is same area that was modeled by Bishop et al. (2010) using a seventy-

2330 year simulation with a fully coupled atmosphere-ocean general circulation model for the

2331 global LGM, $16 \mathrm{ka}, 9 \mathrm{ka}, 6 \mathrm{ka}$ and a doubling of $\mathrm{CO}_{2}$.

2332

2333 Fig. 21. Age plot of regional glacial stages (semi-arid western Himalaya-Tibetan Stage:

2334 SWHTS) for the semi-arid regions at the western end of the Himalayan-Tibetan orogen

2335 defined by Dortch et al. (2013) and for the monsoon-influences Himalayan-Tibetan

2336 orogen (monsoon Himalayan-Tibetan stages: MOHITS) defined by Murari et al. (2014).

2337 Ages for regional glacial stages are distinct at the 95\% confidence interval despite some

2338 overlap. SWHTS calculations were based on 352 out of $695{ }^{10} \mathrm{Be}$ ages that were

2339 analyzed; 98 failed the cluster analysis, 192 and 50 we excluded for being too young and

2340 too old, respectively. MOHITS calculations were based on 520 out of $1119{ }^{10} \mathrm{Be}$ ages that

2341 were analyzed; 185 failed the cluster analysis, 316 and 98 were excluded for being too

2342 young and too old, respectively. Stacked marine $\delta^{18} \mathrm{O}$ curves of Lisieki and Raymo

2343 (2005), simulated monsoon index and $65^{\circ} \mathrm{N}$ insolation of Leuschner and Sirocko (2003)

2344 and the NGRIP (2004) $\delta^{18} \mathrm{O}$ curve are provided for comparison. The duration of specific

2345 climatic events are marked by red and dark blue bars in the far right column. Light gray

2346 horizontal bands in the far right column indicate times of rapid climate change after

2347 Mayewski et al. (2004). 
2349 Fig. 22. Probability distribution plots for ${ }^{10} \mathrm{Be}$ TCN surface-exposure ages for glacial 2350 advances in Muztag Ata and Kongur Shan in the Chinese Pamir for the last 20 ka (after

2351 Seong et al., 2009a). Moraines of similar advances are grouped with each different color 2352 representing a distinct glacial advance. Light gray bands indicate times of rapid climate 2353 change after Mayewski et al. (2004). The number of boulders dated per each advance is 2354 shown at the bottom of the figure.

2355

2356 


\section{Tables}

2359

\section{Table 1}

2361 Summary of the radiocarbon dating that has been undertaken throughout the Himalayan-

2362 Tibetan orogen for glacial successions.

2363

2364 Table 2

2365 Major optically stimulated luminescence dating projects that has been undertaken for 2366 glacial geologic studies in the Himalayan-Tibetan orogen.

2368 Table 3

2369 Summary of glacial chronologies dated by ${ }^{10} \mathrm{Be}$ methods throughout the Himalayan-

2370 Tibetan orogen listing the dating methods applied to define the ages of glacial advances.

2371

2372 Table 4

2373 Comparison of regional glaciers stages of Dortch et al. (2013) and Murari et al. (2013)

2374 for the semi-arid western end and the monsoonal-influenced areas of the Himalayan-

2375 Tibetan orogen, respectively. Correlations are assessed using student T-Test.

2376

\section{Supplementary Item/Appendix}


2379 Appendix 1. Table listing the Be-10 TCN exposure dating that has been undertaken in the 2380 Himalayan-Tibetan orogen with published ages and recalculated ages using different 2381 scaling models. All references are listed in the main text of the paper. 
Table 1. Summary of major radiocarbon dating studies for the Himalayan-Tibetan orogen.

\begin{tabular}{|c|c|c|c|c|c|c|c|c|c|c|c|c|}
\hline \multirow[t]{2}{*}{ Area } & \multirow[t]{2}{*}{ Location } & \multirow{2}{*}{$\begin{array}{l}\text { Latitude } \\
\left({ }^{\circ} \mathrm{N}\right)\end{array}$} & \multirow{2}{*}{$\begin{array}{l}\text { Longitude } \\
\left({ }^{\circ} \mathrm{E}\right)\end{array}$} & \multirow{2}{*}{$\begin{array}{l}\text { Altitude } \\
\text { (m asl) } \\
\end{array}$} & \multirow{2}{*}{$\begin{array}{l}\text { Dated material } \\
\text { and geomorphic } \\
\text { context }\end{array}$} & \multirow{2}{*}{$\begin{array}{l}\text { Age in relation to } \\
\text { glacial advance }\end{array}$} & \multicolumn{2}{|c|}{ Radiocarbon age (years) } & \multicolumn{3}{|c|}{ Calibrated age (cal years BP) $^{2}$} & \multirow[t]{2}{*}{ Source } \\
\hline & & & & & & & & uncertainty & From & To & $\%$ & \\
\hline \multirow[t]{2}{*}{ Pamir } & $\begin{array}{c}\text { Ayizhisu River, } \\
\text { trib of Wuyitak } \\
\text { River, northern } \\
\text { slope of Kongur } \\
\text { Peak }\end{array}$ & $\sim 38.7^{b}$ & $75.3^{\mathrm{b}}$ & $2700^{b}$ & $\begin{array}{l}\text { Wood root in } \\
\text { terminal } \\
\text { moraines }\end{array}$ & $\begin{array}{l}\text { Younger } \\
\text { Toun }\end{array}$ & 110 & 50 & 277 & 8 & 95.4 & Ono et al. (1997) \\
\hline & & & & & & Younger & 220 & 50 & 431 & -4 & 95.4 & \\
\hline \multirow[t]{7}{*}{ Tien Shan } & $\begin{array}{l}\text { Upper Urumqi } \\
\text { River valley }\end{array}$ & 43.12 & 86.82 & $\sim 4200$ & $\begin{array}{l}\text { Organic carbon } \\
\text { coating on } \\
\text { boulder }\end{array}$ & Younger & 390 & 120 & 652 & -3 & 95.3 & Yi et al. (2004) \\
\hline & & & & & & Younger & 420 & 150 & 676 & -3 & 95.5 & \\
\hline & & & & & $\begin{array}{l}\text { Organic coating } \\
\text { on clast }\end{array}$ & Younger & 1860 & 100 & 2035 & 1545 & 95.4 & \\
\hline & & & & & & Younger & 6560 & 150 & 7700 & 7165 & 95.4 & \\
\hline & & & & & Till matrix & Contemporaneous & 23080 & 510 & 29201 & 26346 & 95.4 & \\
\hline & & & & & & Contemporaneous & 19010 & 450 & 23811 & 21557 & 95.4 & \\
\hline & & & & & & Contemporaneous & 19590 & 130 & 23856 & 22691 & 95.4 & \\
\hline \multirow[t]{6}{*}{ Karakoram } & $\begin{array}{l}\text { Minapin Glacier, } \\
\text { Hunza Valley }\end{array}$ & $\sim 36.25$ & $\sim 74.52$ & $\sim 2000$ & $\begin{array}{l}\text { Wood in } \\
\text { moraines }\end{array}$ & Younger & 325 & 60 & 505 & 158 & 95.4 & Derbyshire et al. (1984) \\
\hline & & & & & & Younger & 685 & 45 & 694 & 553 & 95.4 & \\
\hline & & & & & & Younger & 2265 & 65 & 2453 & 2070 & 95.4 & Liet al. (1986) \\
\hline & $\begin{array}{l}\text { Gargo Glacier, } \\
\text { Gilgit Agency }\end{array}$ & 36.04 & 74.6 & $\sim 3100$ & soil & Older & 90 & 85 & 285 & ... & 95.4 & Röthlisberger and Geyh (1986) \\
\hline & & & & & soil & Younger & 585 & 80 & 676 & 504 & 95.4 & \\
\hline & & & & & soil & Older & 3620 & 130 & 4381 & 3590 & 95.5 & \\
\hline \multirow[t]{2}{*}{ Nun Kun } & Rantac Glacier & 34.05 & 75.94 & 3100 & $\begin{array}{l}\text { Humic matter in } \\
\text { superposed } \\
\text { fossil soil on end } \\
\text { moraine }\end{array}$ & Contemporaneous & 19490 & 1630 & 28473 & 19896 & 95.4 & Röthlisberger and Geyh (1985) \\
\hline & & & & & & Younger & 15570 & 770 & 20828 & 17054 & 95.4 & \\
\hline
\end{tabular}




\begin{tabular}{|c|c|c|c|c|c|c|c|c|c|c|c|}
\hline \multirow[t]{11}{*}{ Tarangoz Glacier } & 34.05 & 75.91 & 3800 & $\begin{array}{l}\text { Humic matter in } \\
\text { fossil soil on } \\
\text { lateral moraine }\end{array}$ & Younger & 2230 & 95 & 2485 & 1952 & 95.4 & \\
\hline & & & & & Older & 3280 & 90 & 3816 & 3336 & 95.4 & \\
\hline & 34.05 & 75.91 & 3800 & $\begin{array}{l}\text { Humic matter in } \\
\text { fossil soil buried } \\
\text { by colluvium on } \\
\text { lateral moraine }\end{array}$ & Younger & 2395 & 170 & 2843 & 2005 & 95.4 & \\
\hline & & & & & Younger & 3630 & 105 & 4247 & 3642 & 95.4 & \\
\hline & 34.06 & 75.93 & 3150 & $\begin{array}{l}\text { Humic matter in } \\
\text { organic horizon } \\
\text { in loess on } \\
\text { lateral moraine }\end{array}$ & Younger & 4680 & 60 & 5583 & 5307 & 95.4 & \\
\hline & & & & & Younger & 4860 & 60 & 5731 & 5469 & 95.4 & \\
\hline & 34.05 & 75.91 & 3900 & $\begin{array}{l}\text { Humic matter in } \\
\text { fossil soil within } \\
\text { lateral moraine }\end{array}$ & Younger & 7405 & 185 & 8590 & 7862 & 95.4 & \\
\hline & & & & & Younger & 12750 & 190 & 16216 & 14189 & 95.4 & \\
\hline & 34.06 & 75.93 & 3425 & $\begin{array}{l}\text { Buried soil in } \\
\text { loess overlaying } \\
\text { moraine }\end{array}$ & Younger & 1620 & 40 & 1607 & 1408 & 95.4 & Lee et al. (2013) \\
\hline & & & & & Younger & 3150 & 40 & 3455 & 3265 & 95.4 & \\
\hline & & & & & Younger & 4480 & 40 & 5298 & 4975 & 95.4 & \\
\hline \multirow[t]{4}{*}{ Taragoz Glacier } & 75.91 & 34.05 & 3800 & soil & Older & 2230 & 95 & 2485 & 1952 & 95.4 & Röthlisberger and Geyh (1986) \\
\hline & & & & soil & Younger & 3280 & 90 & 3816 & 3336 & 95.4 & \\
\hline & & & & soil & Older & 7505 & 185 & 8750 & 7940 & 95.4 & \\
\hline & & & & soil & Younger & 12750 & 1909 & 21950 & 10733 & 95.4 & \\
\hline \multirow[t]{2}{*}{ Risla Glacier } & 76.01 & 33.63 & 3700 & soil & Older & 3210 & 80 & 3634 & 3261 & 95.4 & \\
\hline & & & & soil & Younger & 3660 & 185 & 4520 & 3487 & 95.4 & \\
\hline \multirow[t]{5}{*}{ Kolohoi Glacier } & 75.32 & 34.27 & 3870 & soil & Older & 2190 & 90 & 2354 & 1950 & 95.4 & \\
\hline & & & & soil & Younger & 2440 & 60 & 2711 & 2352 & 95.4 & \\
\hline & & & & wood & Contemporaneous & 2575 & 80 & 2844 & 2364 & 95.3 & \\
\hline & & & & soil & Older & 2695 & 160 & 3210 & 2360 & 95.4 & \\
\hline & & & & soil & Younger & 3490 & 100 & 4074 & 3482 & 95.4 & \\
\hline
\end{tabular}




\begin{tabular}{|c|c|c|c|c|c|c|c|c|c|c|c|c|}
\hline Lahul & Chandra Tal & 32.47 & 77.61 & 4300 & $\begin{array}{l}\text { Basal peat layer } \\
\text { over moraine }\end{array}$ & Younger & 9160 & 70 & 10509 & 10212 & 95.4 & Owen et al. (1997) \\
\hline & & & & & & Younger & & & & & & \\
\hline \multirow[t]{6}{*}{ Langtang Himal } & Langtang Valley & 28.2 & 85.5 & $\sim 3700$ & $\begin{array}{l}\text { Organic matter } \\
\text { in soil on } \\
\text { terminal } \\
\text { moraines }\end{array}$ & Younger & 550 & 70 & 665 & 500 & 95.4 & Shiraiwa and Watanabe (1991) \\
\hline & & & & & & Younger & 2800 & 110 & 3244 & 2741 & 95.4 & \\
\hline & & & & & & Younger & 2850 & 140 & 3356 & 2745 & 95.4 & \\
\hline & & & & & & Younger & 2980 & 110 & 3399 & 2865 & 95.4 & \\
\hline & & & & & & Older & 3650 & 320 & 4868 & 3214 & 95.4 & \\
\hline & & & & & $\begin{array}{l}\text { Wood (not in } \\
\text { situ) }\end{array}$ & Younger & 3860 & 110 & 4572 & 3929 & 95.4 & \\
\hline \multirow[t]{5}{*}{ Nepal } & $\begin{array}{c}\text { Gangapurna N. } \\
\text { Glacier }\end{array}$ & 84.01 & 28.64 & 3680 & wood in situ & Older & 135 & 50 & 283 & 0 & 95.4 & Röthlisberger and Geyh (1986) \\
\hline & & & & & soil & Older & 1210 & 55 & 1274 & 986 & 95.4 & \\
\hline & & & & & soil & Younger & 2330 & 45 & 2666 & 2160 & 95.5 & \\
\hline & & & & & soil & Older & 2955 & 105 & 3373 & 2860 & 95.4 & \\
\hline & & & & & soil & Younger & 4560 & 280 & 5904 & 4522 & 95.4 & \\
\hline \multirow[t]{2}{*}{ Khumbu Himal } & Khumbu Glacier & 27.9 & 86.8 & $\sim 4600$ & $\begin{array}{l}\text { Charcoal in } \\
\text { outwash } \\
\text { terraces } \\
\text { associated with } \\
\text { moraines }\end{array}$ & Younger & 550 & 85 & 680 & 335 & 95.4 & Benedict (1976) \\
\hline & & & & & $\begin{array}{l}\text { Charcoal and soil } \\
\text { humates in } \\
\text { outwash } \\
\text { terraces } \\
\text { associated with } \\
\text { moraines }\end{array}$ & Younger & 530 & 165 & 897 & -2 & 95.3 & \\
\hline
\end{tabular}


Khumbu 1 Glacier

Khumbu 1 Glacier

Khumbu 2a Glacier

Khumbu $2 b$ Glacier

Kyuwo 3 Glacier no data

Llotse Nup 1 Glacie $\quad 86.895$

27.9225

Nupse 1 Glacier $\quad 86.87277778 \quad 27.92777778$
Charcoal and
shrub fragment
in outwash
sands associate
with moraines

\begin{tabular}{cccccccc}
$\begin{array}{c}\text { Wood in } \\
\text { moraine }\end{array}$ & Younger & 410 & 110 & 654 & -2 & 95.4 & Fushimi (1978) \\
& Younger & 2640 & 170 & 3207 & 2342 & 95.4 & \\
\multirow{2}{*}{ Lateral moraine } & Younger & 480 & 80 & 653 & 317 & 95.4 & Muller (1980) \\
& Younger & 1150 & 80 & 1262 & 931 & 95.4 &
\end{tabular}

soil

older

$$
960
$$

Older

Older

Older

Older

Younger

Younger

Younger

Older

Older

Younger

Younger

Younger

Younger

Contemporaneous

$$
\text { Younger }
$$

Older

Older

Older

Contemporaneous

Contemporaneous

Younger
1155

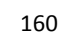

$1348 \quad 7$

95.4

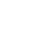

1050

$\begin{array}{llll}1050 & 728 \quad 95.4 \quad \text { Röthlisberger and Geyh (1986) }\end{array}$

$\begin{array}{lll}1415 & 962 & 95.4\end{array}$

$\begin{array}{lll}1380 & 1076 & 95.4\end{array}$

$\begin{array}{lll}1538 & 1142 & 95.4\end{array}$

$\begin{array}{lll}1813 & 1316 & 95.4\end{array}$

$\begin{array}{lll}2713 & 1873 \quad 95.4\end{array}$

$\begin{array}{lll}2749 & 1834 & 95.4\end{array}$

$\begin{array}{lll}2964 & 2208 & 95.4\end{array}$

$\begin{array}{lll}2995 & 2355 & 95.4\end{array}$

$\begin{array}{lll}3203 & 2352 & 95.4\end{array}$

$\begin{array}{lll}4294 & 2364 & 95.4\end{array}$

$\begin{array}{lll}5271 & 2314 & 95.4\end{array}$

$\begin{array}{lll}1262 & 931 & 95.4\end{array}$

$\begin{array}{lll}653 & 317 & 95.4\end{array}$

$\begin{array}{lll}644 & 153 & 95.5\end{array}$

$\begin{array}{lll}1292 & 936 & 95.4\end{array}$

$\begin{array}{lll}1226 & 725 & 95.4\end{array}$

$\begin{array}{lll}1384 & 789 & 95.4\end{array}$

$\begin{array}{lll}1893 & 1279 & 95.4\end{array}$

$\begin{array}{lll}5576 & 1986 & 95.4\end{array}$

$\begin{array}{lll}5213 & 2459 & 95.4\end{array}$

$655-515-95.4$

$\begin{array}{lll}7245 & 3700 & 95.4\end{array}$ 


\begin{tabular}{|c|c|c|c|c|c|c|c|c|c|c|c|c|}
\hline & & & & & soil & Older & 5575 & 500 & 7555 & 5323 & 95.4 & \\
\hline & Llotse Shar 1 & & & & & & & & & & & \\
\hline & Glacier & 86.95 & 27.91 & 5170 & organics & Older & 610 & 40 & 660 & 541 & 95.4 & \\
\hline & & & & & soil & Older & 775 & 110 & 922 & 553 & 95.4 & \\
\hline & & & & & organics & Younger & 1135 & 70 & 1242 & 928 & 95.4 & \\
\hline & & & & & soil organic fragmer & Younger & 1205 & 55 & 1269 & 984 & 95.4 & \\
\hline & & & & & soil & Older & 1705 & 95 & 1860 & 1403 & 95.4 & \\
\hline & & & & & soil & Younger & 2195 & 160 & 2704 & 1830 & 95.4 & \\
\hline \multirow[t]{2}{*}{ Bhutan Himalaya } & $\begin{array}{l}\text { Raphsthreng } \\
\text { Glacier, upper } \\
\text { reaches of Lingshi } \\
\text { Chu (River) and } \\
\text { Goyok Chu }\end{array}$ & 90 & 28 & $\sim 4600$ & $\begin{array}{l}\text { Humid soil } \\
\text { buried in a } \\
\text { terminal } \\
\text { moraine }\end{array}$ & Younger & 1710 & 40 & 1709 & 1535 & 95.4 & Iwata et al. (2002) \\
\hline & & & & & & Younger & 2120 & 40 & 2302 & 1992 & 95.4 & \\
\hline Everest & Rongbuk valley & & & & $\begin{array}{l}\text { Carbonate } \\
\text { precipitate on } \\
\text { clast }\end{array}$ & Younger & 3170 & 70 & 3563 & 3220 & 95.4 & Mann et al. (1996) \\
\hline \multirow[t]{3}{*}{ Namche Barwa } & & 29.63 & 95.63 & 2950 & $\begin{array}{l}\text { Wood in a } \\
\text { terminal } \\
\text { moraine in front } \\
\text { of Zelongnong } \\
\text { Glacier }\end{array}$ & Younger & 287 & 93 & 514 & -4 & 95.4 & $\begin{array}{l}\text { Zhang (1988), Chinese } \\
\text { Academy of Sciences (1996) }\end{array}$ \\
\hline & & & & & & Younger & 394 & 83 & 552 & 159 & 95.4 & \\
\hline & & & & & & Younger & 1481 & 134 & 1705 & 1094 & 95.4 & \\
\hline \multirow[t]{2}{*}{ Qilian Shan } & $\begin{array}{l}\text { Baishui River } \\
\text { valley }\end{array}$ & $\sim 38.4$ & $\sim 98.7$ & $\sim 4500$ & $\begin{array}{l}\text { Humic matter in } \\
\text { buried soil } \\
\text { interlayer in } \\
\text { lower part of an } \\
\text { overlapped } \\
\text { terminal } \\
\text { moraines }\end{array}$ & Contemporaneous & 2530 & 120 & 2856 & 2341 & 95.4 & Wu $(1984 a, b)$ \\
\hline & & & & & & Contemporaneous & 3110 & 120 & 3607 & 2972 & 95.4 & \\
\hline
\end{tabular}




\begin{tabular}{|c|c|c|c|c|c|c|c|c|c|c|c|c|}
\hline & Dunde ice cap & $\sim 38.1$ & 94.4 & $\sim 4800$ & $\begin{array}{l}\text { Humic matter in } \\
\text { a lacustrine } \\
\text { interlayer in a } \\
\text { terminal } \\
\text { moraines }\end{array}$ & Older & 8455 & 265 & 10194 & 8774 & 95.4 & Li and Jiao (1990) \\
\hline \multirow[t]{2}{*}{ West Kunlun } & $\begin{array}{l}\text { Keliya and North } \\
\text { glaciers, Chongce } \\
\text { ice cap }\end{array}$ & $\sim 35.3$ & $\sim 81.5$ & $\sim 5600$ & $\begin{array}{c}\text { Humic matter in } \\
\text { a lacustrine } \\
\text { interlayer in } \\
\text { terminal } \\
\text { morianes }\end{array}$ & Older & 8134 & 176 & 9470 & 8605 & 95.4 & Jiao and Zheng (2006) \\
\hline & & & & & & Older & 8287 & 160 & 9549 & 8776 & 95.4 & \\
\hline \multirow[t]{2}{*}{ East Kunlun } & $\begin{array}{l}\text { Guoluo Glacier, } \\
\text { Bayanhar Mt. }\end{array}$ & $\sim 33$ & $\sim 101$ & 4100 & $\begin{array}{c}\text { Humic matter } 40 \\
60 \mathrm{~cm} \text { deep in } \\
\text { two terminal } \\
\text { moraines }\end{array}$ & Younger & 2540 & 110 & 2845 & 2349 & 95.4 & Zheng et al. (1995) \\
\hline & & 33 & $\sim 101$ & $\sim 4100$ & & Younger & 4090 & 95 & 4850 & 4305 & 95.4 & \\
\hline \multirow[t]{3}{*}{ Tanggula } & Gaerqu River & c & c & c & $\begin{array}{l}\text { Humic matter at } \\
\text { the bottom of } \\
\text { soil covering } \\
\text { terminal } \\
\text { moraines }\end{array}$ & Earlier than & 2690 & 110 & 3140 & 2467 & 95.3 & $\begin{array}{c}\text { Jiao and Shen (2006) cited in Ti } \\
\text { et al. (2008) }\end{array}$ \\
\hline & & & & & & Earlier than & 5410 & 225 & 6674 & 5662 & 95.4 & \\
\hline & Page Glacier & 32 & 95 & $4200-4300$ & $\begin{array}{l}\text { Lichen ages on } \\
\text { three end } \\
\text { moraines }\end{array}$ & Minimum & $\begin{array}{l}1809 \\
1857- \\
1888 \\
1920\end{array}$ & & & & & Li et al. (1986) \\
\hline \multirow[t]{6}{*}{$\begin{array}{c}\text { Eastern } \\
\text { Nyainquentanglha }\end{array}$} & Zepu Glacier & 30.3 & 95.15 & 2960 & $\begin{array}{l}\text { Detrital wood, } \\
\text { trees in } \\
\text { moraines, } \\
\text { charcoal and } \\
\text { humic soil in } \\
\text { moraines, Zepu } \\
\text { Glacier }\end{array}$ & Minimum & 190 & 80 & 430 & -4 & 95.4 & $\begin{array}{l}\text { Jiao and Iwata (1993); Iwata } \\
\text { and Jiao (1993); Jiao et al. } \\
\text { (2005) }\end{array}$ \\
\hline & & & & 3400 & & Younger & 197 & 80 & 432 & -4 & 95.4 & \\
\hline & & & & 3300 & & Younger & 580 & 130 & 767 & 315 & 95.4 & \\
\hline & & & & $>3000$ & & Younger & 720 & 210 & 1120 & 306 & 95.4 & \\
\hline & & & & $>3000$ & & Younger & 950 & 120 & 1167 & 670 & 95.5 & \\
\hline & & & & 3200 & & Younger & 1056 & 115 & 1256 & 737 & 95.4 & \\
\hline
\end{tabular}




\begin{tabular}{|c|c|c|c|c|c|c|c|c|c|c|c|c|}
\hline & & & & $>3000$ & & Younger & 1100 & 160 & 1305 & 725 & 95.4 & \\
\hline & & & & $>3000$ & & Younger & 1570 & 300 & 2302 & 923 & 95.4 & \\
\hline & & & & $>3000$ & & Younger & 3242 & 101 & 3716 & 3220 & 95.4 & \\
\hline & \multirow[t]{3}{*}{ Arza Glacier } & 29.77 & 95.7 & $\sim 3850$ & $\begin{array}{l}\text { Wood in a } \\
\text { lateral moraine, } \\
\text { Arza Glacier }\end{array}$ & Younger & 2980 & 150 & 3470 & 2785 & 95.4 & Li et al. (1986) \\
\hline & & & & $\sim 3835$ & $\begin{array}{c}\text { Tree branches } \\
\text { buried in lateral } \\
\text { moraine }\end{array}$ & Younger & 1820 & 100 & 1987 & 1530 & 95.4 & Wang and Fan (1987) \\
\hline & & & & $\sim 3820$ & $\begin{array}{l}\text { Extreme growth } \\
\quad \text { of trees on } \\
\text { lateral moraines }\end{array}$ & Younger & $\begin{array}{c}1813- \\
1852 \\
18884- \\
1908 \\
1960\end{array}$ & & & & & Wang and Fan (1987) \\
\hline & \multirow[t]{4}{*}{ Ruoguo Glacier } & \multirow[t]{4}{*}{30.3} & \multirow[t]{4}{*}{94.73} & 3960 & $\begin{array}{c}\text { Wood in a } \\
\text { moraine, } \\
\text { Ruoguo Glacier }\end{array}$ & Younger & 1920 & 110 & 2143 & 1573 & 95.4 & $\begin{array}{l}\text { Li et al. (1986), Zheng and Li } \\
\text { (1986) }\end{array}$ \\
\hline & & & & 3880 & & Younger & 1740 & 85 & 1870 & 1418 & 95.4 & Li et al. (1986) \\
\hline & & & & 3820 & & Younger & 1540 & 85 & 1610 & 1295 & 95.4 & Li et al. (1986) \\
\hline & & & & 3640 & $\begin{array}{l}\text { Lichen dates on } \\
\text { moraine }\end{array}$ & Younger & $1822 \mathrm{AD}$ & & & & & \\
\hline & Bomi Glacier & 29.77 & 95.7 & 4000 & Age of trees & Contemporaneous & $\begin{array}{c}1580- \\
1590 \\
1860-1890\end{array}$ & & & & & Bräuning (2006) \\
\hline & Laigu Glacier & 29.33 & 96.8 & $\sim 4000$ & $\begin{array}{l}\text { Buried tree in } \\
\text { lateral moraine }\end{array}$ & $\begin{array}{c}\text { Contemporaneous/ } \\
\text { maximum }\end{array}$ & 1150 & 80 & 1262 & 931 & 95.4 & Wang and Fang (1987) \\
\hline & Luzi Glacier & not provided & not provided & 5100 & $\begin{array}{l}\text { Humic matter in } \\
\text { soil } 1-2 \mathrm{~m} \text { below } \\
\text { the turf on the } \\
\text { terminal } \\
\text { moraine }\end{array}$ & $\begin{array}{c}\text { Earlier } \\
\text { than/minimum }\end{array}$ & 3050 & 100 & 3461 & 2961 & 95.4 & Zheng (2006) \\
\hline Qiangtang Plateau & & 32.61 & 89.77 & $\sim 4900$ & $\begin{array}{l}\text { Humic matter in } \\
\text { an exposure of a } \\
\text { terminal } \\
\text { moraine, } \\
\text { Gangzari Mt. }\end{array}$ & Contemporaneous & 5760 & 170 & 7001 & 6212 & 95.4 & Li and Li (1992) \\
\hline Hengduan Mountains & $\begin{array}{c}\text { Hailuogou } \\
\text { Glacier, Gonga } \\
\text { Shan }\end{array}$ & 29.6 & 101.95 & 2850 & $\begin{array}{c}\text { Wood in lateral } \\
\text { and terminal } \\
\text { moraines }\end{array}$ & Younger & 150 & 60 & 288 & -2 & 95.4 & $\begin{array}{l}\text { Li et al. (1986); Zheng and Ma } \\
\text { (1994) }\end{array}$ \\
\hline
\end{tabular}




\begin{tabular}{|c|c|c|c|c|c|c|c|c|c|c|c|}
\hline & & & 2730 & & Younger & 540 & 70 & 665 & 489 & 95.4 & \\
\hline & & & 3000 & & Younger & 780 & 90 & 916 & 560 & 95.4 & \\
\hline & & & 2930 & & Younger & 940 & 50 & 933 & 740 & 95.4 & \\
\hline & & & $\sim 2900$ & & Younger & 1160 & 50 & 1234 & 960 & 95.4 & \\
\hline & & & 3000 & & Younger & 1550 & 80 & 1610 & 1300 & 95.4 & \\
\hline & & & 2750 & & Younger & 1580 & 60 & 1607 & 1345 & 95.4 & \\
\hline & & & $\sim 3000$ & & Older & 2170 & 110 & 2433 & 1877 & 95.4 & \\
\hline & & & $\sim 3000$ & & Older & 2350 & 65 & 2702 & 2159 & 95.3 & \\
\hline & & & 2980 & & Younger & 3080 & 80 & 3467 & 3065 & 95.4 & \\
\hline & & & $\sim 3050$ & $\begin{array}{c}\text { Black clay at the } \\
\text { bottom of } \\
\text { lacustrine } \\
\text { sediment } \\
\text { between two } \\
\text { moraines }\end{array}$ & Older & 8010 & 150 & 9396 & 8482 & 95.5 & Zheng and Ma (1995) \\
\hline \multirow[t]{5}{*}{ Diancangshan } & 25.67 & 100.09 & 3985 & $\begin{array}{l}\text { Organic silt over } \\
\text { laying moraines }\end{array}$ & Younger & 1310 & 60 & 1315 & 1075 & 95.4 & Yang et al. (2006) \\
\hline & 25.67 & 100.09 & 4041 & & Younger & 1600 & 110 & 1769 & 1296 & 95.4 & \\
\hline & 25.72 & 100.07 & 4021 & & Younger & 3240 & 60 & 3615 & 3358 & 95.4 & \\
\hline & 25.72 & 100.07 & 4012 & & Younger & 3960 & 60 & 4778 & 4184 & 95.4 & \\
\hline & 25.67 & 100.09 & 3941 & & $\begin{array}{l}\text { Younger } \\
\text { Younger }\end{array}$ & 4830 & 60 & 5709 & 5330 & 95.4 & \\
\hline Lhamcoka Glacier & 31.82 & 99.12 & $4150-4370$ & $\begin{array}{c}\text { Maximum tree } \\
\text { ages on } \\
\text { moraines }\end{array}$ & Younger & $\begin{array}{c}1760- \\
1780 \\
1807- \\
1820 \\
1907-1920\end{array}$ & & & & & Bräuning (2006) \\
\hline \multirow[t]{5}{*}{ Yanzigou Glacier } & 29.63 & 101.9 & $3850-3900$ & $\begin{array}{l}\text { Willow trunk in } \\
\text { paleosol } \\
\text { between two } \\
\text { tills }\end{array}$ & Contemporaneous & 145 & 100 & 429 & $\ldots$ & 95.4 & Smiraglia (1997) \\
\hline & & & & & Contemporaneous & 235 & 110 & 485 & -3 & 95.4 & \\
\hline & & & & & Contemporaneous & 1305 & 110 & 1405 & 975 & 95.4 & \\
\hline & & & & & Contemporaneous & 1610 & 65 & 1691 & 1358 & 95.4 & \\
\hline & & & & & Contemporaneous & 1785 & 65 & 1865 & 1558 & 95.4 & \\
\hline
\end{tabular}




\begin{tabular}{ccccccccccccc} 
Nanmenguangou & 29.67 & 101.98 & 3000 & $\begin{array}{c}\text { Buried rotten } \\
\text { wood in till }\end{array}$ & Contemporaneous & 780 & 90 & 916 & 560 & 95.4 & Zheng and Ma (1994) \\
Gongba Glacier & 30.5 & 101.87 & 3900 & $\begin{array}{c}\text { Buried rotten } \\
\text { wood in till }\end{array}$ & Contemporaneous & 440 & 50 & 545 & 319 & 95.4 & Su et al. (2002) \\
& & & & & Contemporaneous & 620 & 40 & 662 & 546 & 95.4 & \\
\hline
\end{tabular}

Notes

${ }^{a}$ Radiocarbon ages calibrated using OxCal 4.2 applying IntCal 09

${ }^{\mathrm{b}}$ Exact location not described in paper, so values are very approximate

${ }^{c}$ Exact locations not provided. Ages do not readily match with original publication (in Chinese). 
Table 2

Major optically stimulated luminescence dating projects that has been undertaken for glacial geologic studies in the Himalayan-Tibetan orogen

Area Source

Ateaoyinake River Valley, Tianshan ${ }^{1}$

Bogeda Peak area, Tianshan ${ }^{1}$

Terskey-Alatoo Range, Kyrgyz Republic

Tien Shan, Yrgyz Republic

Central Karakoram

Hunza valley, Karakoram Mountains

Nun Kun

Zanskar

Chitral

Swat Himalaya

Nanga Parbat

Lahul Himalaya

Garhwal Himal

Central Himalaya

Khumbu Himal

Kanchenjunga

Rongbuk valley, Everest

Kunlun Mountains

Anyemaquen Mountains
Zhao et al. (2012)

Narama et al. (2007)

Narama et al. (2009)

Seong et al. (2008)

Derbyshire et al. (1984), Spencer and Owen (2004)

Lee et al. (2013)

Taylor and Mitchell (2000)

Richards et al (2000a), Owen et al. (2002b)

Owen et al. (1992), Richards et al. (2000a)

Richards et al. (2000a)

Owen et al. (1997)

Sharma and Owen (1996)

Ali et al. (2013)

Richards et al. (2000b)

Tsukamoto et al. (2000)

Owen et al. (2009)

Owen et al. (2006b)

Owen et al. (2003a)
Material dated

Till and glaciofluvial outwash

Tills and associated sediments

Glacial and loess deposits

Glacial and loess deposits

Glaciofluviual sediment

Surpaglacial and proglacial sediments

Aeolian and colluvial deposits

Glaciofluvial sediments

Supraglacial and proglacial glaciofluvial sediments

Colluviated loess overlaying moraines

\section{Proglacial glaciofluvial} sediments

Glaciodeltaic sediments

Englacial and supraglacial glaciofluvial sediments

Outwash gravels and moraines

Supraglacial and englacial glaciofluvial sediments

Glacial sediments

Supraglacial and proglacial glaciofluvial sediments

Fluvial and aeolian sediments on terraces

Surpaglaciofluvial sediment

Notes: 1. Also includes ESR dating 
Table 3.

Summary of glacial chronologies dated by ${ }^{10} \mathrm{Be}$ methods throughout the Himalayan-Tibetan orogen listing the dating methods applied to define the ages of glacial advances.

\begin{tabular}{|c|c|c|}
\hline Study region & Study & $\begin{array}{l}\text { Glacial stage or } \\
\text { moraine name }\end{array}$ \\
\hline \multicolumn{3}{|l|}{ 1) Pamir and Tien Shan } \\
\hline \multirow{8}{*}{ Gissar Range, Western Tajikisyan } & Zech et al. (2013) & G1 \\
\hline & & G2 (not dated) \\
\hline & & G3 (not dated) \\
\hline & & G4 \\
\hline & & G5 (not dated) \\
\hline & & G6 \\
\hline & & G7 \\
\hline & & G8 \\
\hline \multicolumn{3}{|l|}{ Aksu Valley, Turkestan Range, Kyrgyzstan } \\
\hline \multirow[t]{4}{*}{ Aksu Valley, Turkestan Range, Kyrgyzstan } & Abramowski et al. (2006) & AK4 moraine \\
\hline & & AK3 moraine \\
\hline & & AK2 moraine \\
\hline & & AK1 moraine \\
\hline \multicolumn{3}{|l|}{ Koksu Valley, Alay Range Kyrgyzstan } \\
\hline \multirow[t]{2}{*}{ Koksu Valley, Alay Range Kyrgyzstan } & Abramowski et al. (2006) & $\mathrm{AV}$ moraine \\
\hline & & KK moraine \\
\hline \multicolumn{3}{|l|}{ Ailuitek Pass, north Central Pamir, Tajikistan } \\
\hline \multirow[t]{2}{*}{ Ailuitek Pass, north Central Pamir, Tajikistan } & Abramowski et al. (2006) & AT moraine \\
\hline & & TK moraine \\
\hline \multicolumn{3}{|l|}{ S-Alichur Range, Yashikul, Tajikistan } \\
\hline \multirow[t]{6}{*}{ S-Alichur Range, Yashikul, Tajikistan } & Zech et al. (2005) & M4 moraine \\
\hline & Zech et al. (2005) & M3 moraine \\
\hline & Abramowski et al. (2006) & BO1 moraine (=M3/YK3 of Zech et al. 2005) \\
\hline & Zech et al. (2005) & M2 moraine \\
\hline & Abramowski et al. (2006) & BO2 moraine ( $=\mathrm{M} 2 / \mathrm{YK} 2$ of Zech et al. 2005) \\
\hline & Zech et al. (2005) & M1 moraine \\
\hline \multicolumn{3}{|l|}{ S-Alichur Range, Kol-Uchkol, Tajikistan } \\
\hline \multirow[t]{6}{*}{ S-Alichur Range, Kol-Uchkol, Tajikistan } & Abramowski et al. (2006) & UK6 moraine \\
\hline & & UK5 moraine \\
\hline & & UK4 moraine \\
\hline & & UK3 moraine \\
\hline & & UK2 moraine \\
\hline & & UK1 moraine \\
\hline \multicolumn{3}{|l|}{ S-Alichur Range, Gurumdy, Tajikistan } \\
\hline \multirow[t]{4}{*}{ S-Alichur Range, Gurumdy, Tajikistan } & Abramowski et al. (2006) & GU4 moraine \\
\hline & & GU3 moraine \\
\hline & & GU2 moraine \\
\hline & & GU1 moraine \\
\hline \multicolumn{3}{|l|}{ Bogchigir Range, Pamir Tajikistan } \\
\hline \multirow[t]{8}{*}{ Bogchigir Range, Pamir Tajikistan } & Röhringer et al. (2012) & во8 \\
\hline & & $\mathrm{BO} 7$ \\
\hline & & BO6 \\
\hline & & BO5 \\
\hline & & $\mathrm{BO} 4$ \\
\hline & & $\mathrm{BO} 3$ \\
\hline & & BO1 \\
\hline & & M1 \\
\hline Mustagata and Kongur Shan, Chinese Pamir & & \\
\hline Mustagata and Kongur Shan, Chinese Pamir & Seong et al. (2009a) & Olimde glacial stage \\
\hline & & Subaxh glacial stage \\
\hline & & Karasu glacial stage \\
\hline Tashkurgan valley, Chinese Pamir & & \\
\hline Tashkurgan valley, Chinese Pamir & Owen et al. (2012) & Kuzigun \\
\hline & & Hangdi \\
\hline & & Tashkurgan \\
\hline & & Dabudaer \\
\hline W Tien Shan, Kyrgyzstan & & \\
\hline Ala Archa, Wn Tien Shan, Kyrgyzstan & Koppes et al. (2008) & v \\
\hline Aksai, Wn Tien Shan, Kyrgyzstan & & IV, V \\
\hline & & $\mathrm{IV}, \mathrm{V}$ \\
\hline & & $\mathrm{IV}, \mathrm{V}$ \\
\hline
\end{tabular}


Ala Bash, Wn Tien Shan, Kyrgyzstan Chor Kyrchak, Wn Tien Shan, Kyrgyzstan Ala Bash, Wn Tien Shan, Kyrgyzstan

Central Tien Shan, Kyrgyzstan Kitschi-Kurumdu Valley, Tien Shan, Kyrgyzstan

Urumqi River valley, En Tian Shan, China Urumqi River valley, En Tian Shan, China

2) Transhimalaya and Western Tibet Sulamu Tagh, Altyn Tagh $\mathrm{Nn}$ Tibet Sulamu Tagh, Altyn Tagh Nn Tibet

Central Karakoram (K2), Nn Pakistan Central Karakoram (K2), Nn Pakistan

Hunza valley, Karakoram Mts. Nn Pakistan Hunza valley, Karakoram Mts. Nn Pakistan

Ladahk Range, Nn India

Ladahk Range, Nn India

adakh, Nn India

Ladakh, Nn India

Nubra valley, N Ladakh

Shyok valley, N Ladakh

Puga valley, Zanskar, Nn India

Puga valley, Zanskar, Nn India

Karzok valley, Zanskar, Nn India Karzok valley, Zanskar, Nn India

Ayilari Range, Sn Tibet

Ayilari Range, SWn Tibet

Ayilari Range, SWn Tibet

Gurla Mandhata, Sn Tibet

Muguru valley, Gurla Mandhata
Zech (2012)

M1
M2
M3
M4
M5
M6
M7

Kong et al. (2009a)

Lateral moraine, Glacier Observation Station Latero-terminal moraine, lower trough, Shangwanfeng Elevated platform, Gaowangfeng

Mériaux et al. (2004)

M2 moraine

M1 moraine

Seong et al. (2007)

Askole glacial stage Mungo glacial stage Skardu glacial stage

Owen et al. (2002b)

Batura glacial stage Ghulkin II glacial stage Ghulkin I glacial stage Borit Jheel glacial stage Yunz glacial stage

Owen et al. (2006a)

Khalling glacial stage Bazgo glacial stage Kar glacial stage Leh glacial stage Indus glacial stage

Dortch et al. (in press)

Pangong cirque

Ladakh cirque Ladakh-2 stage Ladakh-4 stage Pangong-2 stage

Dortch et al. (2010a)

Deshkit 1

Deshkit 2

Deshkit 3

Hedrick et al. (2011)

PM-3

$\mathrm{PM}-2$

PM-0

Hedrick et al. (2011)

KM-4

$\mathrm{KM}-3$

KM-2

KM-1

KM-O

Chevalier et al. (2005)

M1 moraine

M2W (oldest moraine, west)

M2E (oldest moraine east)

Chevalier et al. (2011)

17b: CK M2 inner 17c; CK M2 outer

$$
\text { 17a: CK M3 }
$$

Owen et al. (2010) 
Ronggua gorge foreland, Gurla Mandhata

Chevalier et al. (2011)

Gurla Mandhata, Sn Tibet Gurla Mandhata, Sn Tibet

Kailas Range, SWn Tibet Kailas Range, SWn Tibet

Rongbuk valley, N. Mt. Everest Rongbuk valley, N. Mt. Everest

3) Monsoon-influcenced Himalaya Nanga Parbat, Nn Pakistan Nanga Parbat, Nn Pakistan

Nun Kun, Nn India Nun Kun, Nn India

Lahul Himalaya, Nn India Lahul Himalaya, Nn India

Gangotri, Garhwal Himalaya, Nn India Gangotri, Garhwal Himalaya, Nn India

Central Garhwal, Nn India Bhillangana and Dudhganag valleys, central Garhwal

Mayali, central Garhwal Kedarnath, central Garhwa

Western Garhwal Himalaya, Nn. India Tons Valley, Garhwal Himalaya, Nn. India

Pin Valley, Wn Garhwal, Nn India

Thangi Valley, Wn Garhwal, Nn India
Chevalier et al. (2011)

Owen et al. (2009)

Phillips et al. (2000)

Lee et al. (in press)

Owen et al. (2001)

Barnard et al. (2004a)

Murari et al. (in review)

Murari et al. (in review) Murari et al. (in review)

Scherler et al. (2010) 12a: Pulan M1W 12c: Pulan M1E 12B: Pulan M2

12: EXS

14: WXS

15: A Qu

Mid Holocene advance Maximum Holocene extent

MIS-3 advance

TG3
ST3
ST2
TG1
ST1
NKB1

NKB1

Kulti glacial stage Batal glacial stage

Chandra glacial stage (not dated)

$$
\begin{aligned}
& \text { Bhujbas glacial stage } \\
& \text { Gangotri glacial stage } \\
& \text { Kedar glacial stage } \\
& \text { Bhagirathi glacial stage }
\end{aligned}
$$

$$
\begin{gathered}
\mathrm{mbd} 4 \\
\mathrm{mbd} 3 \\
\mathrm{mbd} 2 \\
\mathrm{mbd} 1 \\
\mathrm{~mm} 1 \\
\mathrm{mk} 3 \\
\mathrm{mk} 3 \\
\mathrm{mk} 1
\end{gathered}
$$

Tons Valley (location G) Tons Valley (location E)

Tons Valley (location F)

Tons Valley (location F')

Tons Valley (location D)
Tons Valley (location C)

Tons Valley (location B): Gangar lateral moraine (no stage name)

Tons Valley (location B): Gangar Kame deposit

Thangi valley: Lateral moraine (no stage name)

Thangi valley: Lateral moraine (no stage name)

Pin Valley: Lateral moriane (no stage name) 
Nanda Devi, Garhwal, Nn India Nanda Devi, Garhwal, Nn Indial

Annapurna Range, Nepal Annapurna Range

Annapurna, Nepa

Dudh Khola Valley, Annapurna, Nepal

Marsyandi Valley, Annapurna, Nepal

Macha Lhola Valley, Gorkha Himal, Nepal Macha Lhola Valley, Gorkha Himal, Nepal

Milarepa's Glacier, Annapurna Range, Nepal Milarepa's Glacier, Annapurna Range, Nepal

Mailun Khola, Ganesh Himal, Nepal Mailun Khola, Ganesh Himal, Nepal

Langtang Himal, Nepal Langtang Valley, Langtang Himal, Nepal

\section{Langlang Valey, Langlang Himal, Nepal}

Nyalam County, Sn Xixabangma, Sn Tibet Nyalam County, Sn Xixabangma, Sn Tibet

Ama Drime Range, Sn Tibet

Ama Drime Range, $\mathrm{Sn}$ Tibet

Khumbu Himal, Nepal

Khumbu Himal, Nepal

Finkel et al. (2003)

Pratt-Sitaula (2004)

Pratt-Sitaula (2011)

Pratt-Sitaula (2011)

Pratt-Sitaula (2004)

Pratt-Sitaula (2004)

Pratt-Sitaula (2011)

Pratt-Sitaula (2011)

Pratt-Sitaula (2004)

Pratt-Sitaula (2004)

Zech et al. (2009)

Abramowski (2004)

Gayer et al. (2006)

Abramowski (2004)

Barnard et al. (2006)
Moraine $\mathrm{m} 4$

Moraine $\mathrm{m} 3$

Moraine $\mathrm{m} 2$

Moraine $\mathrm{m} 1$
Heimsath and McGlynn (2008)

Schaefer et al. (2008)

Chevalier et al. (2011)
Lobuche glacial stage and historical
Thuklha glacial stage
Chhukung glacial stage
Periche II glacial stage
Periche I glacial stage
Thyangboche II glacial stage
Thyangboche I glacial stage

$$
\begin{aligned}
& \text { 8: Dingye N } \\
& \text { 9b: Dingye } S \text { main \#1 } \\
& \text { 9c: Dingye S main \#2 } \\
& \text { 9d: Dingye } S \text { main \#3 } \\
& \text { 9a: Dingye S frontal }
\end{aligned}
$$

Danfe Glacier (early-mid Holocene)

Glacier (early-mid Holocene)

Glacier end (LGM)

Little Ice Age moriane

Neoglacial

MK5: Late Glacial

MK2: LGM

4) Monsoon-influenced Tibet

Xainza Range, Sn Tibet

Xainza Range, Sn Tibet

Chevalier et al. (2011)

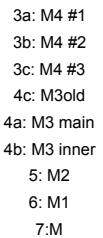


Kunlun Shan

Kunlun Shan (southern slopes)

Shan, NE Tibet

NW Menyuan, Qilian Shan, NE Tibet

Qilian Shan, NE Tibet

Xiying He valley, Qilian Shan, NE Tibet

Nianbaoyeze Mountains

Nianbaoyeze Mountains

Anyemaqen Mountains

Anyemaqen Mountains

Bayan Har, NE Tibet

Bayan Har, NE Tibet

Dalijia Shan, NE Tibet

Qital Valley, Dalijia Shan, NE Tibet

Cental Tanggula Shan

Tanggula Pass, Central Tanggula Shan

Nyainqentangglha Shan, Central Tibet SE Samdainkangsang, Nyainqentangglha Shan

Nyainqentanggula, South Central Tibet Nyainqentanggula, South Central Tibet

KungCo, Sn Tibet

KungCo, Sn Tibet

Cho Oyu Range, $\mathbf{S}$ Central Tibet

Cho Oyu Range, S Central Tibet

Shaluli Shan, Chuanxi Plateau, En Tibet Shaluli Shan, Chuanxi Plateau, En Tibet

Shaluli Shan, Haizishan Plateau, En Tibe Shaluli Shan, Haizishan Plateau, En Tibet
Owen et al. (2006b)

Owen et al. (2003c)

Laserre et al. (2002)

Owen et al. (2003a)

Owen et al. (2003a)

Heyman et al. (2011)

Colgan et al. (2006)

Owen et al. (2005), Colgan et al. (2006) Schäfer et al. (2002), Owen et al. (2005) Owen et al. (2005), Colgan et al. (2006)

Owen et al. (2005)

Chevalier et al. (2011)

2b: ybj inner

2a: ybj outer W

2c: ybj outer $\mathrm{E}$

2d: ybj outer $\mathrm{N}$

1a: Gulu W

1b: Gulu E

Chevalier et al. (2011)

11: KungCo

Chevalier et al. (2011)

10: Cho Oyo
Graf et al. (2008) includes Ne-21 too Cuo Ji Gang Wa and Cuo Naleng paleoglaciers: lateral moraine Cuo Ji Gang Wa and Cuo Naleng paleoglaciers: outer end moraine Cuo Ji Gang Wa and Cuo Naleng paleoglaciers: middle end moraine Cuo Ji Gang Wa and Cuo Naleng paleoglaciers: inner end moraine Chuanxi and northern outlet glacier: resting on $\mathrm{HAl}-2$

Chuanxi and northern outlet glacier: on smaller moraine ridge

Chuanxi and northern outlet glacier: embedded in basal till

Fu et al. (2013)

innermost moraine sequence intermediate moraine sequence outermost moraine sequence

Shaluli Shan, Xinlong Plateau, En Tibet 
Shaluli Shan, Xinlong Plateau, En Tibet

Shaluli Shan, Nata, En Tibet

Shaluli Shan, Nata, En Tibet

Shaluli Shan, Heranseba, En Tibet

Shaluli Shan, Heranseba, En Tibet

Litang County, En Tibet

Litang County, En Tibet

Hengduan Mountains, SE Tibet

Kangding, Daxue Shan, Hengduan Mts., SE Tibet

Mt. Kaluxung, Sn Tibet

Karola Pass, Mt. Kaluxung, Sn Tibet

Gangrigabu Shan, SE Tibet

Bodui Zangbo River, Gangrigabu SE Tibet

Gonga Shan, SE Tibet

Hailuogou Valley, Gonga Shan, SE Tibet

Shaluli Mountain, SE Tibet Haizi Shan, Shaluli Mountain, SE Tibet

Yulong Mountains, SE Tibet Renhe valley, Yulong Mountains, SE Tibet Xinlian valley, Yulong Mountains, SE Tibet Baishui valley, Yulong Mountains, SE Tibet Ganheba, Ganheba Mountains, SE Tibet outermost moraine sequence

outermost moraine sequence

Fu et al. (2013)

outermost moraine sequence

Schäfer et al. (2002)

Un-named moraine (youngest)

Un-named moraine (oldest)

Zhheduo valley moraine ridge

Tschudi et al. (2003), Strasky et al. (2003)

Owen et al. (2005)

Un-named (youngest) moraine Un-named (intermediate age) moraine Un-named (oldest) moraine

Zhou et al. $(2007,2010)$

East moraines: Baiyu Glaciation West younger moraine: Baiyu Glaciation West older moraine: Baiyu Glaciation Area C: Guxiang Glaciation

Monsoon Tibet

Owen et al. (2005)

Little Ice Age moraines Neoglacial moraines "Recessional moraine" Local LGM moraines

Wang et al. (2006)

Kuzhaori end moraine

Kong et al. (2009b)

Kong et al. (2009b)

Kong et al. (2009b)

Kong et al. (2009b)
No stage name given

No stage name given

No stage name given

No stage name given 


\section{Table 4}

Regional glaciers stages of Dortch et al. (2013) and Murari et al. (2013) for the semi-arid western end and the monsoonal-influenced areas of the Himalayan-Tibetan orogen, respectively. Student's T-Test is utilized to compare the populations of TCN ages between glacial stages in the two regions. The resulting P-values are presented in the middle column where bold numbers indicate failure to reject the null hypothesis and the possibility of the two stages being correlative is good. Italicized P-values indicate the regional stage is distinct from all other regional stages at $\geq 95 \%$ confidence interval; in these cases, the highest P-value is presented.

\begin{tabular}{|c|c|c|c|c|}
\hline \multicolumn{2}{|c|}{$\begin{array}{l}\text { Semi-arid western end of the } \\
\text { Himalayan-Tibetan orogen }\end{array}$} & \multirow[b]{2}{*}{ P-value } & \multicolumn{2}{|c|}{$\begin{array}{c}\text { Monsoon-influenced } \\
\text { Himalayan-Tibetan orgen }\end{array}$} \\
\hline $\begin{array}{c}\text { Regional } \\
\text { glacial stage } \\
\text { name }\end{array}$ & Age & & $\begin{array}{l}\text { Regional glacial } \\
\text { stage name }\end{array}$ & Age \\
\hline & & 0.00 & MOHITS10 & $483 \pm 38$ \\
\hline SWHTS9 & $311 \pm 32$ & 0.92 & MOHITS9 & $314 \pm 48$ \\
\hline \multirow[t]{2}{*}{ SWHTS7 } & $234 \pm 44$ & 0.18 & MOHITS7 & $192 \pm 10$ \\
\hline & & 0.04 & MOHITS6B & $168 \pm 12$ \\
\hline SWHTS6 & $146 \pm 18$ & 0.64 & MOHITS6A & $143 \pm 12$ \\
\hline \multirow[t]{2}{*}{ SWHTS5E } & $121 \pm 11$ & 0.97 & MOHITS5E & $121 \pm 5$ \\
\hline & & 0.02 & MOHITS5B & $91 \pm 15$ \\
\hline SWHTS5A & $80 \pm 5$ & 0.02 & & \\
\hline SWHTS5A- & $72 \pm 8$ & 0.00 & & \\
\hline \multirow[t]{2}{*}{ SWHTS4 } & $61 \pm 5$ & 0.12 & MOHITS4 & $68 \pm 10$ \\
\hline & & 0.00 & MOHITS3C & $55 \pm 5$ \\
\hline \multirow[t]{2}{*}{ SWHTS3 } & $46 \pm 4$ & 0.75 & MOHITS3B & $46 \pm 5$ \\
\hline & & 0.00 & MOHITS3A & $42 \pm 2$ \\
\hline \multirow[t]{2}{*}{ SWHTS2F } & $30 \pm 3$ & 0.25 & MOHITS2G & $31 \pm 3$ \\
\hline & & 0.01 & MOHITS2F & $26 \pm 2$ \\
\hline
\end{tabular}




\begin{tabular}{|c|c|c|c|c|}
\hline & & 0.00 & MOHITS2E & $22 \pm 3$ \\
\hline \multirow[t]{2}{*}{ SWHTS2E } & $20 \pm 2$ & 0.03 & & \\
\hline & & 0.03 & MOHITS2D & $18.7 \pm 1.8$ \\
\hline SWHTS2D & $16.9 \pm 0.7$ & 0.21 & MOHITS2C & $17.3 \pm 0.3$ \\
\hline SWHTS2C & $14.9 \pm 0.8$ & 0.23 & MOHITS2B & $15.5 \pm 1.3$ \\
\hline SWHTS2B & $13.9 \pm 0.5$ & 0.00 & & \\
\hline \multirow[t]{4}{*}{ SWHTS2A } & $12.2 \pm 0.8$ & 0.01 & MOHITS2A & $12.9 \pm 0.9$ \\
\hline & & 0.00 & MOHITS1K & $11.4 \pm 0.7$ \\
\hline & & 0.00 & MOHITS1J & $10.1 \pm 0.5$ \\
\hline & & 0.00 & MOHITS1I & $9.1 \pm 0.3$ \\
\hline $1 \mathrm{E}$ & $8.7 \pm 0.2$ & 0.16 & MOHITS1H & $8.1 \pm 0.8$ \\
\hline $1 \mathrm{D}$ & $6.9 \pm 0.1$ & 0.00 & MOHITS1G & $7.7 \pm 0.6$ \\
\hline Askole 1 & $5.5 \pm 0.3$ & 0.42 & MOHITS1F & $5.4 \pm 0.6$ \\
\hline $1 \mathrm{C}$ & $3.8 \pm 0.6$ & 0.37 & MOHITS1E & $3.5 \pm 0.4$ \\
\hline PM-2 & $2.8 \pm 1.2$ & 0.54 & MOHITS1D & $2.3 \pm 0.1$ \\
\hline $1 \mathrm{~B}$ & $1.7 \pm 0.2$ & 0.15 & MOHITS1C & $1.5 \pm 0.2$ \\
\hline Askole 3 & $1.1 \pm 0.1$ & 0.03 & MOHITS1B & $0.7 \pm 0.1$ \\
\hline $1 \mathrm{~A}$ & $0.4 \pm 0.1$ & 0.25 & MOHITS1C & $0.4 \pm 0.1$ \\
\hline
\end{tabular}




\section{Figure 1}

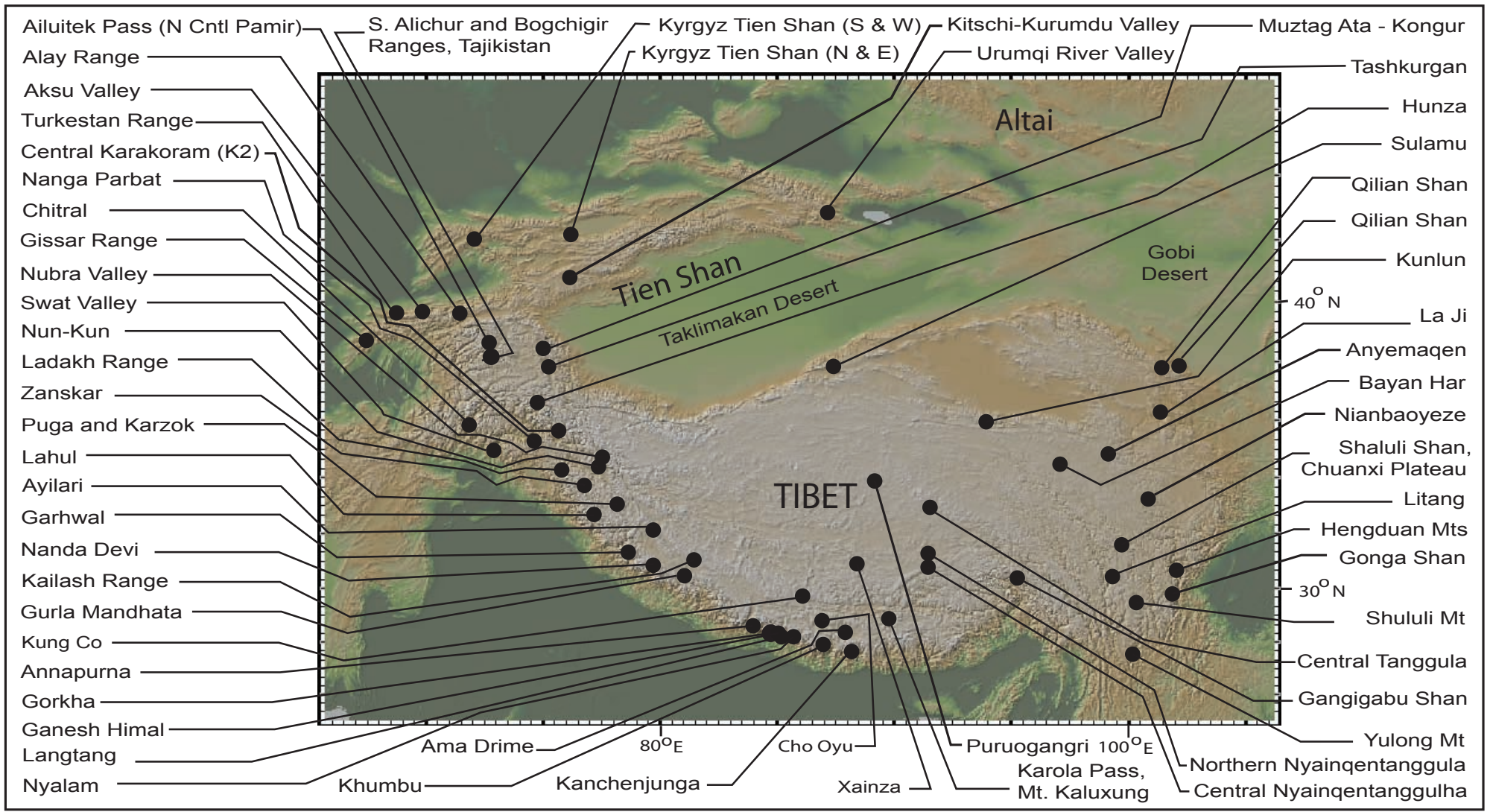

Figure 1 

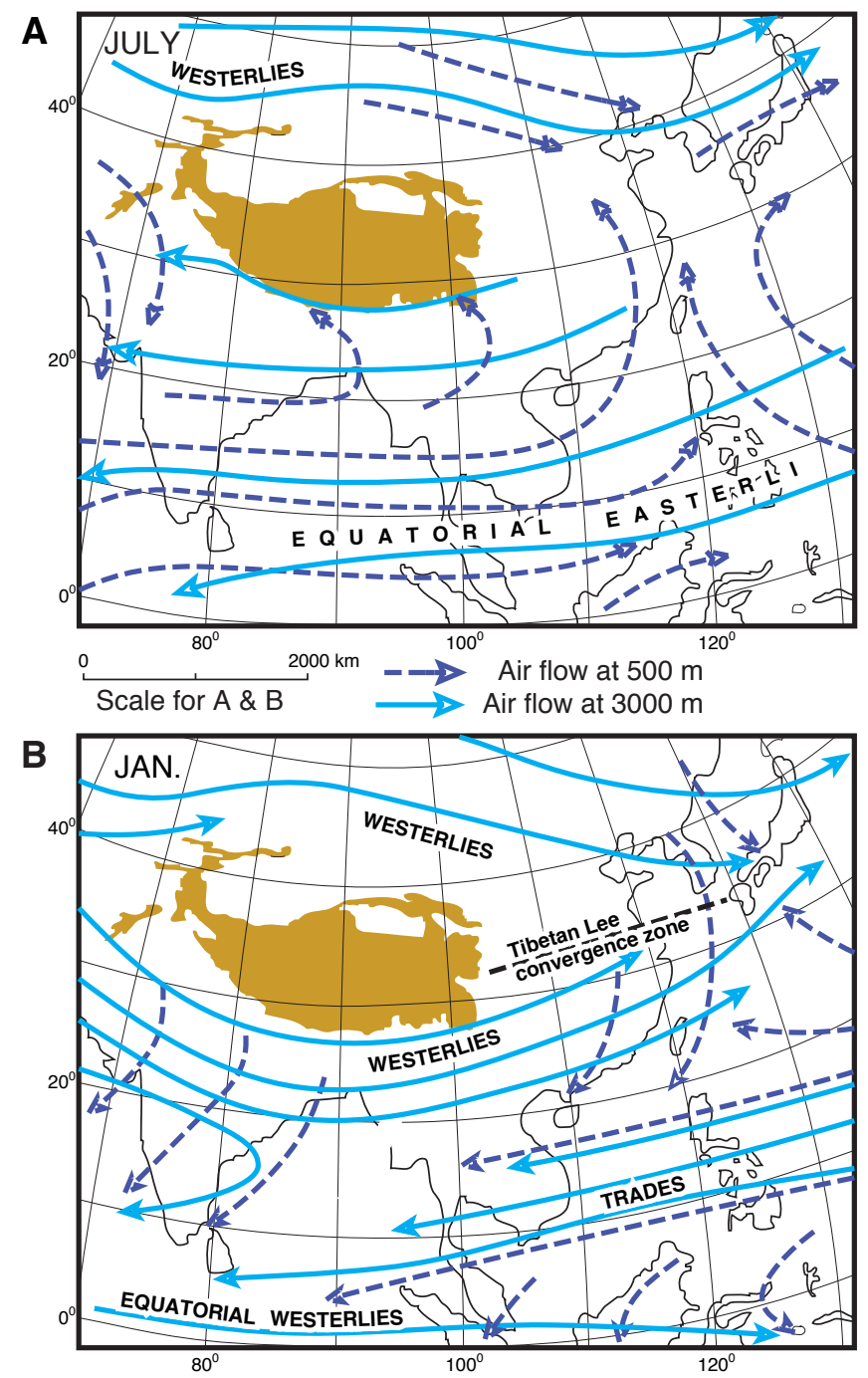

Figure 2 

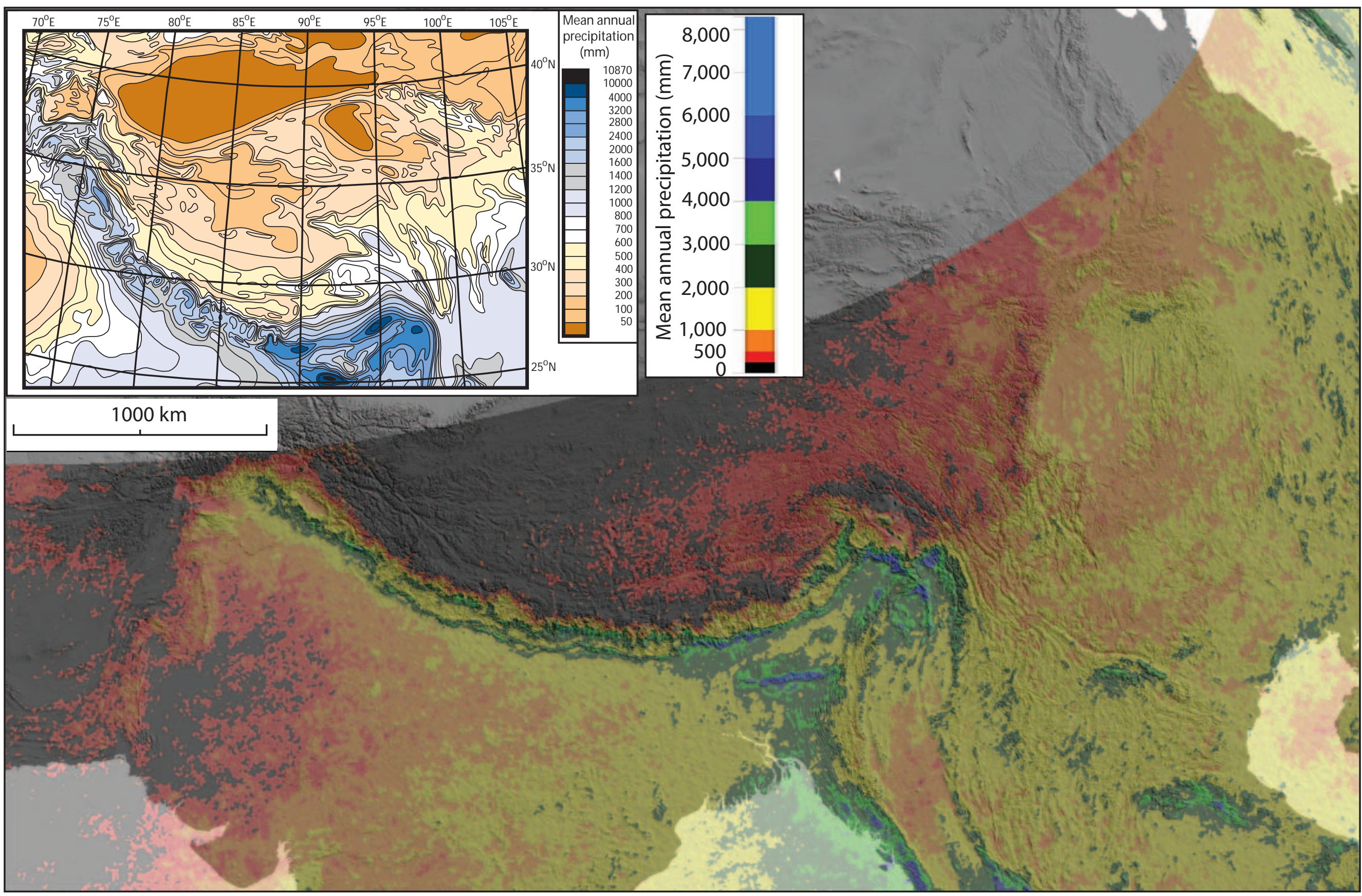

Figure 3 


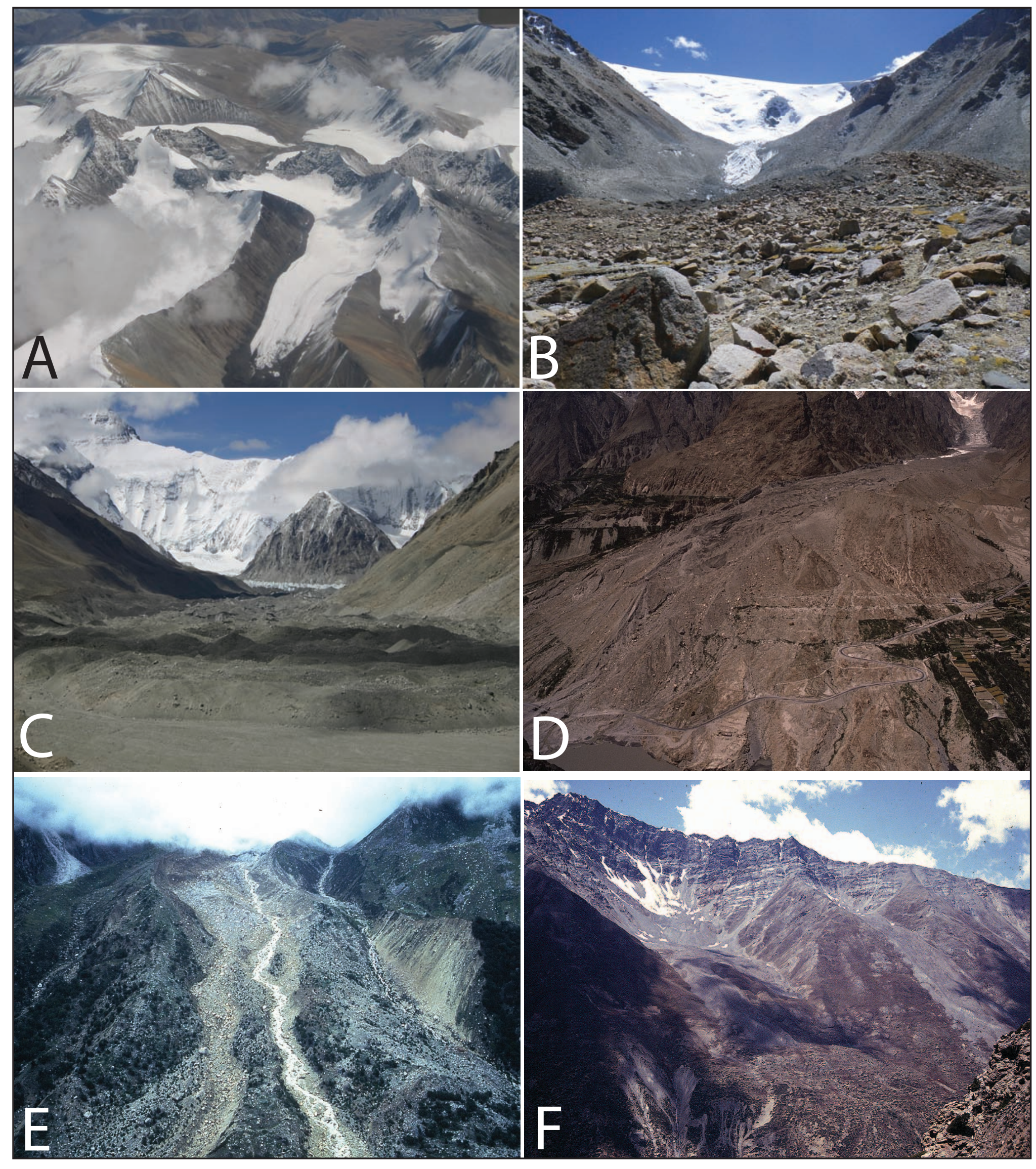

Figure 4

\section{Figure 4}



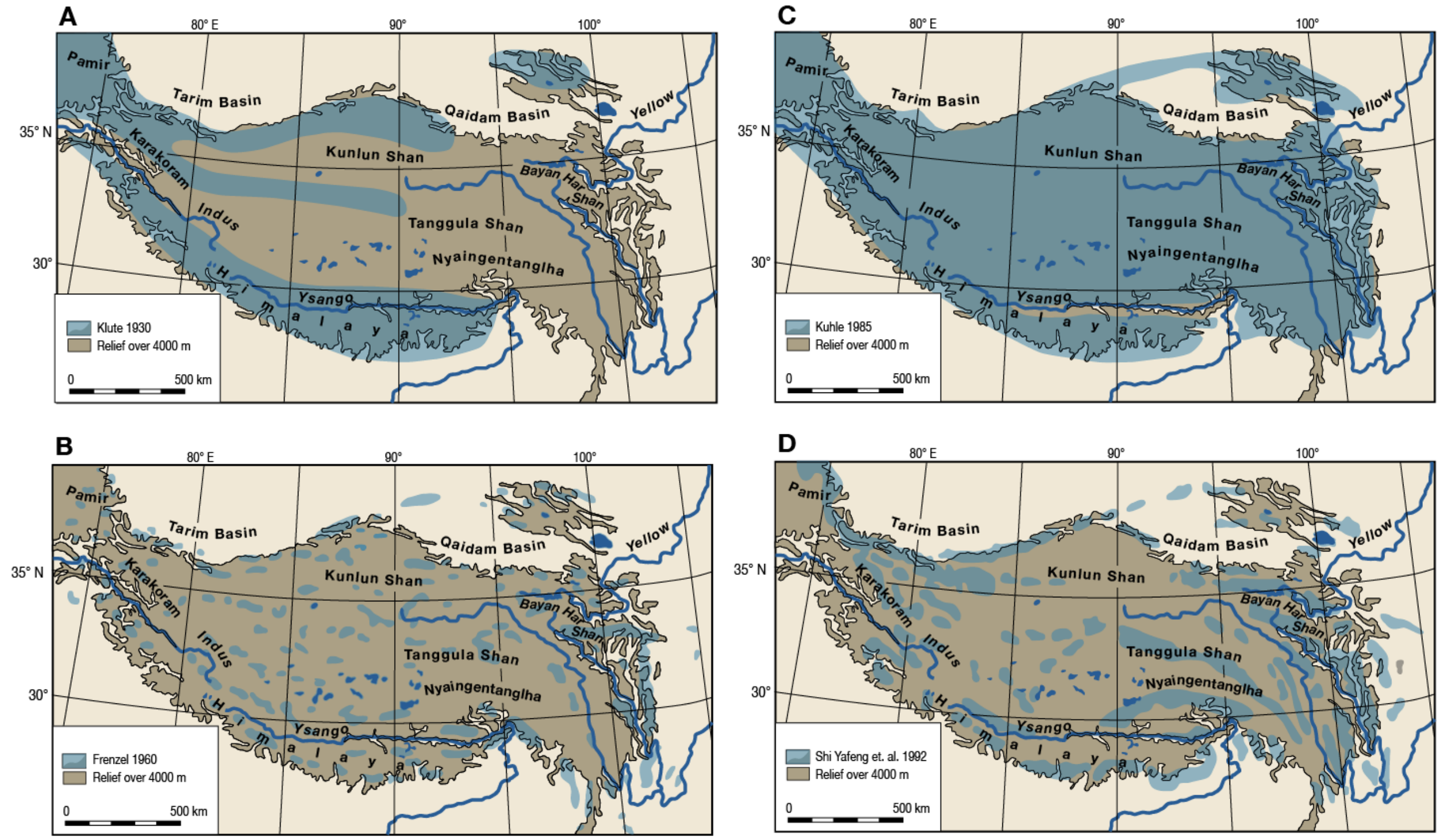

Figure 5 

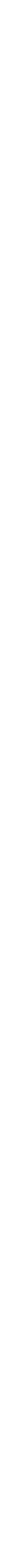

Figure 6

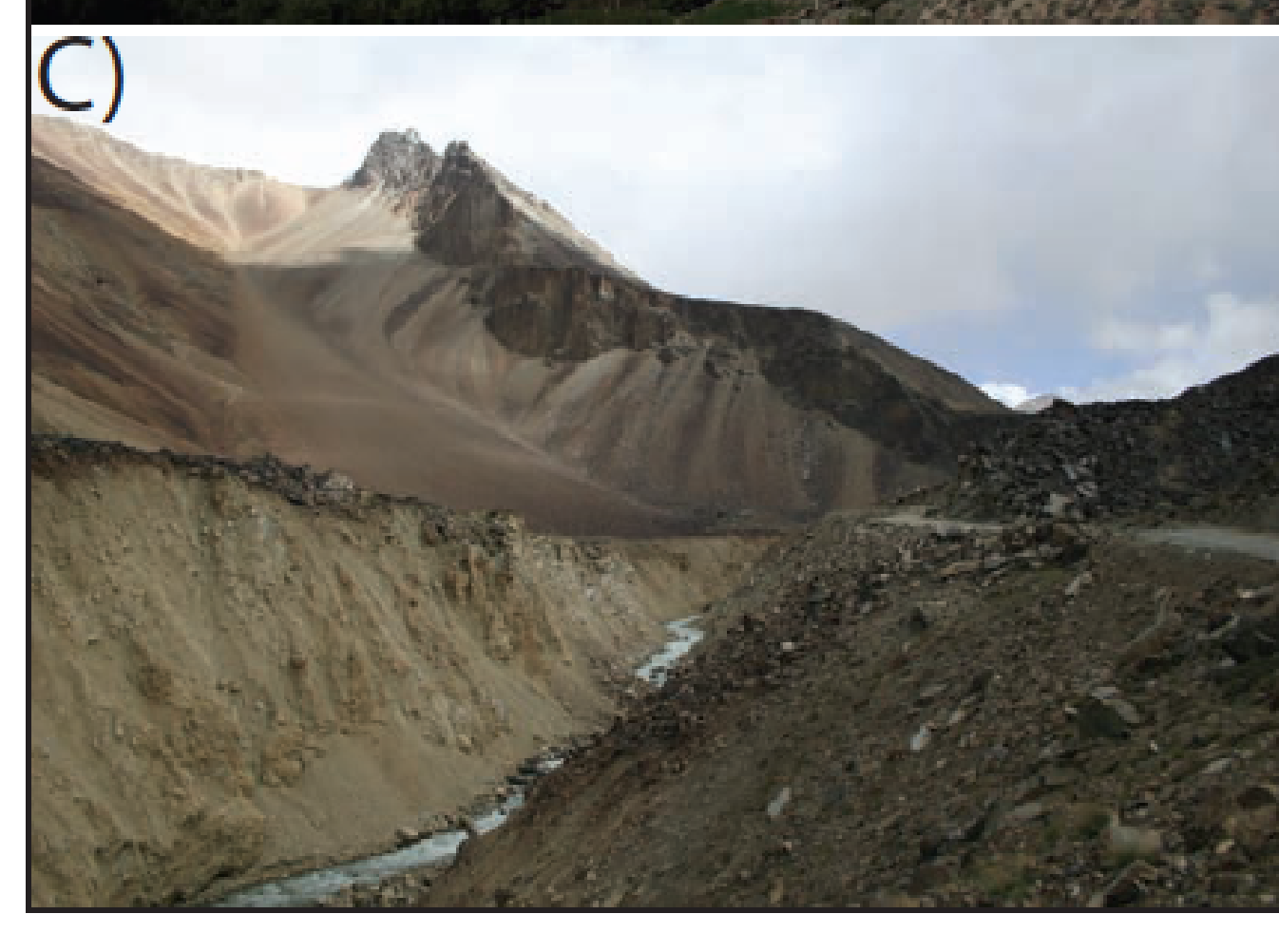

Figure 6

A)

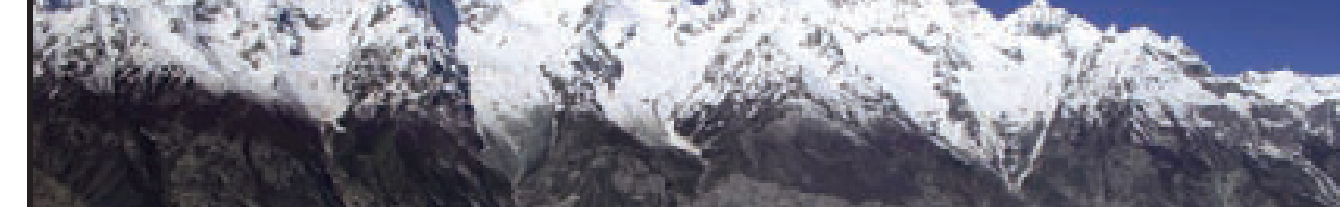

C)

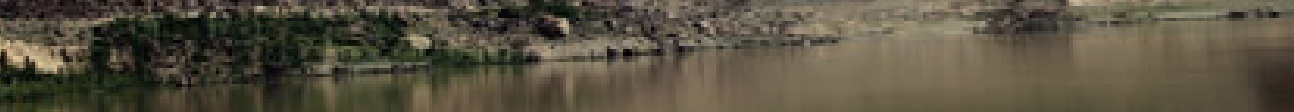

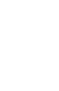

B)

.

Figure 


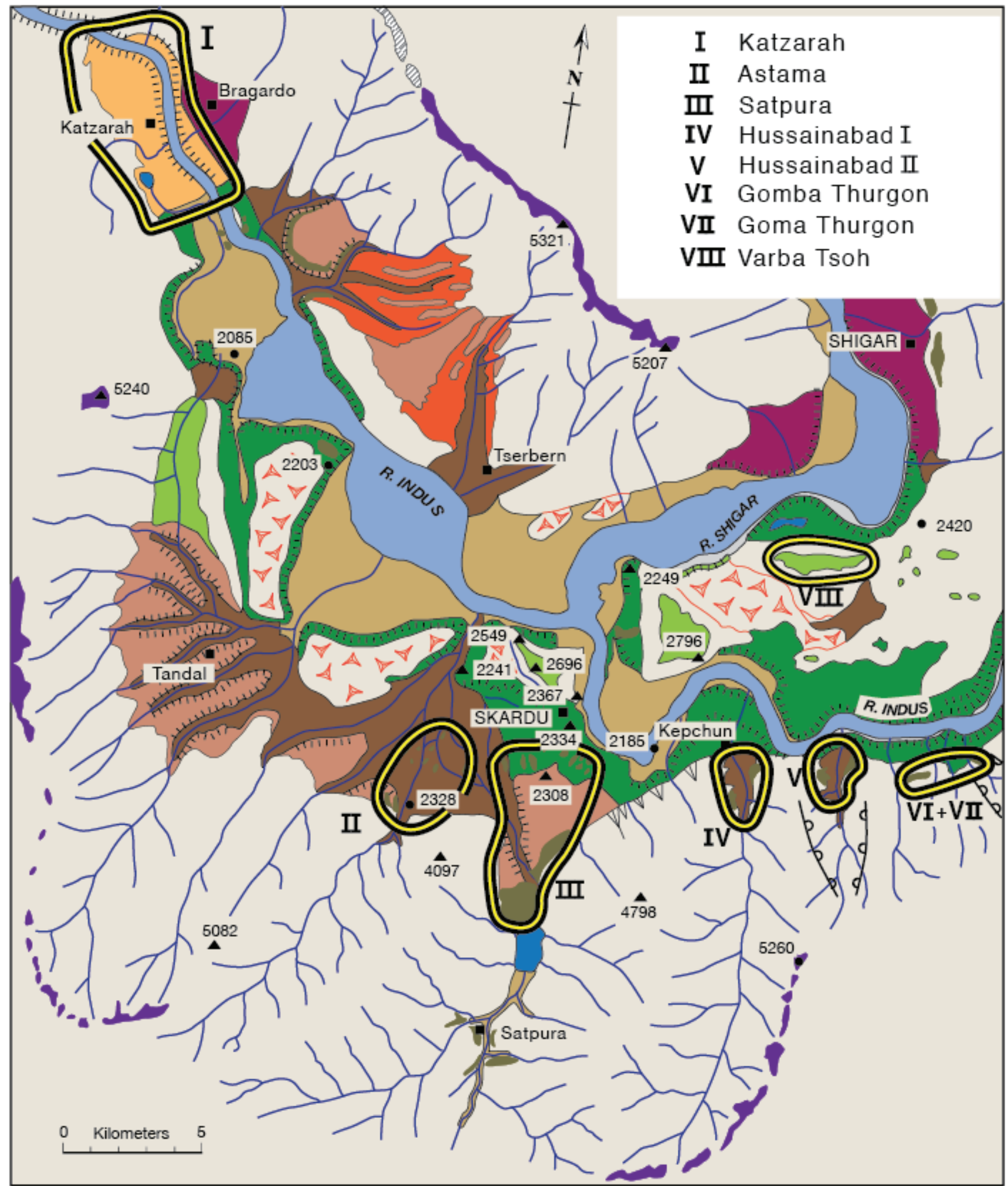

\section{KEY:}

\section{Till}

Recent floodplain sediments

Aeolian sand with rhoud dunes
Moranic fans

Recent debris-flows

Aluvial fan sediments
Lower terrace floodplain sediments Dominatly glaciofluvial sediments Hummocky moraine
Pre-Pleistocene planation surface

1 Scree
Early Pleistocene planation surface

Stream

Lake

In Catena surfaces

1111111 Terrace faces

- Triangulation point

- Spot height 

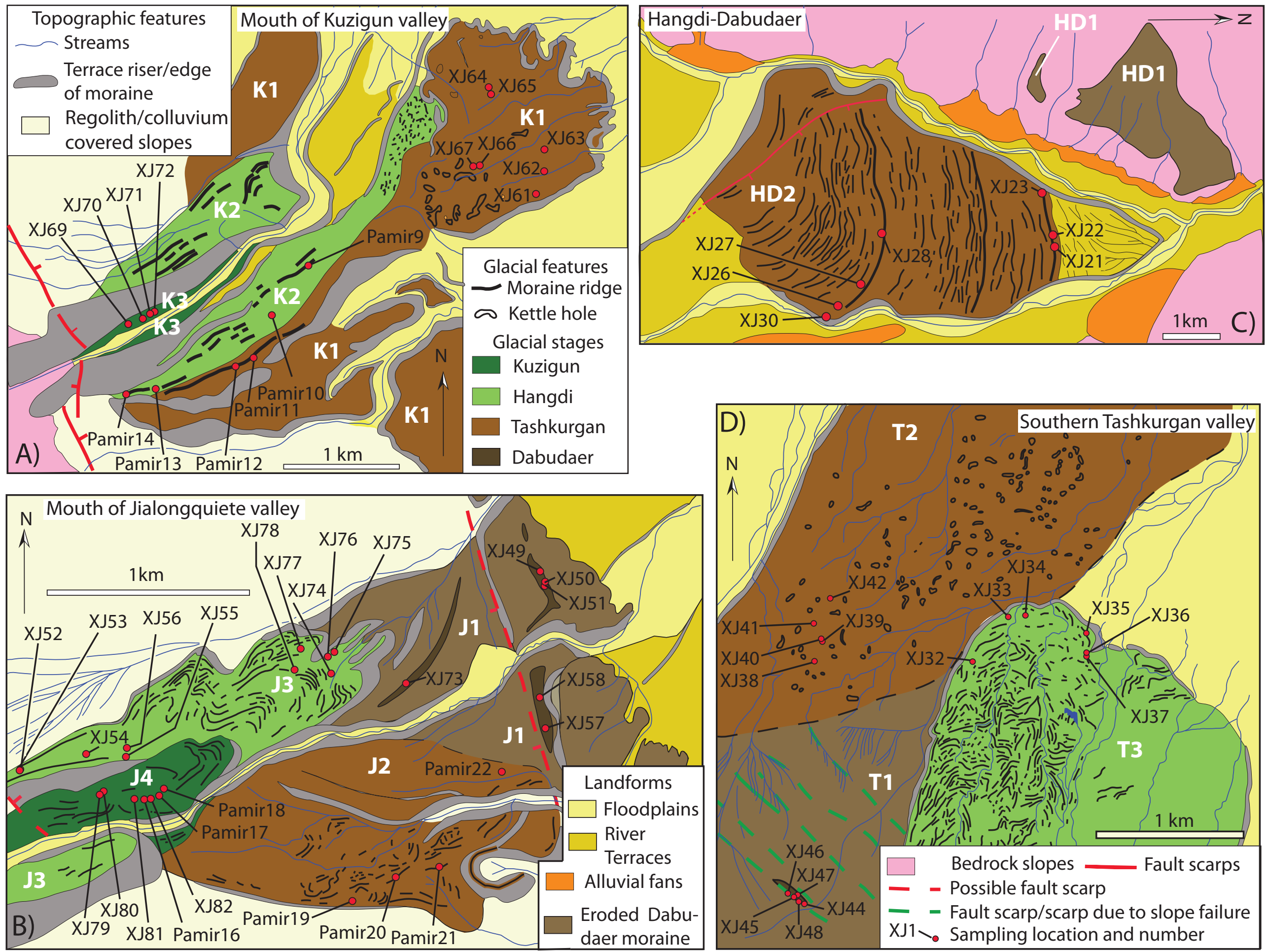

Figure 8 


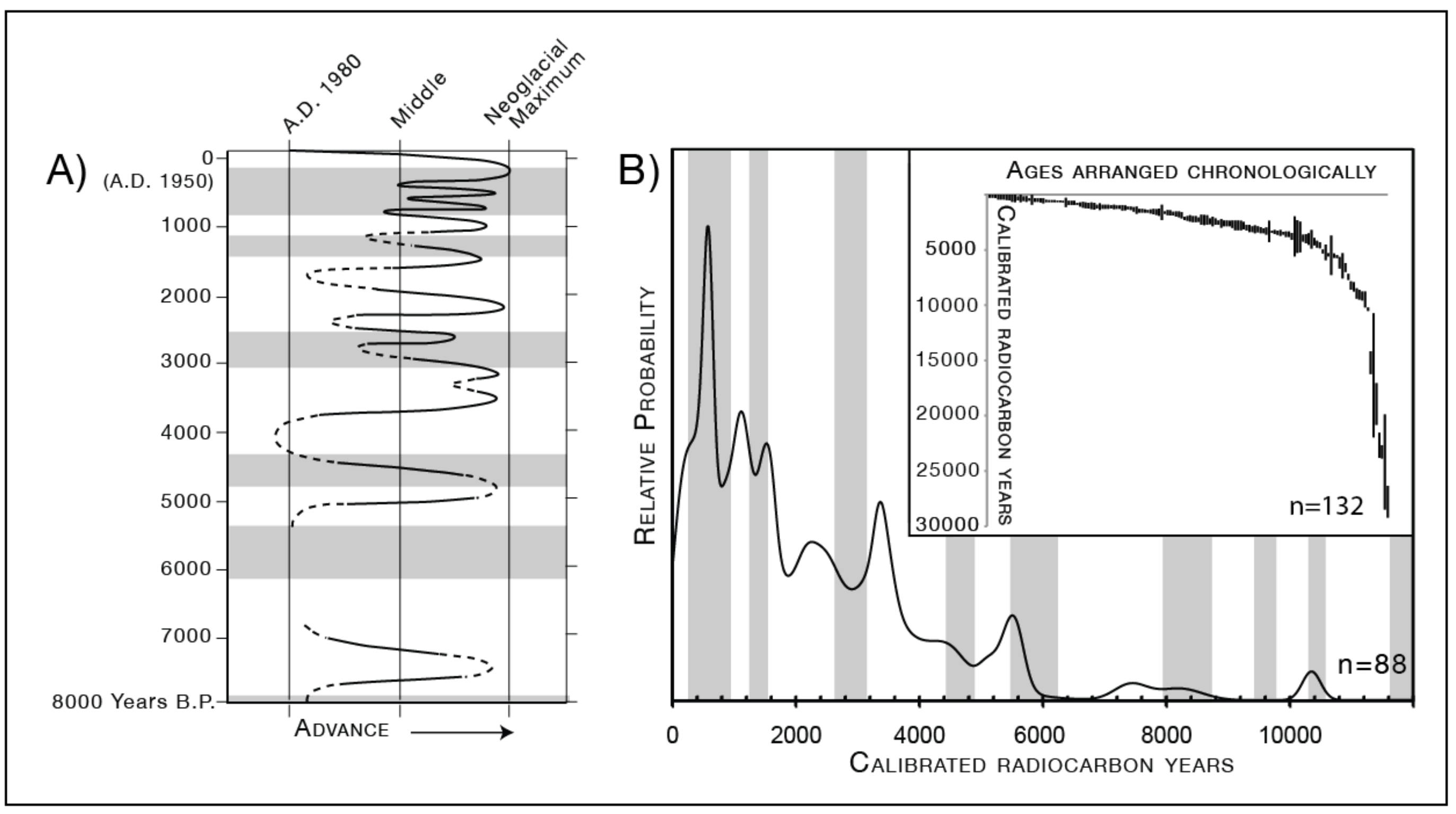

Figure 9 

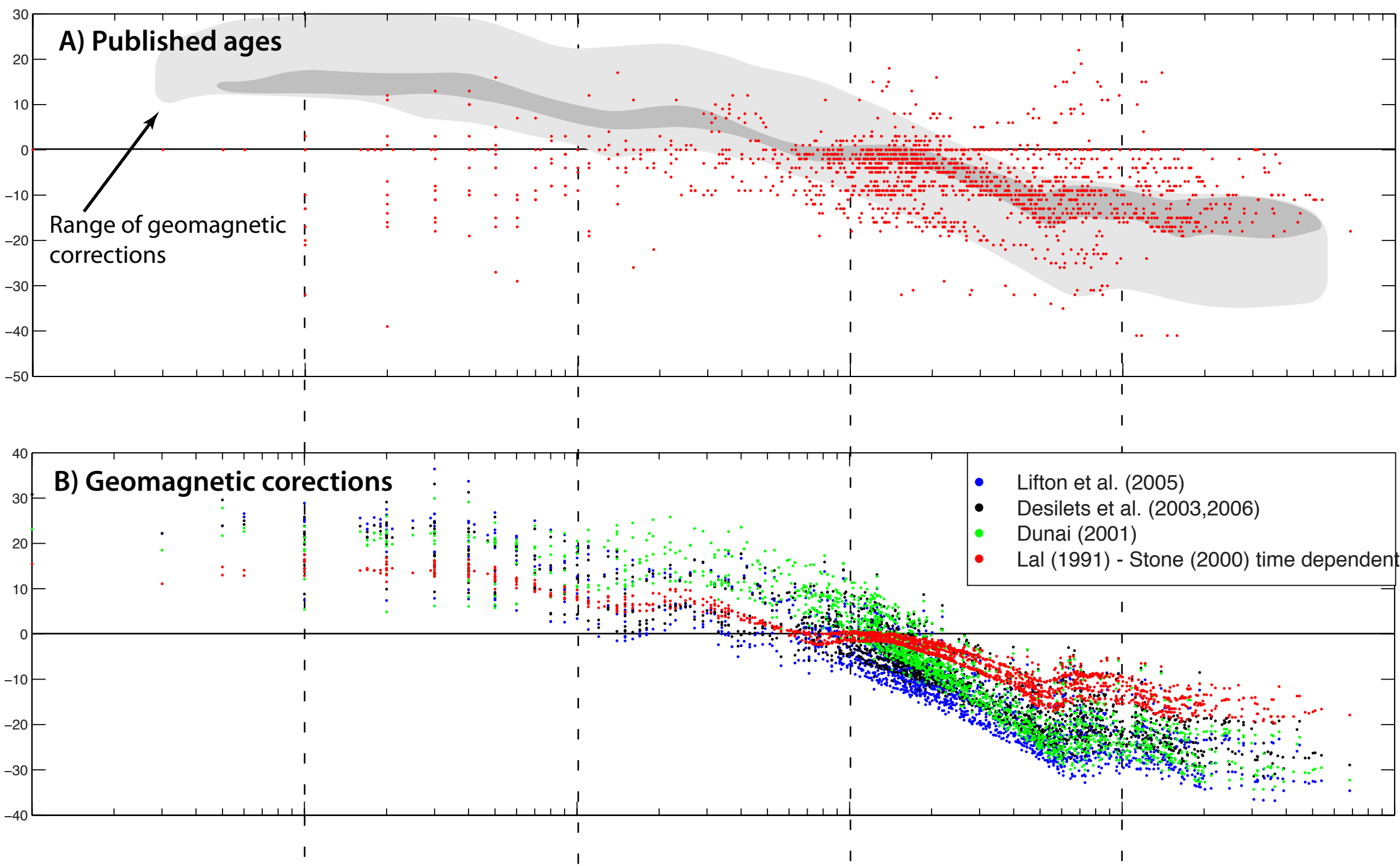

\section{C) Production rate changes}

- Balco et al. (2009) 3. $\$ 0.19$ at g $^{-1} \mathrm{yr}^{-1}$

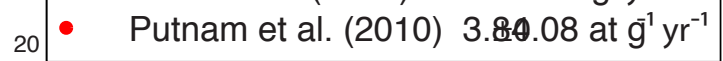
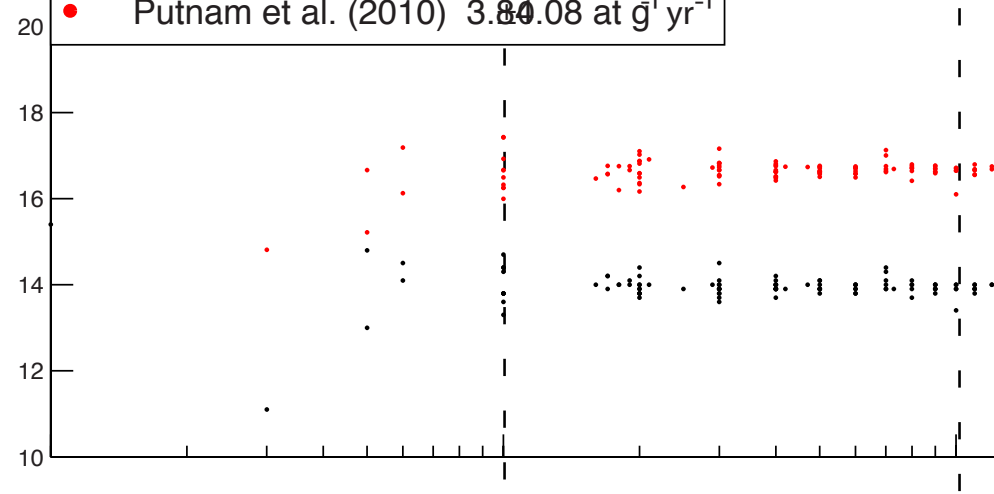

I

D) Combined production rate and geomagnetic correction
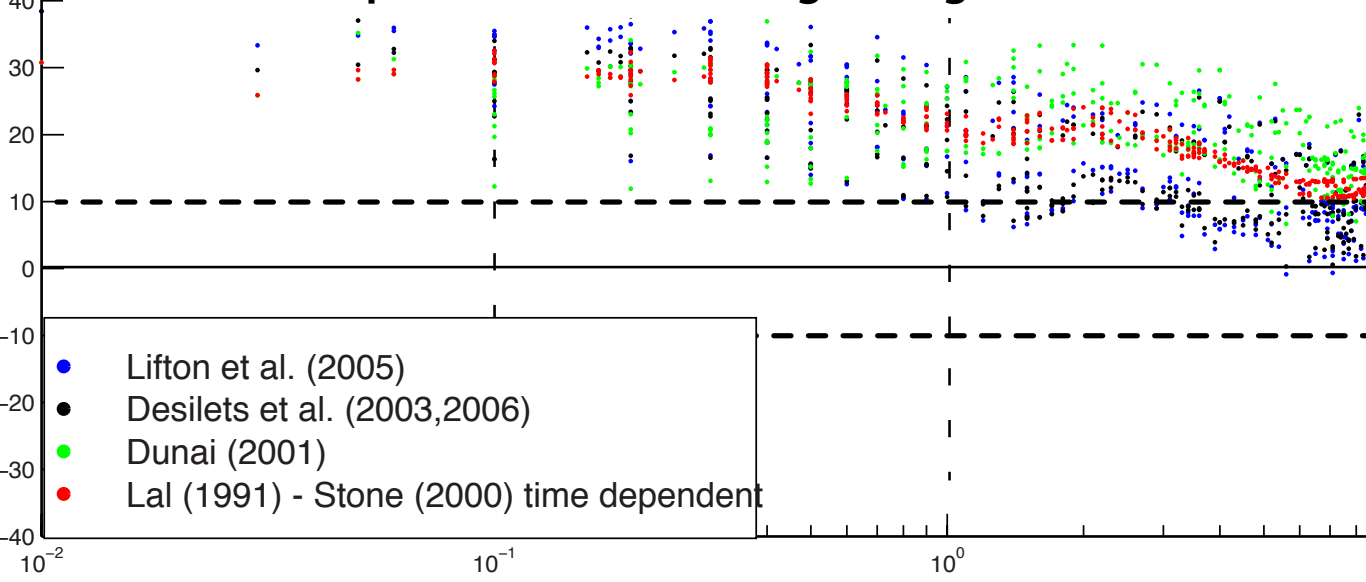

Lal/Stone time independent age (log ka) 


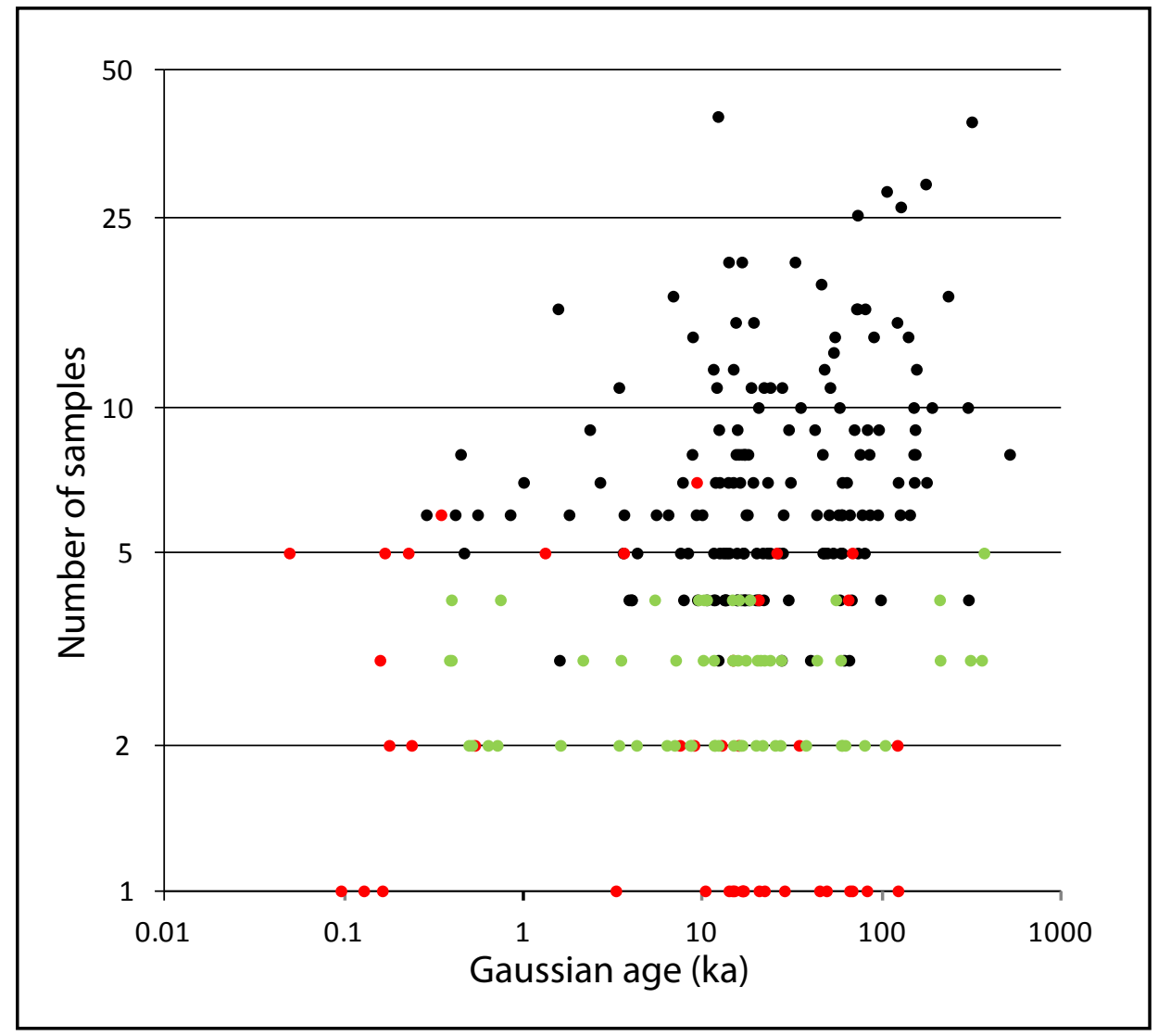

Figure 11 


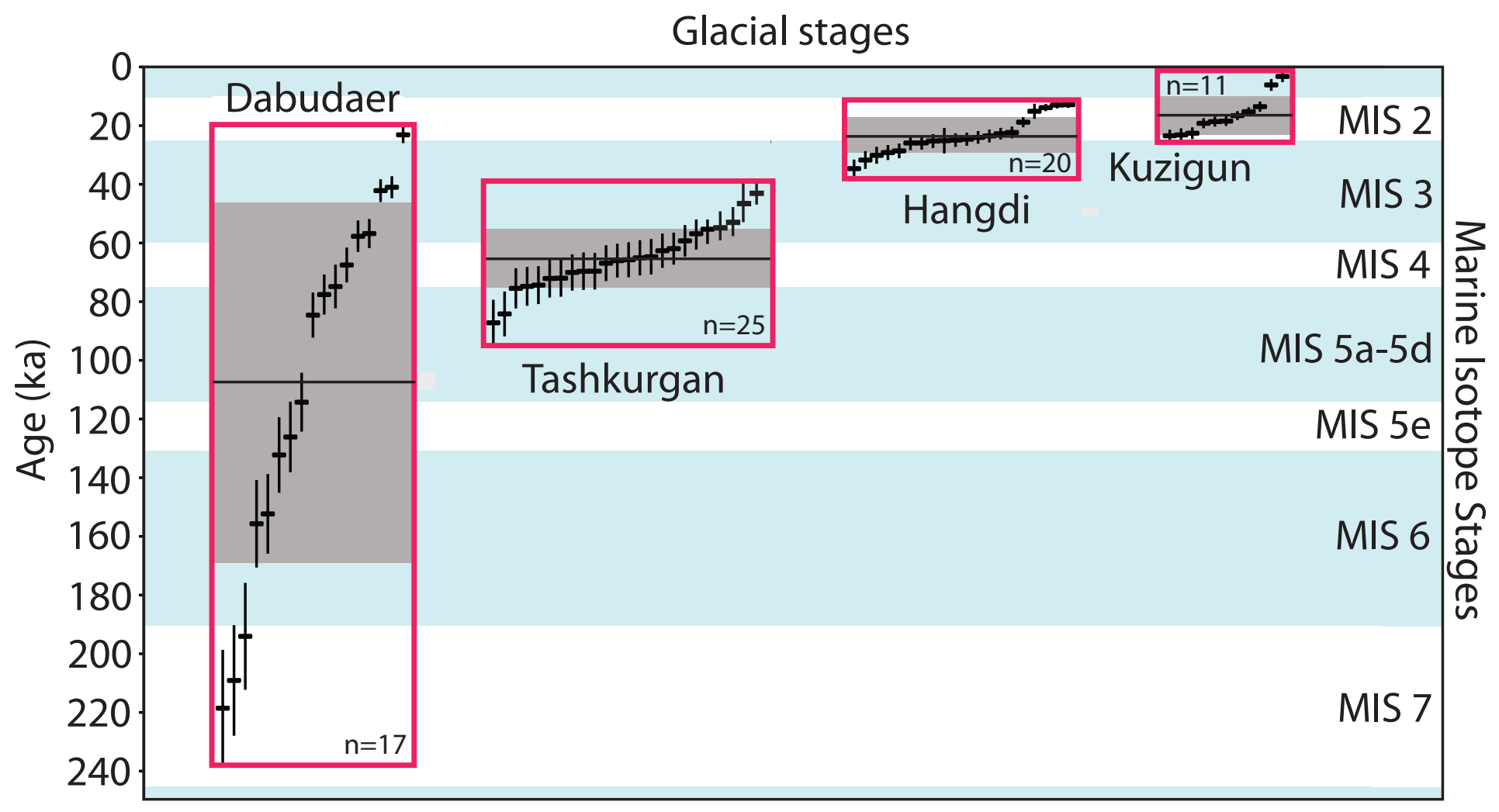

Figure 12 


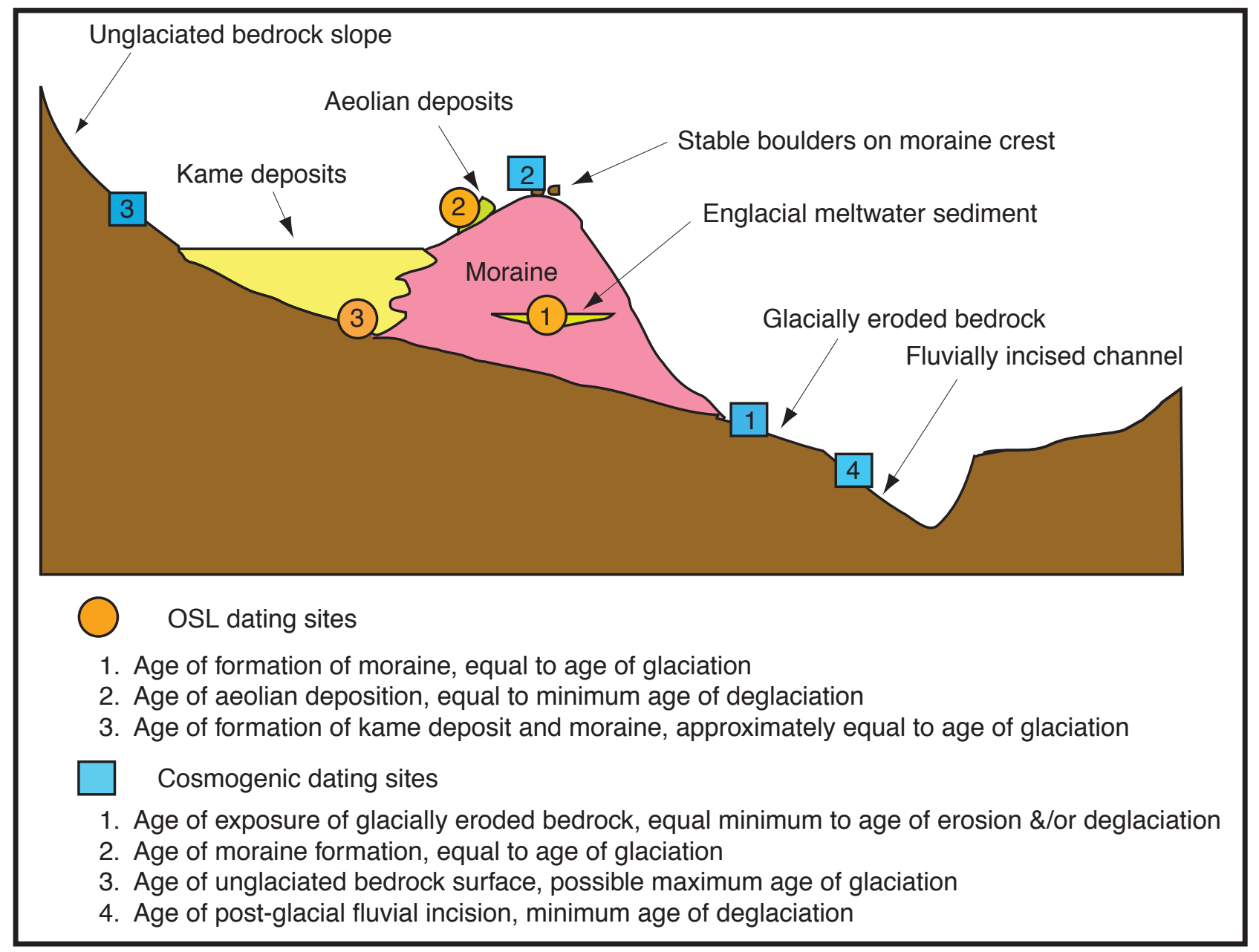

Figure 13 

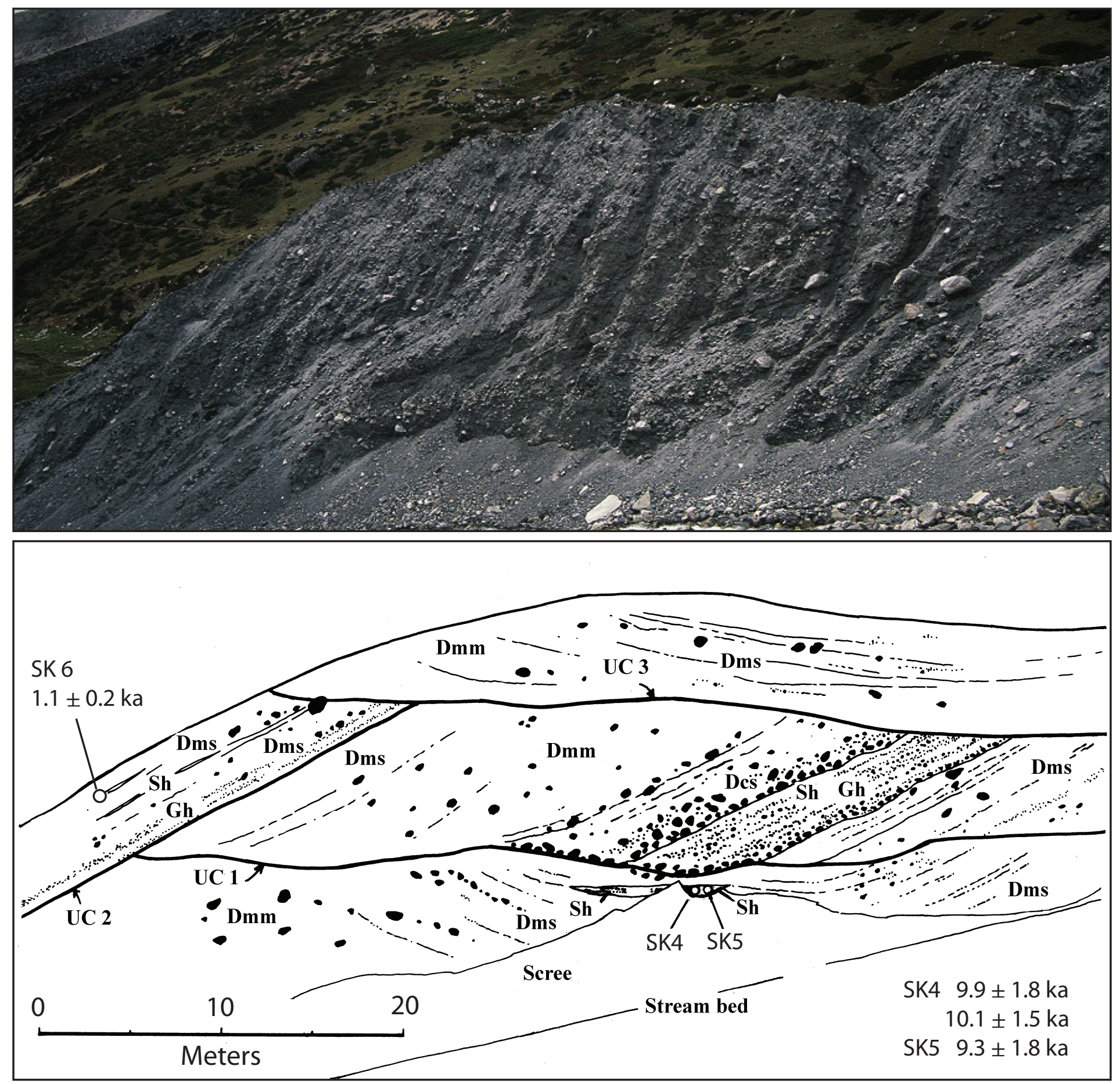

Figure 14 

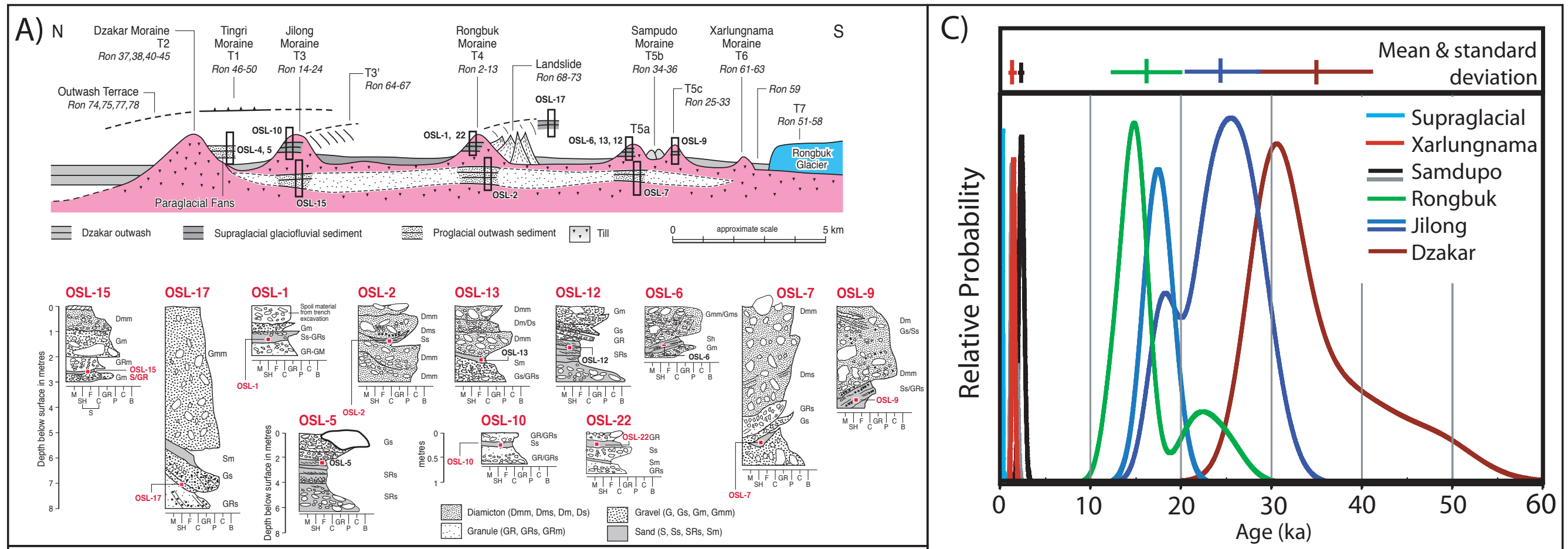

B)

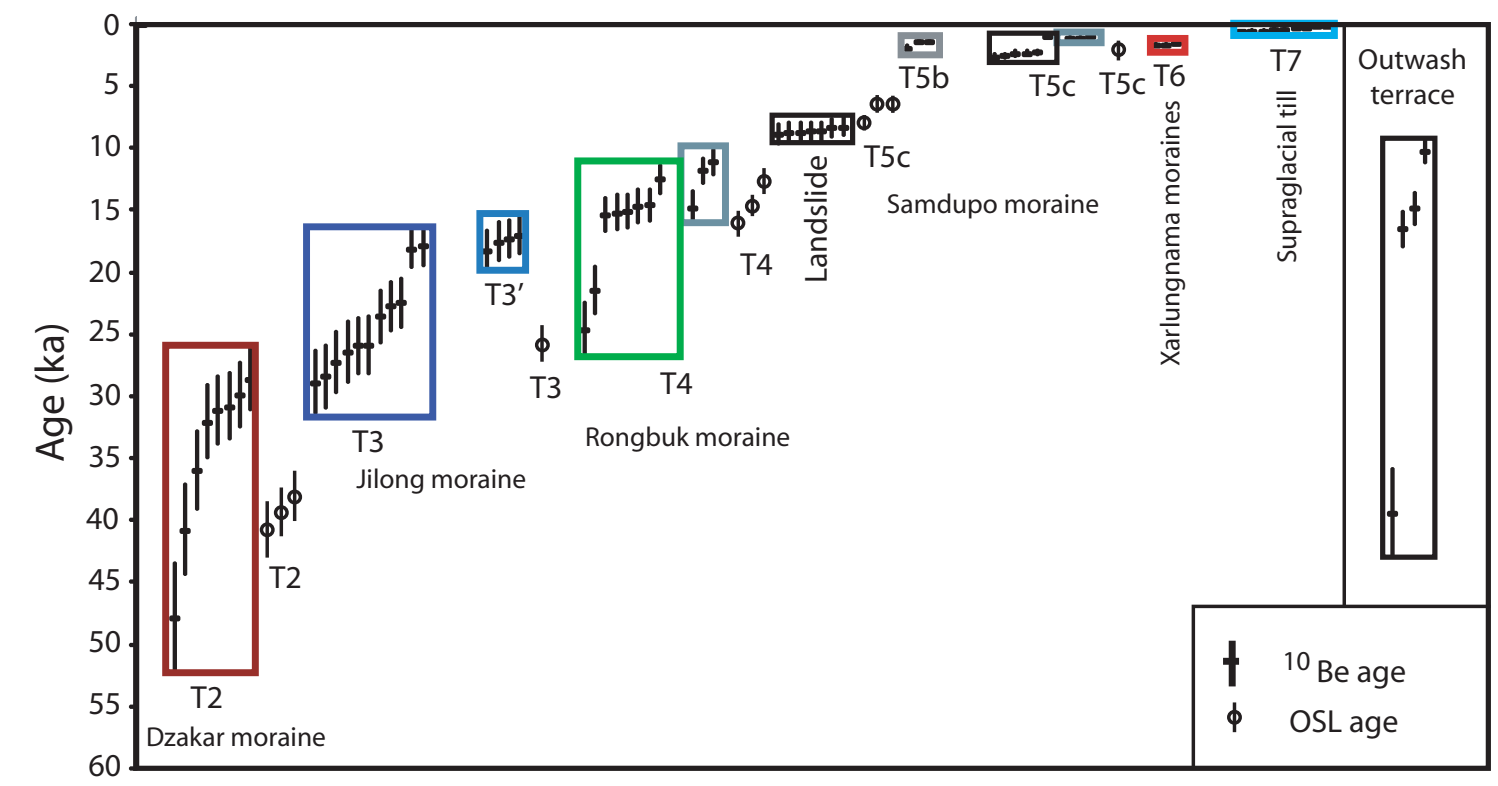

Relative Age

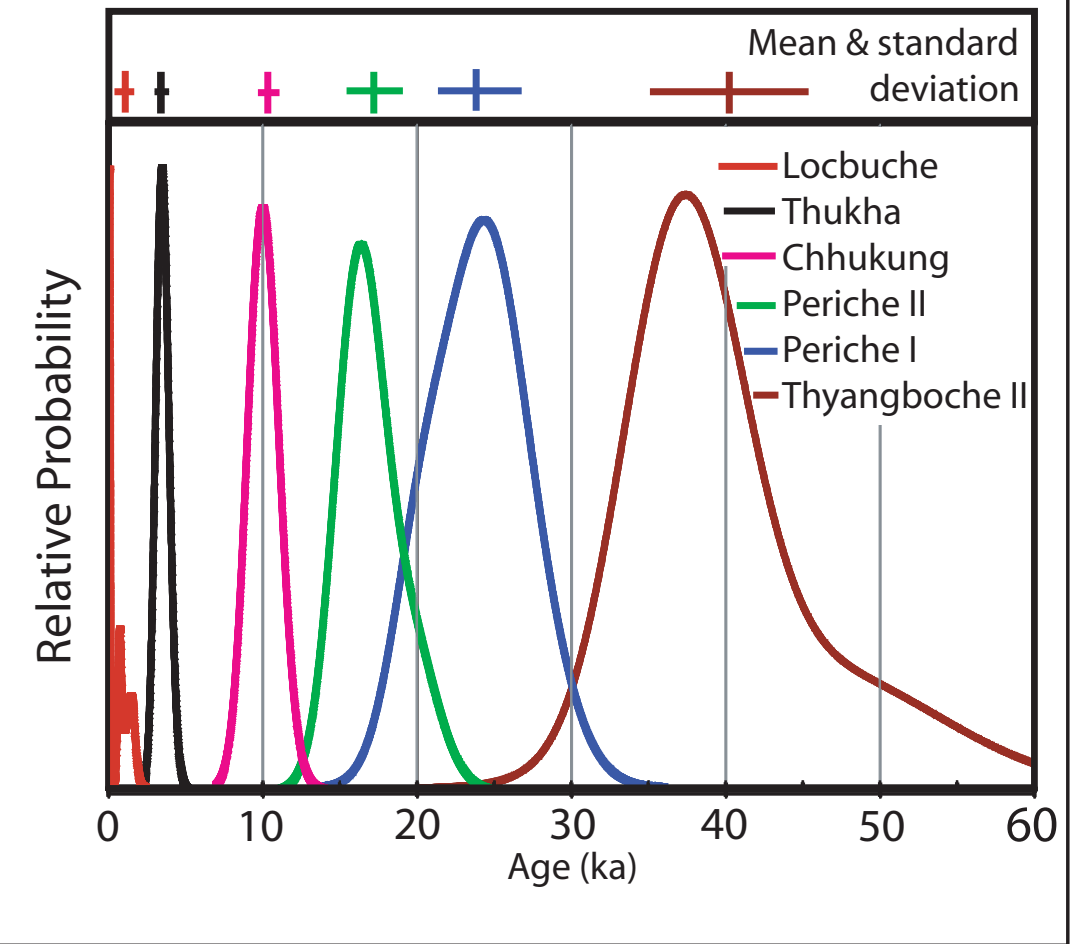

Figure 15 


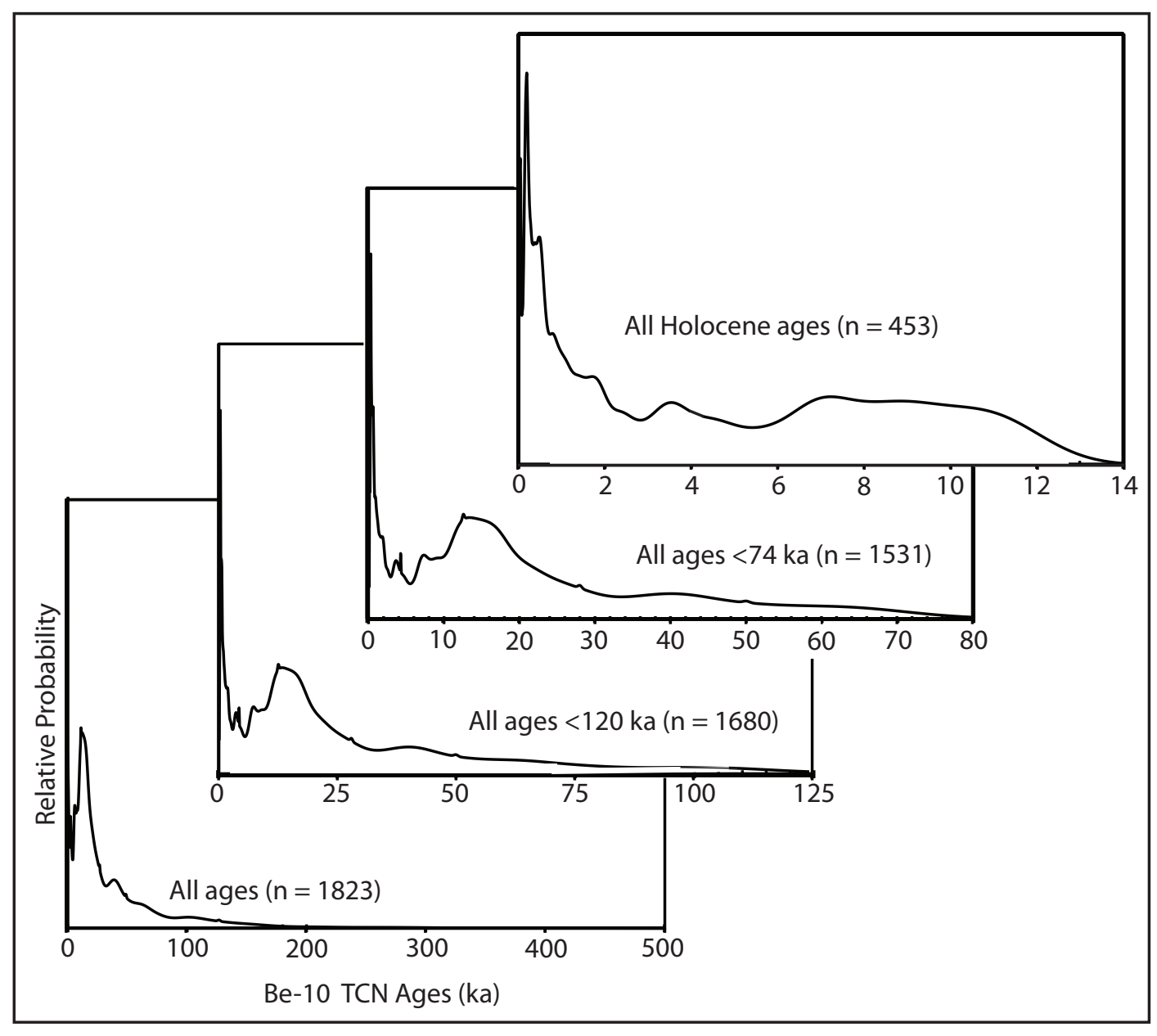

Figure 17

Figure 17 

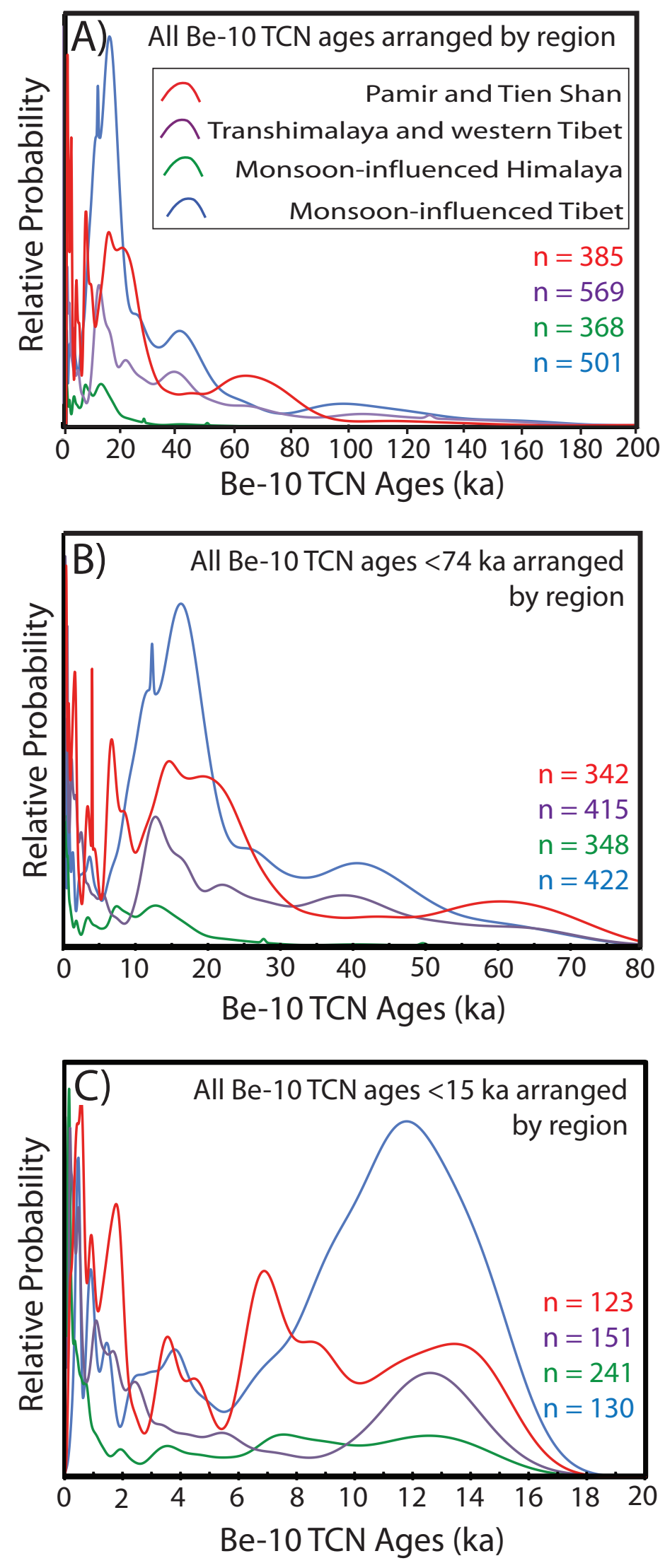

Figure 18 


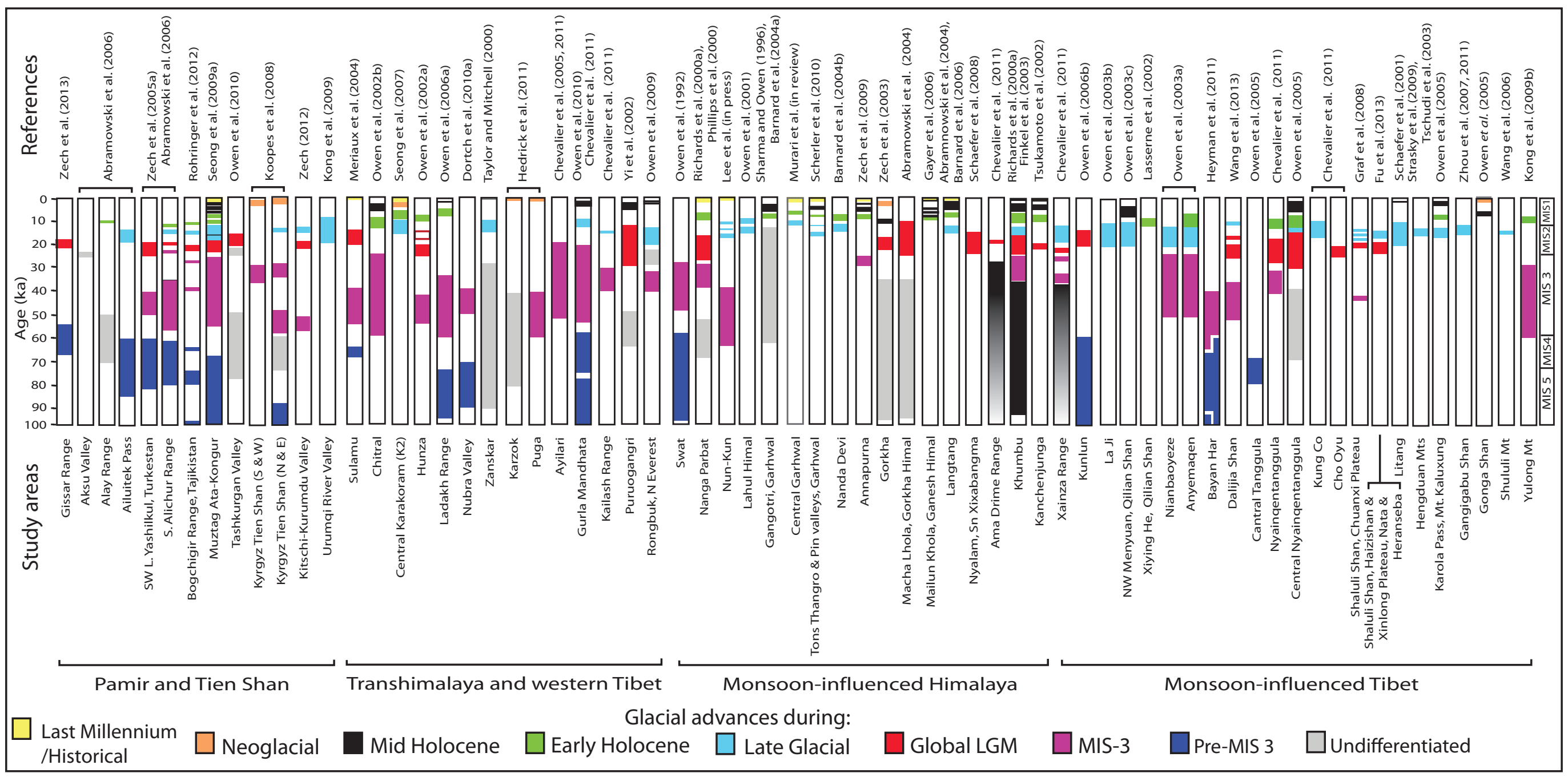

Figure 19 

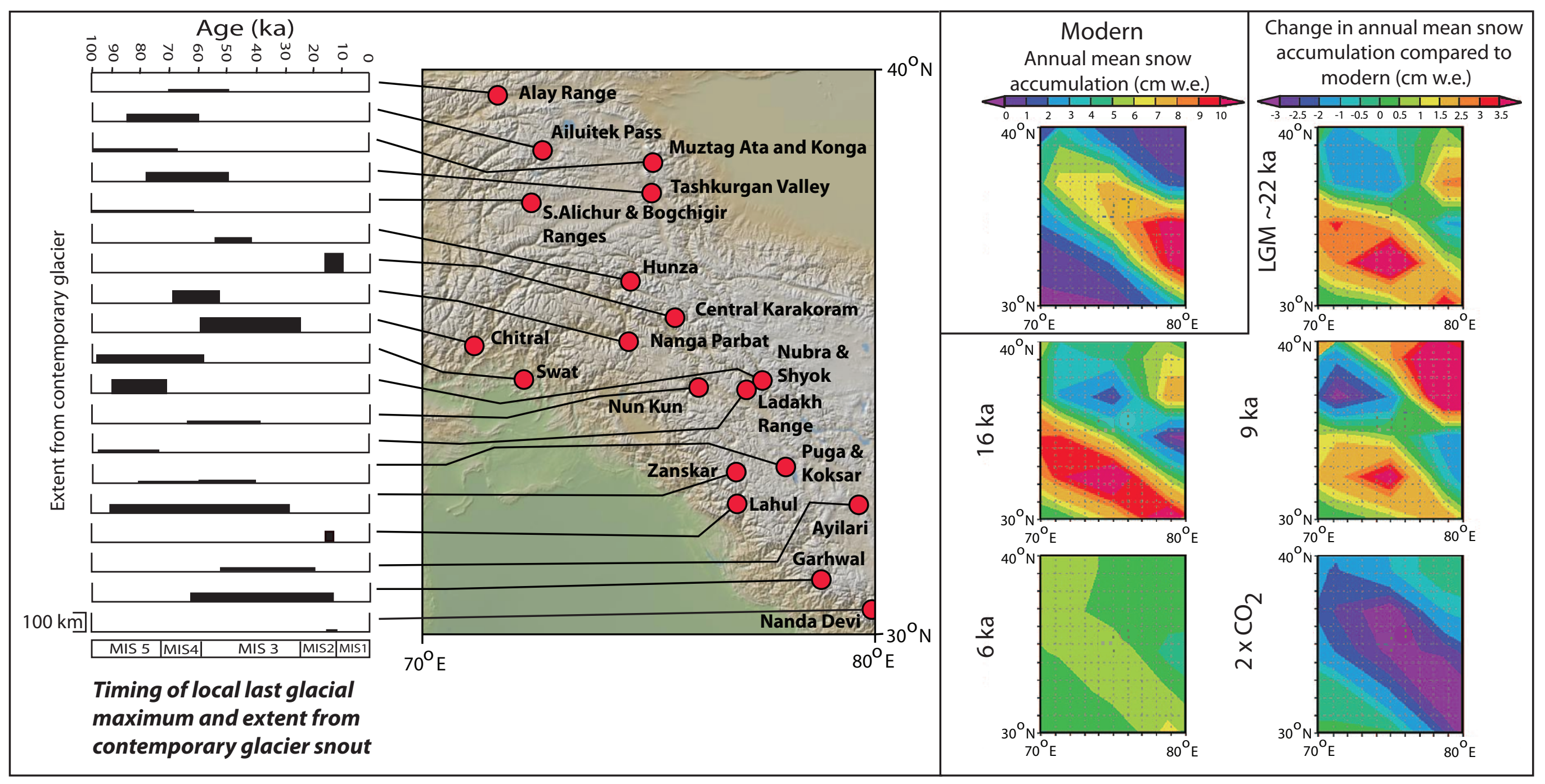

Figure 20 


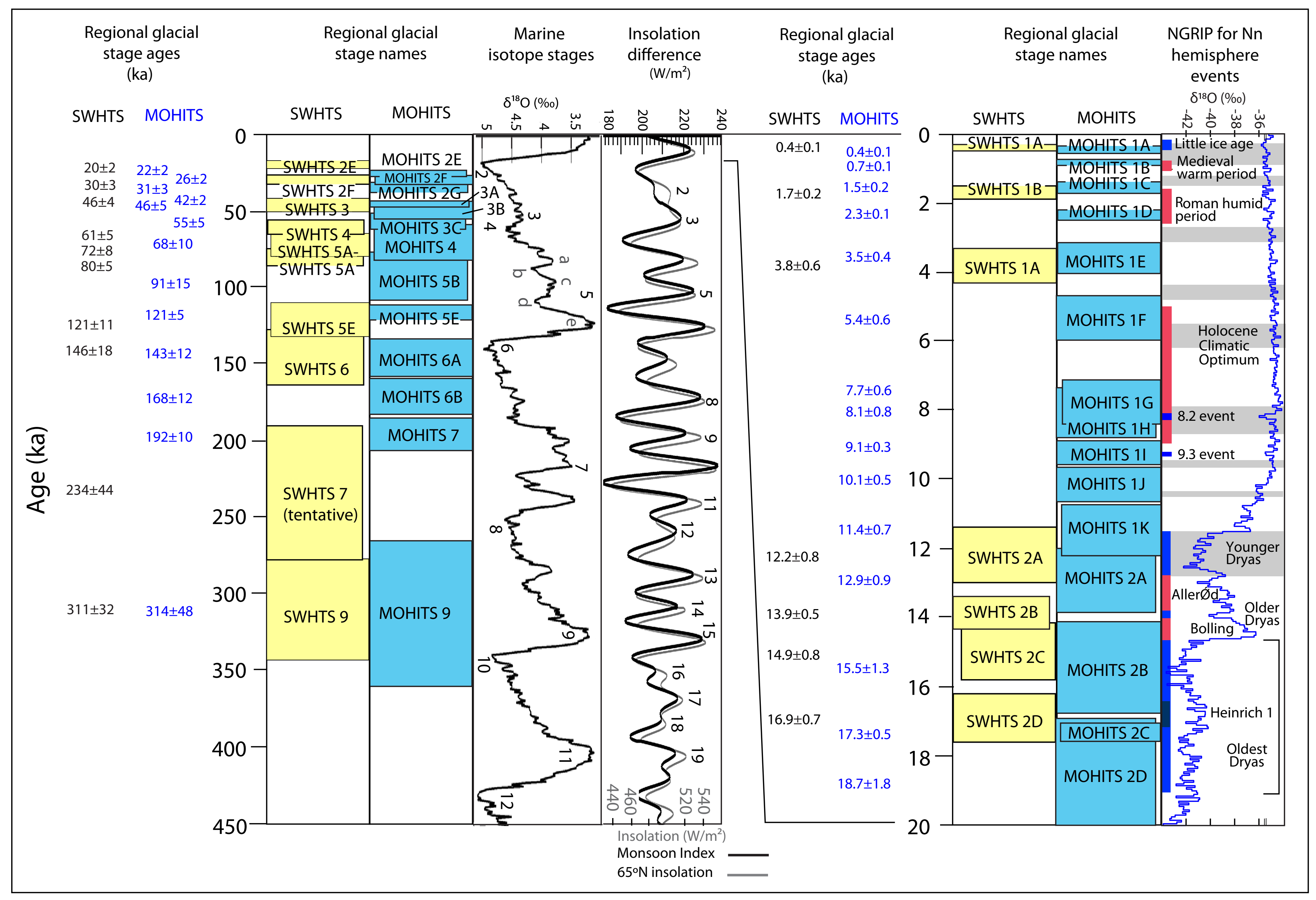

Figure 21 


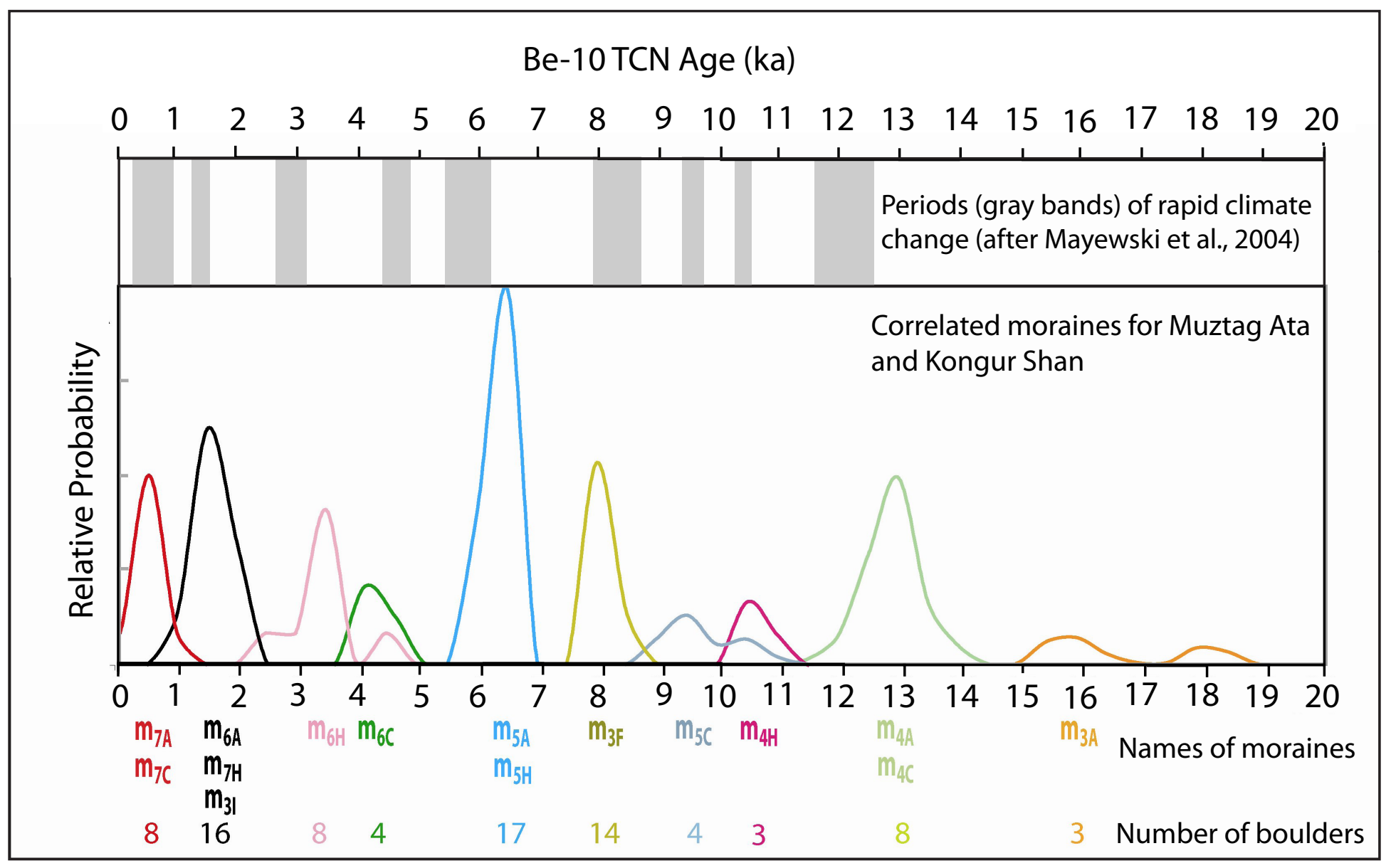

Figure 22 
Supplementary Data - Appendix 1
Click here to download Supplementary Data: Owen and Dortch_Appendix 1 Appendix 1.pdf

Supplementary Data - Appendix 1
Click here to download Supplementary Data: Owen and Dortch_Appendix 1 Appendix 1.pdf

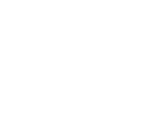
$\sqrt{10}$

(2)

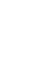

.

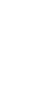

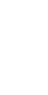

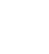
. 更 更 更 更 更 更 更 更 更 更 更 更 更 更 